Engineering Technology Division

NUCLEAR POWER PLANT CONTAINMENT METALLIC PRESSURE BOUNDARY MATERIALS AND PLANS FOR COLLECTING AND PRESENTING THEIR PROPERTIES

C. B. Oland

April 1995

Prepared for the

U.S. Nuclear Regulatory Commission

Office of Nuclear Regulatory Research

Under Interagency Agreement No. 1886-8604-3J

NRC JCN No. J6043

Prepared by the

OAK RIDGE NATIONAL LABORATORY

Oak Ridge, Tennessee 37831

managed by

MARTIN MARIETTA ENERGY SYSTEMS, INC.

for the

U.S. Department of Energy

under Contract No. DE-AC05-84OR21400 
TABLE OF CONTENTS

Page

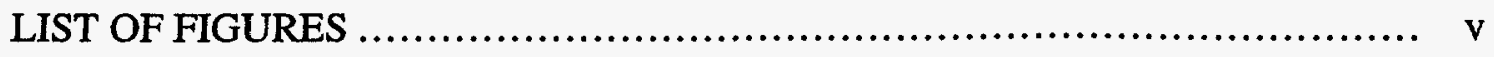

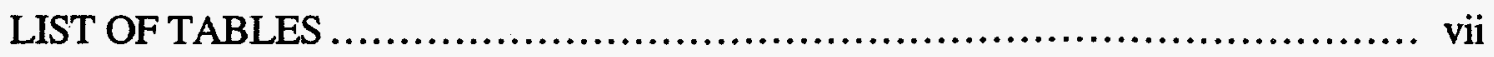

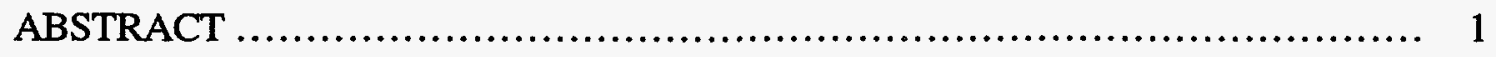

1. INTRODUCTION .......................................................... 1

1.1 BACKGROUND ................................................... 1

1.2 PURPOSE ......................................................... 1

1.3 STRUCTURAL MATERIALS INFORMATION CENTER ............... 2

1.4 PRESENTATION FORMATS............................................ 2

1.3.1 Structural Materials Handbook .................................. 2

1.3.2 Structural Materials Electronic Data Base ........................ 3

1.5 REFERENCES...................................................... 3

2. CONTAINMENT VESSEL PRESSURE BOUNDARIES........................... 7

2.1 CONCRETE AND METAL CONTAINMENT VESSELS................. 7

2.2 CONTAINMENT PRESSURE BOUNDARY STEELS........................ 8

2.3 POTENTIAL DEGRADATION MECHANISMS ......................... 8

2.3.1 Corrosion ................................................... 8

2.3.2 Fatigue ............................................................. 11

2.3.3 Neutron Irradiation..................................................... 12

2.3.4 Extreme Temperature Exposure .................................. 12

2.4 REFERENCES....................................................... 13

3. CLASSIFICATION AND DESIGNATION OF CONTAINMENT STEELS ...... 31

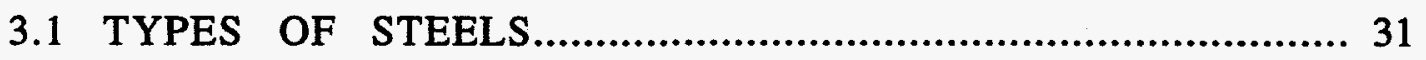

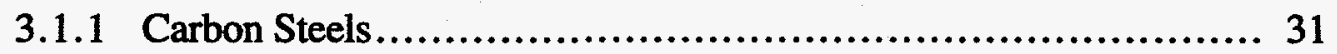

3.1.2 Low-Alloy Steels........................................................ 31

3.1.2 High-Alloy Steels .................................................. 32

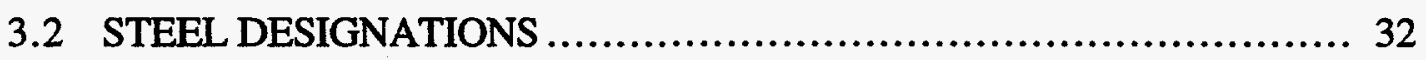

3.2.1 ASTM and ASME Material Specifications ........................ 32

3.2.2 Unified Numbering System (UNS)....................................... 33

3.2.2 Metal and Alloy Identification Standard .............................. 33

3.3 MATERIAL CODES ................................................. 34

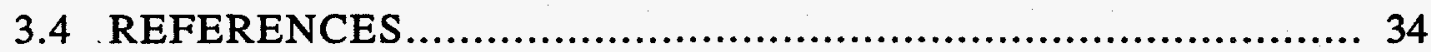

4. MATERIAL PROPERTIES AND DATA.......................................... 39

4.1 MECHANICAL PROPERTIES............................................. 39

4.1.1 Elastic Properties................................................ 39

4.1.2 Strength Properties......................................................... 40

4.1 .3 Fatigue Properties.............................................. 41 


\section{TABLE OF CONTENTS (cont.)}

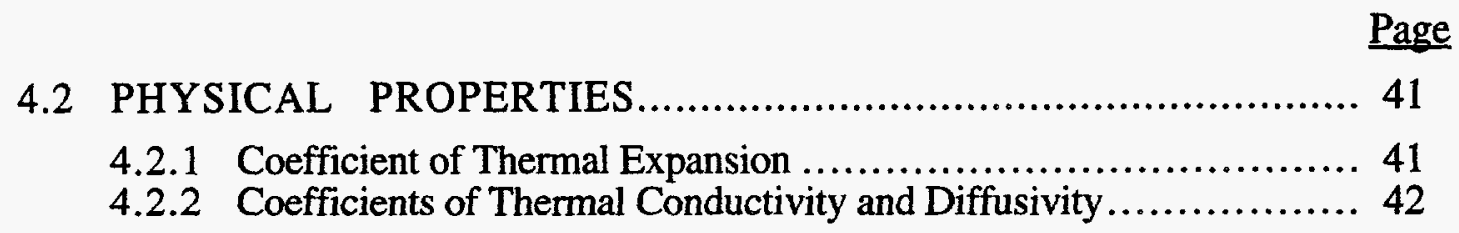

4.3 PROPERTY CODES ............................................. 42

4.3.1 General Information ............................................ 42

4.3.2 Mechanical Properties ......................................... 43

4.3.3 Thermal, Physical, and Other Properties............................ 43

4.4 REFERENCES......................................................... 43

5. PLAN FOR COLLECTING AND PRESENTING MATERIAL PROPERTIES... 51

5.1 DATA COLLECTION............................................. 51

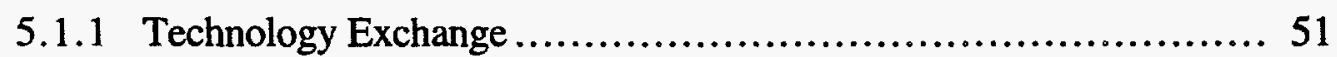

5.1.2 Prototypical Material Procurement .................................. 51

5.1 .3 Accelerated Aging Tests....................................... 52

5.2 DATA BASE PRESENTATION.......................................... 52

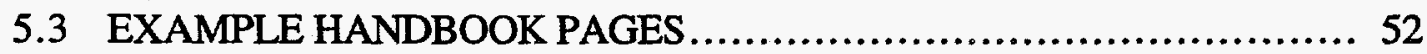

5.4 REFERENCES........................................................ 53

6. SUMMARY ................................................................. 69

6.1 STEELS PERMITTED FOR CONTAINMENT CONSTRUCTION ........ 69

6.2 CONTAINMENT STEEL DEGRADATION................................. 69

6.3 PROPOSED ACTIVITIES............................................. 69

6.4 REFERENCES ..................................................... 70

APPENDIX: EXAMPLE STRUCTURAL MATERIALS HANDBOOK PAGES

FOR ASME SA-36 CONTAINMENT STEEL ........................ 73 


\section{LIST OF FIGURES}

Figure

Page

2.1 PWR subatmospheric concrete containment configuration

2.2 BWR Mark I metal containment configuration ......................... 16

2.3 BWR Mark II metal containment configuration ........................ 17

2.4 BWR Mark III metal containment configuration ....................... 18

2.5 PWR spherical metal containment configuration........................ 19

2.6 PWR cylindrical metal containment configuration ....................... 20

2.7 PWR cylindrical ice-condenser metal containment configuration ............ 21 .

3.1 Material code arrangement for containment steels.......................... 36

\section{DISCLAIMER}

This report was prepared as an account of work sponsored by an agency of the United States This report was prepared as an account of work sponsored by an ageacy of thereof, not any of their employees, makes any warranty, express or implied, or assumes any legal liability or responsibility for the accuracy, completeness, or usefulness of any information, apparatus, product, or process disclosed, or represents that its use would not infringe privately owned rights. Reference herein to any specific commercial product, process, or service by trade name, trademark, manufacturer, or otherwise does not necessarily constitute or imply its endorsement, recommendation, or favoring by the United States Government or any agency thereof. The views and opinions of authors expressed herein do not necessarily state or reflect those of the United States Government or any agency thereof. 
, 


\section{DISCLAIMER}

Portions of this document may be illegible in electronic image products. Images are produced from the best available original document. 


\section{LIST OF TABLES}

Table

1.1 Containment steel data and information requirements $\ldots \ldots \ldots \ldots \ldots \ldots \ldots \ldots .5$

2.1 Material specifications permitted for construction of metal containments ... 22

2.2 Material specifications permitted for bolting materials....................... 25

2.3 Material specifications permitted for construction of concrete containment liners ............................................ 26

2.4 Material specifications permitted for reinforcing bar splice sleeves attached to concrete containment liners................................... 27

$2.5 \quad$ Types and forms of corrosion........................................ 28

2.6 Aqueous environments that could potentially cause stress-corrosion cracking of containment steels............................................ 29

3.1 Chemical elements that are sometimes present in containment steels ........ 37

Class indexes for containment steels ................................. 38

4.1 Material property code ranges and descriptions ....................... 46

4.2 General information property codes .................................. 47

4.3 Property codes for mechanical property values of containment steels....... 48

4.4 Property codes for mechanical property graphs and plots for containment steels.

5.1 Steels used to construct metal and concrete containment pressure boundary components.

5.2 Carbon and low-alloy steel plates, shapes, and bars permitted for use in construction of containment pressure boundary components.

5.3 Carbon and low-alloy steel forgings and castings permitted for use in construction of containment pressure boundary components.

5.4 Carbon and low-alloy steel pipes, tubes, and fittings permitted for use in construction of containment pressure boundary components.

5.5 Carbon and low-alloy steel bolting materials permitted for use in construction of containment pressure boundary components.

5.6 Carbon and low-alloy steel special materials permitted for use in construction of containment pressure boundary components. 


\section{LIST OF TABLES (cont.)}

Table

Page

5.7 Stainless steel plates and bars permitted for use in construction of containment pressure boundary components........................ 62

5.8 Stainless steel forgings and castings permitted for use in construction of containment pressure boundary components

5.9 Stainless steel pipes, tubes, and fittings permitted for use in construction of containment pressure boundary components ............................

5.10 Stainless steel bolting materials permitted for use in construction of containment pressure boundary components ......................... 68

6.1 Degradation mechanisms that could potentially affect containment steels... 71 


\title{
NUCLEAR POWER PLANT CONTAINMENT METALLIC PRESSURE BOUNDARY MATERIALS AND PLANS FOR COLLECTING AND PRESENTING THEIR PROPERTIES
}

\author{
C. B. Oland \\ D. J. Naus
}

\begin{abstract}
A program is being conducted at the Oak Ridge National Laboratory (ORNL) to assist the Nuclear Regulatory Commission (NRC) in their assessment of the effects of degradation (primarily corrosion) on the structural capacity and leaktight integrity of metal containments and steel liners of reinforced concrete structures in nuclear power plants. One of the program objectives is to characterize and quantify manifestations of corrosion on the properties of steels used to construct containment pressure boundary components. This report describes a plan for use in collecting and presenting data and information on ferrous alloys permitted for use in construction of pressure retaining components in concrete and metal containments. Discussions about various degradation mechanisms that could potentially affect the mechanical properties of these materials are also included. Conclusions and recommendations presented in this report will be used to guide the collection of data and information that will be used to prepare a material properties data base for containment steels.
\end{abstract}

\section{INTRODUCTION}

\subsection{BACKGROUND}

Approximately 110 boiling-water (BWR) and pressurized-water (PWR) nuclear power plants are licensed by the Nuclear Regulatory Commission (NRC) to operation in the United States. In some cases, two or more plants are located at a particular site. Each plant includes either a concrete or metal containment that is designed to prevent the release of radioactive fission products into the environment under postulated design basis accident conditions. Containments for BWR plants are constructed predominantly from steel using either pre-Mark, Mark I, Mark II, or Mark III designs. PWR plants use either large dry, ice condenser, or sub-atmospheric containments that are constructed predominantly using either reinforced or post-tensioned concrete. Although a wide variety of containment geometries have been used for BWR and PWR plants, in all cases, leaktightness is ensured by a continuous pressure boundary consisting primarily of steel components that are either welded or bolted together.

\subsection{PURPOSE}

A program is being conducted at the Oak Ridge National Laboratory (ORNL) to assist the NRC in their assessment of the effects of degradation (primarily corrosion) on the structural capacity and leaktight integrity of metal containments and steel liners of reinforced concrete structures in nuclear power plants. One of the objectives of this research program is to characterize and quantify manifestations of corrosion on the properties of steels used to construct containment 
pressure boundary components. This report describes a plan for use in collecting and presenting data and information on steels permitted by the American Society of Mechanical Engineers (ASME) Boiler and Pressure Vessel Code (Refs. 1.1 and 1.2) for use in construction of pressure retaining components in concrete and metal containments. Discussions about various degradation mechanisms that could potentially affect the mechanical properties of these materials are also included. Conclusions and recommendations presented in this report will be used to guide the collection of data and information that will be used to prepare a material properties data base for containment steels.

\subsection{STRUCTURAL MATERIALS INFORMATION CENTER}

A Structural Materials Information Center was established at ORNL to prepare a data base of long-term and environment-dependent properties for portland cement concretes, metallic reinforcements, prestressing tendon materials, and structural steels used to construct buildings and safety-related structures in nuclear power plants (Ref. 1.3). A report that summarizes the materials contained in the data base has been published (Ref. 1.4). Under the steel containment and liners program, this data base will be expanded to include steels used to construct containment pressure boundary components. Data and information about containment steels and their properties will be collected from open-literature reports and published references. Technical information exchanges with material producers and research organizations will also be pursued to supplement the existing reference materials. Whenever possible, results from prototypical material sample tests will be accumulated and compiled. Table 1.1 shows data and information requirements that will be used to identify containment steel properties considered suitable for entry into the data base.

\subsection{PRESENTATION FORMATS}

Data and information that are considered suitable for entry into the data base will be assembled and presented in two complementary formats (Ref. 1.5). The Structural Materials Handbook is an expandable, hard-copy reference document that contains the complete data base for each material. The Structural Materials Electronic Data Base is accessible using an IBM-compatible personal computer and provides an efficient means for searching the various data base files to locate materials with common properties and similar characteristics. Properties will be reported in the handbook and the electronic data base using the International System of Units (SI) and in customary units whenever possible (Ref. 1.6).

\subsubsection{Structural Material Handbook}

The Structural Materials Handbook consists of four volumes that are published in looseleaf binders. Volume 1 contains performance values that can be used to compare material behavior and to estimate material properties under the influence of environmental stressors and aging factors. Volume 2 contains documentation that supports the performance values reported in Volume 1. Performance values are presented graphically and mathematically in both of these volumes as performance curves. Volume 3 contains material data sheets that can be used to report general information and baseline data as well as material specifications such as provided by the American Society of Testing and Materials (ASTM) under which the material was produced. Volume 4 contains appendices that provide documentation and reference information for the handbook and the electronic data base. Appendix A contains handbook organization and updating information, Appendix B describes material codes, Appendix C lists property codes, property code abbreviations, and units, Appendix D provides quality level criteria used to evaluate data and values, Appendix $\mathrm{E}$ includes references, and Appendix F contains electronic data base user information. 
Data and information reported in Volumes 1,2, and 3 of the handbook are organized into chapters. Each chapter corresponds to a particular type or category of material. Properties for containment steels will be presented in Chapter 6 . Volumes 1,2, and 3 of the handbook serve as the information source for the electronic data base.

\subsubsection{Structural Material Electronic Data Base}

The Structural Materials Electronic Data Base is an electronically accessible version of the Structural Materials Handbook. The data base will be developed on a personal computer using a commercially available data base management system of software available from ASM INTERNATIONAL, Materials Park, Ohio. The software includes two programs - Mat.DB (Ref. 1.7) and EnPlot (Ref. 1.8) - designed specifically for maintaining and displaying properties of engineering materials. The user's manuals provided with the software include specific instructions for formatting, entering, searching, and displaying data and information.

Mat.DB and EnPlot operate on an IBM-compatible personal computer using DOS 3.0 or later. As a minimum, the computer must have $640 \mathrm{~K}$ of memory, a hard disk, a graphics card, and a monitor. Details about other hardware configurations are provided in the user's manuals. Mat.DB is a menu-driven program that employs window overlays to access data searching and editing features. This software is capable of maintaining, searching, and displaying textual, tabular, and graphical information and data contained in electronic data base files. Mat.DB was developed for metallic materials, but can accommodate nonmetallic and composite materials. The instructions in the user's manual provide procedures for entering data and information into electronic data base files and for customizing presentation formats. EnPlot incorporates pop-up menus for creating and editing engineering graphs. This software includes curve-fitting and scale-conversion features for preparing engineering graphs and utility features for generating output files. The engineering graphs that appear in the electronic data base files and the graphs that appear in Volumes 1 and 2 of the handbook will be prepared using this software. The electronic data base file that contains containment steels will be named CONTAIN.DB.

\subsection{REFERENCES}

1.1 "Rules for Construction of Nuclear Power Plant Components," ASME Boiler and Pressure Vessel Code, Section III, Division 2, Code for Concrete Reactor Vessels and Containments, Subsection CC, Concrete Containments (Prestressed or Reinforced), American Society of Mechanical Engineers, New York, New York, July 1, 1992.

1.2 "Rules for Construction of Nuclear Power Plant Components," ASME Boiler and Pressure Vessel Code, Section III, Division 1 - Subsection NE, Class MC Components, American Society of Mechanical Engineers, New York, New York, July 1, 1992.

1.3 Oland, C. B. , Marchbanks, M. F., and Naus, D. J., Plan for Use in Development of the Structural Materials Information Center, ORNL/LTR-89/8, Martin Marietta Energy System, Inc., Oak Ridge National Laboratory, Oak Ridge, Tennessee, September, 1989.

1.4 Oland, C. B. and Naus, D. J., Summary of Materials Contained in the Structural Materials Information Center, ORNL/LTR-94/22, Martin Marietta Energy System, Inc., Oak Ridge National Laboratory, Oak Ridge, Tennessee, November 1994.

1.5 Oland, C. B. and Naus, D. J., Structural Materials Information Center for Presentation of the Time Variation of Material Properties, ORNL/NRC/LTR-90/22, Martin Marietta Energy System, Inc., Oak Ridge National Laboratory, Oak Ridge, Tennessee, November 1990. 
1.6 "Standard Practice for Use of the International System of Units (SI) (the Modernized Metric System)," ASTM Designation: E 380-92, American Society for Testing and Materials, Philadelphia, Pennsylvania, October 1992.

1.7 Mat.DB, Version 1.22, ASM International, ASM/Center for Materials Data, Materials Park, Ohio, 1992.

1.8 EnPlot, Version 3.5, ASM International, ASM/Center for Materials Data, Materials Park, Ohio, 1993. 
Table 1.1 Containment steel data and information requirements.

\section{GENERAL INFORMATION}

Background, Scope, and Objectives

Material Description

Processing Information

Baseline Data

Reference Sources
Identify the construction project and the steel application, or provide a description of the test or research program for which the steel was obtained. Identify the test parameters and include a description of the test specimens. Identify the testing methods and conditions that were imposed, and discuss the test results.

Identify the ASTM, ASME, or other standard specification that corresponds to the steel. Include in the description, the types, sizes, and dimensions of specimens that were tested. An ASTM or ASME specification and grade designation (e.g., ASTM A 516, Grade 60 or ASME SA-516, Grade 60) are usually sufficient to identify and describe a containment steel.

Carbon steels are typically used to create the pressure boundary of metal, reinforced concrete, and posttensioned concrete containments. Section III, Divisions 1 and 2 of the ASME Boiler and Pressure Vessel Code (Refs. 1.1 and 1.2) contain lists of materials permitted for use in containment construction. Although many other materials are routinely used inside the containment as conduits, pipes, and ducts, these materials are not considered to be containment steels.

Identify the material supplier and describe the manufacturing processes that were used to produce the steel.

Provide baseline or reference property data such as the minimum specified ultimate tensile and yield strength of the material, and the minimum elongation requirements.

Include a complete list of references that contain the data and information being reported. Whenever possible, a copy of each reference should also be provided. 
Table 1.1 (cont.) Containment steel data and information requirements.

\section{MATERIAL COMPOSITION}

Chemical Requirements

If available, a copy of the certified mill test report that corresponds to the heat that was used to produce the steel should be provided along with a copy of the chemical analysis of the finished product.

\section{PROPERTIES}

Mechanical Properties

Thermal, Physical, and Other Properties
Test results for individual specimens should be reported along with a complete description of each specimen. A discussion of the test methods and test conditions (specimen temperature, rate of loading, etc.) used to develop the data should also be provided. Although a plot or graph of the results may be sufficient, tabulated test results for each specimen are preferred. If available, the actual yield strength, modulus of elasticity, and ultimate tensile strength of each specimen should also be reported.

Test results for individual specimens should be reported along with a complete description of each specimen. A discussion of the test methods and test conditions (specimen temperature, rate of heating, thermal aging and environmental exposure conditions, etc.) used to develop the data should also be provided. Although a plot or graph of the results may be sufficient, tabulated test results are preferred. If available, ambient-temperature properties should also be reported. 


\subsection{CONTAINMENT VESSEL PRESSURE BOUNDARIES}

\subsection{CONCRETE AND METAL CONTAINMENT VESSELS}

Containment vessels for nuclear power plants are of two primary types - reinforced concrete and steel. The containment system includes: (1) the containment vessel; (2) all penetration assemblies or appurtenances attached to the containment vessel; and (3) all piping, pumps, and valves attached to the containment vessel, or to penetrations assemblies out to and including any valves required to isolate the system and provide a pressure boundary for the containment function (Refs. 2.1 and 2.2). Rules for containment vessel design and construction are provided in Section III of the ASME Boiler and Pressure Vessel Code. Section III was first published in 1921 and contained rules for locomotive boilers (Ref. 2.3). However, with changing technology and the development of nuclear power in the 1950 s and early 1960s, a new Section III was issued in 1963. The new rules contained requirements for three classes of components and were applicable to steel nuclear containments. Prior to 1963, most steel containments were designed and constructed based on rules provided in Section VIII for unfired pressure vessels. The rules in Section III for Class MC (metal) containments were significantly revised and published in the 1971 Edition, Summer Addenda of the Code. Rules for Class CC (concrete) containments were added to Section III in 1975. Concrete containments designed and constructed prior to 1975 were based on consensus documents published by the American Concrete Institute.

Concrete containment vessels are metal lined, reinforced concrete pressure-resisting structures that, in some cases, may also be post-tensioned. The concrete vessel includes the structural concrete pressure-resisting shell and shell components, shell metallic liners, and penetration liners that extend the containment liner through the surrounding shell concrete. The reinforced concrete shell, which generally consists of a cylindrical wall with a hemispherical or ellipsoidal dome and flat base slab (Fig. 2.1), provides the necessary structural support and resistance to pressureinduced forces. Leaktightness is provided by a steel liner fabricated from plates that may be as thin as $6.4 \mathrm{~mm}$ (0.25 in.). As non-structural components, concrete containment liners are not required to resist service loads or pressure-induced forces. Rules for construction of concrete containments are provided in Section III, Division 2, Subsection CC of the Code (Ref. 2.1).

Metal containment vessels fall into six general categories (1) BWR Mark I (Fig. 2.2), (2) BWR Mark II (Fig. 2.3), (3) BWR Mark III (Fig. 2.4), (4) BWR and PWR spherical (Fig. 2.5), (5) PWR cylindrical with hemispherical top and ellipsoidal base (Fig. 2.6), and (6) PWR cylindrical with hemispherical dome and flat base (i.e., ice condenser) (Fig. 2.7). With the exception of the spherical containments, free-standing metal containment vessels are generally enclosed in a reinforced concrete reactor or shield building. Rules for construction of metal containments are provided in Section III, Division 1, Subsection NE of the Code (Ref. 2.2). Section III also addresses almost every aspect of metal containment design including methods for calculating the required minimum thickness of pressure retaining components. Components used to construct metal containment vessels are generally much thicker than the liners of reinforced concrete containment vessels because they are required to resist applied loads and operating pressures as well as create a leaktight pressure boundary. The Code recognizes that service-related degradation to pressure retaining components is possible, but rules for material selection and in-service degradation are outside its scope. According to the Code, it is the Owner's responsible to select materials that are suitable for the service conditions and to increase the minimum required thickness of the base metal to offset material thinning due to corrosion, erosion, mechanical abrasion, or other environmental effects.

Since concrete containment vessels are covered under the Structural Aging Program (Ref. 2.4) and a data base containing long-term and environment-dependent properties for portland cement concretes, metallic reinforcements, prestressing tendons, and structural steels has 
been established (Ref. 2.5), these materials will not be considered in the balance of this report. Materials of primary interest to the present study are the steels used in the construction of metal containment vessels and the liners of the reinforced concrete containment vessels. Concrete containment liner steels were not considered under the Structural Aging Program.

\subsection{CONTAINMENT PRESSURE BOUNDARY STEELS}

All containments include pipes, electrical penetration assemblies, equipment hatches, manways, air locks, etc., as part of the pressure boundary. These components are generally either welded or bolted to the liners and shells and typically have compositions and properties that are significantly different from those of the liner and shell materials. Material specifications and property values for ferrous materials permitted for construction of concrete and metal containments are provided in Section II, Parts A and D of the Code (Refs. 2.6 and 2.7). Part A contains material specifications for ferrous metals that were developed by the American Society for Testing and Materials (ASTM) and adopted by ASME. These specifications represent a consensus among producers, specifiers, fabricators, and users of steel products. Material specifications adopted by ASME are identified by the prefix " $S$ " followed by the appropriate ASTM designation. For example, specifications ASME SA-516/SA-516M (Ref. 2.6) and ASTM A 516/A 516M-86 (Ref. 2.8) are identical. Part D contains maximum allowable stress values, design stress intensity values, and thermal properties for all ferrous and nonferrous materials cited in the Code. Tabulated information in Part D is organized according to the nominal composition of the materials. The ASME specification designations are used to distinguish one material from another, and materials with similar compositions and characteristics are grouped together.

The Code only permits the use of certain materials for construction of concrete and metal containment pressure boundary components. These materials must conform to ASME or ASTM material specifications. Tables 2.1 to 2.4 list the material specifications permitted by the 1992 edition of the Code (Refs. 2.1 and 2.2) for this purpose. The Code also specifies which grade, class, or type of steel is permitted for a particular application. For example, even though specifications ASME SA-738/SA-738M (Ref. 2.6) and ASTM A 738/A 738M (Ref. 2.9) are identical, steel plates that conform to Grade $\mathrm{A}, \mathrm{B}$, and $\mathrm{C}$ requirements are permitted for use in construction of concrete containment liners, but only plates that conform to Grade A and C requirements are permitted for use in construction of metal containment vessels. The lists of materials permitted for use in containment vessel construction often change from one edition of the Code to another. Actions taken by ASME and ASTM committees to delete, merge, edit, or modify existing materials specifications and to adopt new ones can initiate a revision.

\subsection{POTENTIAL DEGRADATION MECHANISMS}

\subsubsection{Corrosion}

Corrosion is a chemical or electrochemical reaction between a material, usually a metal, and its environment that produces a deterioration of the material and its properties (Ref. 2.10). General corrosion, localized corrosion, metallurgically influenced corrosion, mechanically assisted degradation, and environmentally induced cracking are five common types of corrosion that can manifest themselves in various forms such as the ones listed in Table 2.5 (Ref. 2.11).

During the operating life of a nuclear power plant, the structural and leaktight integrity of the containment could potentially be jeopardized due to corrosion of materials used to construct pressure boundary components. Effects of corrosion can be categorized as either changes in com-

ponent geometry or degradation of material properties. Uniform thinning and pitting are examples of corrosion-induced degradation that could, if left unchecked, result in significant loss of section 
or full-thickness penetration. Hydrogen embrittlement and stress-corrosion cracking are two forms of corrosion that alter the microstructure of certain steels and thereby influence their mechanical properties. The following sections contain discussions about each of the five types of corrosion listed in Table 2.5, and identify which forms of corrosion could potential degrade the properties of steels permitted for use in construction of containment pressure boundary components.

\section{General and Localized Corrosion}

General corrosion of steel is degradation that produces uniform thinning and proceeds without appreciable localized attack. This type of corrosion is characterized by slow, relatively uniform loss of metal thickness over a wide area. Localized corrosion is similar to general corrosion except the rate of attack is usually much faster and the size of the affected area is significantly smaller. Degradation caused by either of these two corrosion processes begins at an exposed metal surface and progressively alters the geometry of the affected component without changing the chemical composition of the material or its microstructure. Damage caused by localized corrosion is often difficult to detect and quantify because visible surface defects tend to be small and often do not provide a good indication of the extent of damage that has occurred under the surface (Ref. 2.11). Specific forms of general and localized corrosion are identified in Table 2.5.

The most significant consequence of general and localized corrosion of steels used to construct containment pressure boundary components is loss of section that could result in reduced load-carrying capacity and possible containment leakage. Although these consequences are significant containment issues, information about steels subjected to general and localized corrosion will not be collected at the Structural Materials Information Center because these corrosion processes are thought to have no measurable effect on properties of steel materials used in the construction of pressure boundaries of containment vessels.

\section{Metallurgically Influenced Corrosion}

Intergranular and dealloying corrosion are two forms of metallurgically influenced corrosion that are affected by alloy chemistry and heat treatment (Ref. 2.11). Intergranular corrosion takes place when the corrosion rate of the grain-boundary areas of an alloy exceed that of the grain interiors. Differences in composition between the grain boundaries and the interior cause differences in the corrosion rates. As the grain boundaries dissolve, the unaffected grains are undermined and fall out. Consequently, metals that experience intergranular corrosion exhibit timedependent weight loss that can accelerate with time. Dealloying is a corrosion process in which one constituent of an alloy is preferentially removed leaving behind an altered residual structure. The metal in the affected area becomes porous and loses much of its strength, hardness, and ductility. Because metallurgically influenced corrosion of steel alters its chemical composition and changes its microstructure, it can affect the properties of the metal. For these reasons, a search for data and information pertaining to steels listed in Tables 2.1 to 2.4 subjected to metallurgically influenced corrosion will be conducted at the Structural Materials Information Center.

\section{Mechanically Assisted Degradation}

Any type of degradation that involves both a corrosion mechanism and mechanical wear or fatigue is considered to be mechanically assisted degradation (Ref. 2.11). Erosion, fretting, cavitation, and fatigue are mechanical actions that can contribute to mechanically assisted degradation. Steels used to construct containment pressure boundary components are not routinely subjected to wear caused by erosion, fretting, or cavitation, and fatigue of pressure retaining components is not expected to be a generic concern (Ref. 2.12). Therefore, experimental data showing the effects of mechanically assisted degradation including corrosion fatigue on steel properties will not be collected at the Structural Materials Information Center. 


\section{Environmentally Induced Cracking}

Environmentally induced cracking is a type of degradation that occurs when cracks are produced in metals as a result of exposure to an environment. Stress-corrosion cracking (SSC), hydrogen damage, liquid metal embrittlement, and solid metal induced embrittlement are four forms of degradation commonly associated with environmentally induced cracking (Ref. 2.11). In general, as the yield strength and stress applied to a metal increase, its resistance to environmentally induced cracking decreases. For steels in light-water nuclear reactor plants, only two of these phenomena, stress-corrosion cracking and hydrogen damage, are possible because liquid metals are not present.

\section{Stress-Corrosion Cracking}

Stress-corrosion cracking is a material degradation process that requires the simultaneous action of a corrodent and sustained tensile stress to initiate and propagate cracks in metals and alloys. It excludes corrosion-reduced sections that fail by fast fracture as well as intercrystalline or transcrystalline corrosion that can disintegrate an alloy without the presence of either applied or residual stress (Ref. 2.10). Relatively low tensile stresses, often below the yield strength of the material, can cause stress-corrosion cracking. These stresses may be produced by applied loads, residual stresses, or wedging action caused by the growth of corrosion products. Compressive stresses are beneficial in reducing or eliminating stress-corrosion cracking.

Carbon, low-alloy, and stainless steels exposed to various aqueous environments are susceptible to stress-corrosion cracking. A partial list of these environments is presented in Table 2.6 (Ref. 2.13). Alloys that are resistant to general corrosion in a particular environment are often susceptible to stress-corrosion cracking. Austenitic stainless steel is a good example. When unstressed samples of this material are exposed to a chloride environment, they exhibit excellent corrosion resistance. However, when they are stressed, they exhibit premature fracture that can be attributed to stress-corrosion cracking. Other factors including temperature of the environment, degree of aeration, and differences in $\mathrm{pH}$ can also influence whether a particular alloy is or is not susceptible to stress-corrosion cracking (Ref. 2.13).

Material failure caused by stress-corrosion cracking is a time-dependent phenomenon. Crack initiation requires an incubation period followed by a crack propagation phase. Cracking continues until the applied stress exceeds the strength of the remaining cross section. Standard test methods such as ASTM G 36, G 38, G 39, G 44, and G 49 (Refs. 2.14 to 2.18) are often used to evaluate stress-corrosion cracking. In these tests, smooth metal specimens are subjected to relatively severe environmental conditions such as boiling magnesium chloride while a constant stress is applied to the specimens. Results from these tests are used primarily for material selection purposes. The assumption is that materials that do not crack under these test conditions will be suitable for use at the same stress level in a similar but less severe environment. Occasionally, crack growth rates are established by periodically measuring the depth of crack propagation.

If available, experimental data and results obtained from stress-corrosion testing will be collected at the Structural Materials Information Center and used to develop performance curves that reflect time-dependent stress-corrosion behavior. Search efforts will focus on steels listed in Tables 2.1 to 2.4 that have been exposed to ground water containing chlorides or sulfates, borated water, sodium pentaborate, or other aqueous solutions that could be considered potentially corrosive to steels in nuclear power plants.

\section{Hydrogen Damage}

Hydrogen influences the behavior and properties of nearly all ferrous alloys, particularly steels in which the yield strength is close to the ultimate strength. For plain carbon steels, combi- 
nations of high temperature and low hydrogen pressure or low temperature and high hydrogen pressure, can contribute to hydrogen attack (Ref. 2.19). Even austenitic stainless steels that were once thought to be immune from hydrogen embrittlement are susceptible (Ref. 2.13). Factors known to contribute to hydrogen-induced damage include temperature, hydrogen pressure, alloy, heat treatment, surface condition, and strains from cold work (Ref. 2.19).

Cracking or severe loss of ductility caused by the presence of hydrogen in the metal lattice is called hydrogen embrittlement. There are three categories of damage associated with hydrogen embrittlement - hydrogen environmental embrittlement, hydrogen stress cracking, and loss of tensile ductility. Hydrogen environmental embrittlement is mechanical property degradation that occurs when steel is deformed in a hydrogen environment. Hydrogen stress cracking is brittle fracture that occurs when steel is stressed in a hydrogen environment. Loss of tensile ductility is damage that occurs when low-strength steels are exposed to hydrogen (Ref. 2.13),

Under normal operating conditions, the atmosphere inside a containment is controlled such that the pressure, temperature, and chemical makeup are nearly constant (Ref. 2.12). However, during certain unlikely events such as a postulated loss of coolant accident (LOCA), hydrogen gas can be generated as the result of the chemical reaction of zircaloy with water or as the result of radiolytic decomposition of water. Two other possible sources of hydrogen in a nuclear power plant are from battery charging operations and impressed-current cathodic protection systems, neither of which produce significant amounts of hydrogen except in localized areas. During normal plant operations, hydrogen embrittlement of pressure retaining steels is not expected to be a serious problem. Therefore, experimental data showing the effects of hydrogen on steel properties will not be collected at the Structural Materials Information Center.

\subsubsection{Fatigue}

In most cases, the factors that cause changes in liner stress and strain levels with time (fatigue) occur only a small number of times and produce only minor changes in magnitude. The design of liners for reinforced concrete containments therefore is generally not controlled by fatigue considerations (Ref. 2.2). However, fatigue may be considered a design issue in certain parts or areas of metal containments where thermal stress ratcheting occurs. Combinations of steady state and cyclic loadings that produce a ratcheting action can cause a continuing increase in component deformation eventually leading to component failure. Guidance for performing fatigue evaluations under these conditions is provided in Section III, Division 1 of the Code (Ref. 2.2).

The suitability of a component for cyclic operations can be determined in two ways - using information presented in the Code, or conducting fatigue tests. In a fatigue analysis, allowable stress limits and corresponding numbers of permitted stress cycles are evaluated using fatigue design curves presented in Section III, Division 1, Appendix I (Ref. 2.20). These curves reflect actual material performance because they were developed using results from uniaxial strain cycling tests. Values obtained from these curves include an appropriate safety factor. The fatigue resistance of a material or component can also be evaluated by cyclic load testing. The test sample should be fabricated using a material having similar properties and composition to that of the prototype. Results of cyclic load testing, however, can not be used as justification for exceeding the allowable values of primary or primary plus secondary stresses provided by the fatigue design curves contained in Appendix I.

Although design rules for fatigue of steels used to construct containment pressure boundary components are included in the Code, fatigue is not expected to be a generic concern for either liners of reinforced concrete containments or the shells of metal containments (Ref. 2.12). Consequently, the effects of fatigue on containment steel properties will not be collected at the Structural Materials Information Center. 


\subsubsection{Neutron Irradiation}

Properties of steel can be adversely affected by exposure to neutron irradiation. Damage occurs when neutrons displace metal atoms from their normal lattice positions to form interstitials and vacancies. The effects of neutron irradiation, which include volume increase, hardening, and embrittlement, are primarily associated with high-energy neutrons (greater than $0.1 \mathrm{MeV}$ ). However, thermal neutrons such as the ones produced in light-water reactors (energies much less than $1 \mathrm{MeV}$ ) can also cause irradiation damage to steel components such as the reactor pressure vessel (Ref. 2.13).

Compared to the reactor pressure vessel, containment pressure boundary steel components are much less susceptible to irradiation damage because biological shielding effectively limits the exposure of the materials to levels that are considered safe for occupational workers, and end-oflife fluence of containment components is anticipated to be quite small (Ref. 2.12). Even in the unlikely event of a severe accident, irradiation damage to these steels is not expected to be significant. For this reason, experimental data showing the effects of neutron irradiation on containment steel properties will not be collected at the Structural Materials Information Center.

\subsubsection{Extreme Temperature Exposure}

\section{High Temperature}

Carbon, low-alloy, and stainless steels are used routinely for elevated-temperature structural applications even though strength and elastic properties of these materials change as exposure temperature increases. Suggested maximum operating temperature limits range from about 400 to $540^{\circ} \mathrm{C}\left(750\right.$ to $\left.1,000^{\circ} \mathrm{F}\right)$ for carbon steels to about $815^{\circ} \mathrm{C}\left(1,500^{\circ} \mathrm{F}\right)$ for certain stainless steels (Ref. 2.13). Temperature-dependent stress limits and high-temperature design rules for steels permitted for use in construction of containment pressure boundary components are provided in the Code (Refs. 2.1, 2.2, and 2.7).

According to Code rules, the design temperature for metal containments is the maximum containment temperature that can occur while the maximum containment pressure is being applied. Normal upper operating temperatures inside metal containments ranges from 57 to $66^{\circ} \mathrm{C}(135$ to $\left.150^{\circ} \mathrm{F}\right)$ for BWR Mark I containments and up to $49^{\circ} \mathrm{C}\left(120^{\circ} \mathrm{F}\right)$ ) for PWR containments (Ref. 2.12). Concrete containment liner temperature limits are established by the concrete temperature limits specified in the Code. The Code requires that concrete temperatures remain below $66^{\circ} \mathrm{C}\left(150^{\circ} \mathrm{F}\right)$ during normal plant operations $\left[93^{\circ} \mathrm{C}\left(200^{\circ} \mathrm{F}\right)\right.$ at local areas such as around penetrations] and never exceed $343^{\circ} \mathrm{C}\left(650^{\circ} \mathrm{F}\right)$ during a pipe failure event. Even though temperaturedependent maximum allowable stress and design stress intensity values are provided in the Code, efforts will be made at the Structural Materials Information Center to collect data and information on the effects of elevated-temperatures on the properties of containment steels listed in Tables 2.1 to 2.4 .

\section{Low Temperature}

Steel structures exposed to low temperatures are susceptible to brittle failure that can initiate at defects and cracks caused by fatigue, arc welding strikes, gouges, or other types of physical damage. Because structures cannot be fabricated perfectly, material defects and minor construction imperfections will always be present. However, chances for brittle failure can be minimized or eliminated by proper material selection and periodic in-service inspection. To ensure safe and reliable operation, critical structural components are generally constructed using steels that exhibit adequate low-temperature fracture toughness. 
Steels used to construct containment pressure boundary components must comply with the fracture toughness requirements provided in the Code (Ref. 2.1 and 2.2). These rules, which factor in the nil-ductility transition temperature of the steel (Ref. 2.21) and the lowest temperature that the steel could experience while the plant is in operation, are used to establish the permissible lowest service metal temperature (LSMT). The fracture toughness requirements in the Code suggest that as long as suitable steels are selected and the temperature of pressure retaining steel components remains above the LSMT, the fracture toughness will be adequate to ensure safe and reliable operation. The effects of low-temperatures on the properties of containment steels will not be collected at the Structural Materials Information Center because low-temperature exposure and fracture toughness are addressed during containment design, and because operation below the LSMT is not expected.

\subsection{REFERENCES}

2.1 "Rules for Construction of Nuclear Power Plant Components," ASME Boiler and Pressure Vessel Code, Section III, Division 2, Code for Concrete Reactor Vessels and Containments, Subsection CC, Concrete Containments (Prestressed or Reinforced), American Society of Mechanical Engineers, New York, New York, July 1, 1992.

2.2 "Rules for Construction of Nuclear Power Plant Components," ASME Boiler and Pressure Vessel Code, Section III, Division 1 - Subsection NE, Class MC Components, American Society of Mechanical Engineers, New York, New York, July 1, 1992.

2.3 Sammataro, R. F., "Updated ASME Code Rules for Inservice Inspection of Steel and Concrete Containments", Fifth Workshop on Containment Integrity, sponsored by the U.S. Nuclear Regulatory Commission, held at the Washington Marriott Hotel, Washington, DC, May 12-14, 1992.

2.4 Naus, D. J. and Oland, C. B., Structural Aging Program Technical Progress Report for Period January 1, 1993, to June 30, 1994, ORNL/LTR-94/21, Martin Marietta Energy System, Inc., Oak Ridge National Laboratory, Oak Ridge, Tennessee, November 1994.

2.5 Oland, C. B. and Naus, D. J., Summary of Materials Contained in the Structural Materials Information Center, ORNL/LTR-94/22, Martin Marietta Energy System, Inc., Oak Ridge National Laboratory, Oak Ridge, Tennessee, November 1994.

2.6 "Materials," ASME Boiler and Pressure Vessel Code, Section II, Part A - Ferrous Materials Specifications, American Society of Mechanical Engineers, New York, New York, July 1, 1992.

2.7 "Materials," ASME Boiler and Pressure Vessel Code, Section II, Part D - Properties, American Society of Mechanical Engineers, New York, New York, July 1, 1992.

2.8 "Standard Specification for Pressure Vessel Plates, Carbon Steel, for Moderate- and Lower-Temperature Service," ASTM Designation: A 516/A 516M-86, 1990 Annual Book of ASTM Standards, Vol. 01.04, American Society for Testing and Materials, Philadelphia, Pennsylvania, 1990, pp. 320-322.

2.9 "Standard Specification for Pressure Vessel Plates, Heat-Treated, Carbon-ManganeseSilicon Steel, for Moderate and Lower Temperature Service," ASTM Designation: A 738/A 738M-87a, 1990 Annual Book of ASTM Standards, Vol. 01.04, American Society for Testing and Materials, Philadelphia, Pennsylvania, 1990, pp. 534-536. 
2.10 "Standard Terminology Related to Corrosion and Corrosion Testing," ASTM Designation: G 15-90a, 1991 Annual Book of ASTM Standards, Vol. 03.02, American Society for Testing and Materials, Philadelphia, Pennsylvania, 1991, pp. 80-83.

2.11 "Volume 13 - Corrosion," ASM Handbook, formerly ninth edition, Metals Handbook, ASM INTERNATIONAL, Materials Park, Ohio, September 1987.

2.12 Shah, V. N., Smith, S. K., and Sinha, U. P., Insights for Aging Management of Light Water Reactor Components - Metal Containments, NUREG/CR-5314, EGG-2562, Vol. 5, Idaho National Engineering Laboratory, EG\&G Idaho, Inc., Idaho Falls, Idaho, March 1994.

2.13 "Volume 1 - Properties and Selection: Irons, Steels, and High-Performance Alloys," Metals Handbook, Tenth Edition, ASM INTERNATIONAL, Materials Park, Ohio, March 1990.

2.14 "Standard Practice for Evaluating Stress-Corrosion-Cracking Resistance of Metals and Alloys in a Boiling Magnesium Chloride Solution," ASTM Designation: G 36-87, 1991 Annual Book of ASTM Standards, Vol. 03.02, American Society for Testing and Materials, Philadelphia, Pennsylvania, 1991, pp. 128-133.

2.15 "Standard Practice for Making and Using C-Ring Stress-Corrosion Test Specimens," ASTM Designation: G 38-73, 1991 Annual Book of ASTM Standards, Vol. 03.02, American Society for Testing and Materials, Philadelphia, Pennsylvania, 1991, pp. 137142.

2.16 "Standard Practice for Preparation and Use of Bend-Beam Stress-Corrosion Test Specimens," ASTM Designation: G 39-90, 1991 Annual Book of ASTM Standards, Vol. 03.02, American Society for Testing and Materials, Philadelphia, Pennsylvania, 1991, pp. 143-149.

2.17 "Standard Practice for Evaluating Stress Corrosion Cracking Resistance of Metals and Alloys by Alternate Immersion in a 3.5\% Sodium Chloride Solution," ASTM Designation: G 44-88, 1991 Annual Book of ASTM Standards, Vol. 03.02, American Society for Testing and Materials, Philadelphia, Pennsylvania, 1991, pp. 162-165.

2.18 "Standard Practice for Preparation and Use of Direct-Tension Stress-Corrosion Test Specimens," ASTM Designation: G 49-85, 1991 Annual Book of ASTM Standards, Vol. 03.02, American Society for Testing and Materials, Philadelphia, Pennsylvania, 1991, pp. 181-185.

2.19 Cantwell, J. E., "High-Temperature Hydrogen Attack," Materials Performance, Vol. 33, No. 7, National Association of Corrosion Engineers, Houston, Texas, July 1994, pp. 5861.

2.20 "Division 1 - Appendices," ASME Boiler and Pressure Vessel Code, Section III, American Society of Mechanical Engineers, New York, New York, July 1, 1992.

2.21 "Method for Conducting Drop-Weight Test to Determine Nil-Ductility Transition Temperature of Ferritic Steels," ASTM Designation: E 208-91, 1991 Annual Book of ASTM Standards, Vol. 03.01, American Society for Testing and Materials, Philadelphia, Pennsylvania, 1991, pp. 358-369. 


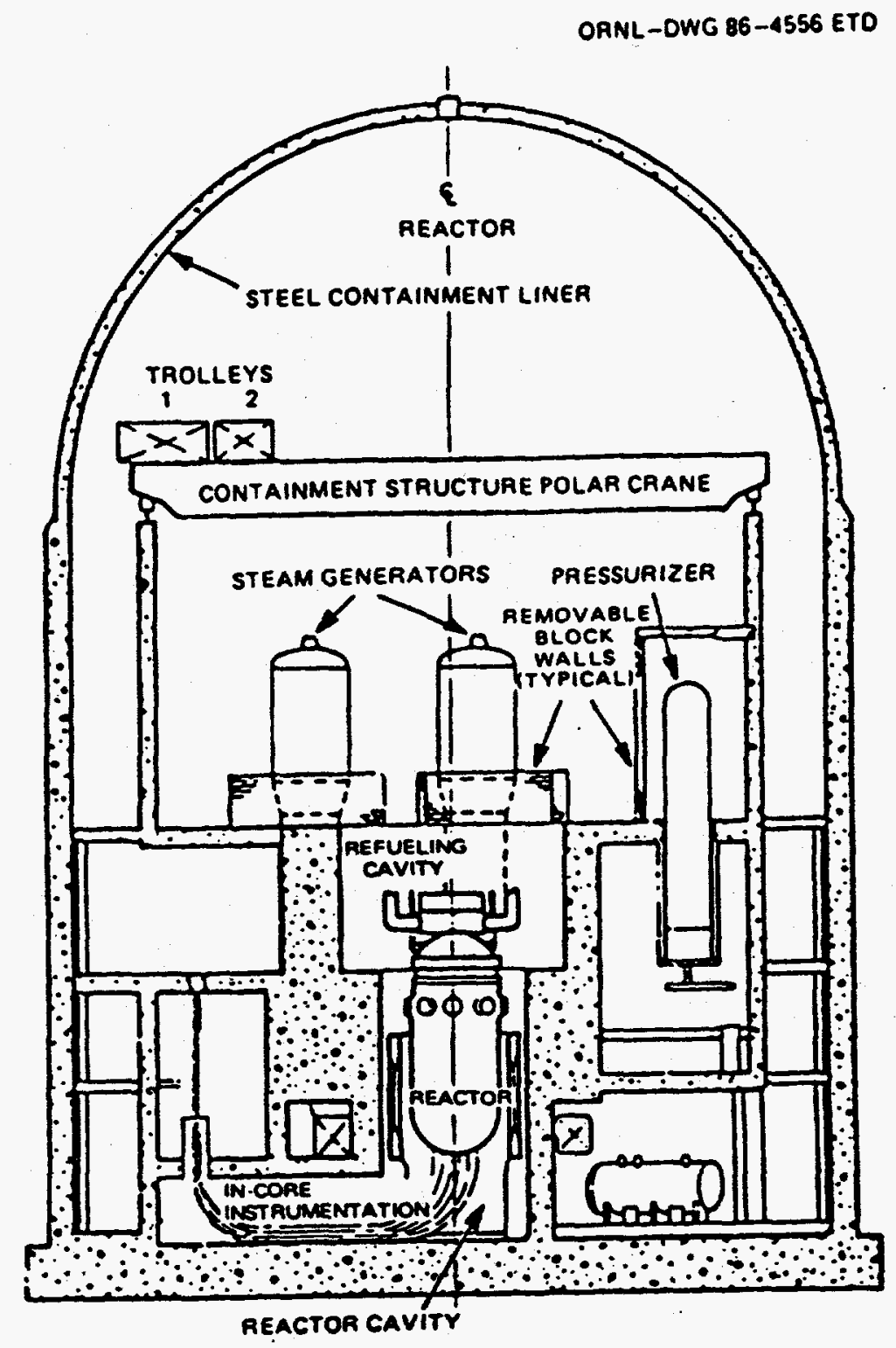

Fig. 2.1 PWR subatmospheric concrete containment configuration.

Source: Naus, D. J., Concrete Component Aging and Its Significance Relative to Life Extension of Nuclear Power Plants, NUREG/CR-4652 (ORNL/TM-10059), Oak Ridge National Laboratory, Oak Ridge, Tennessee, September 1986. 


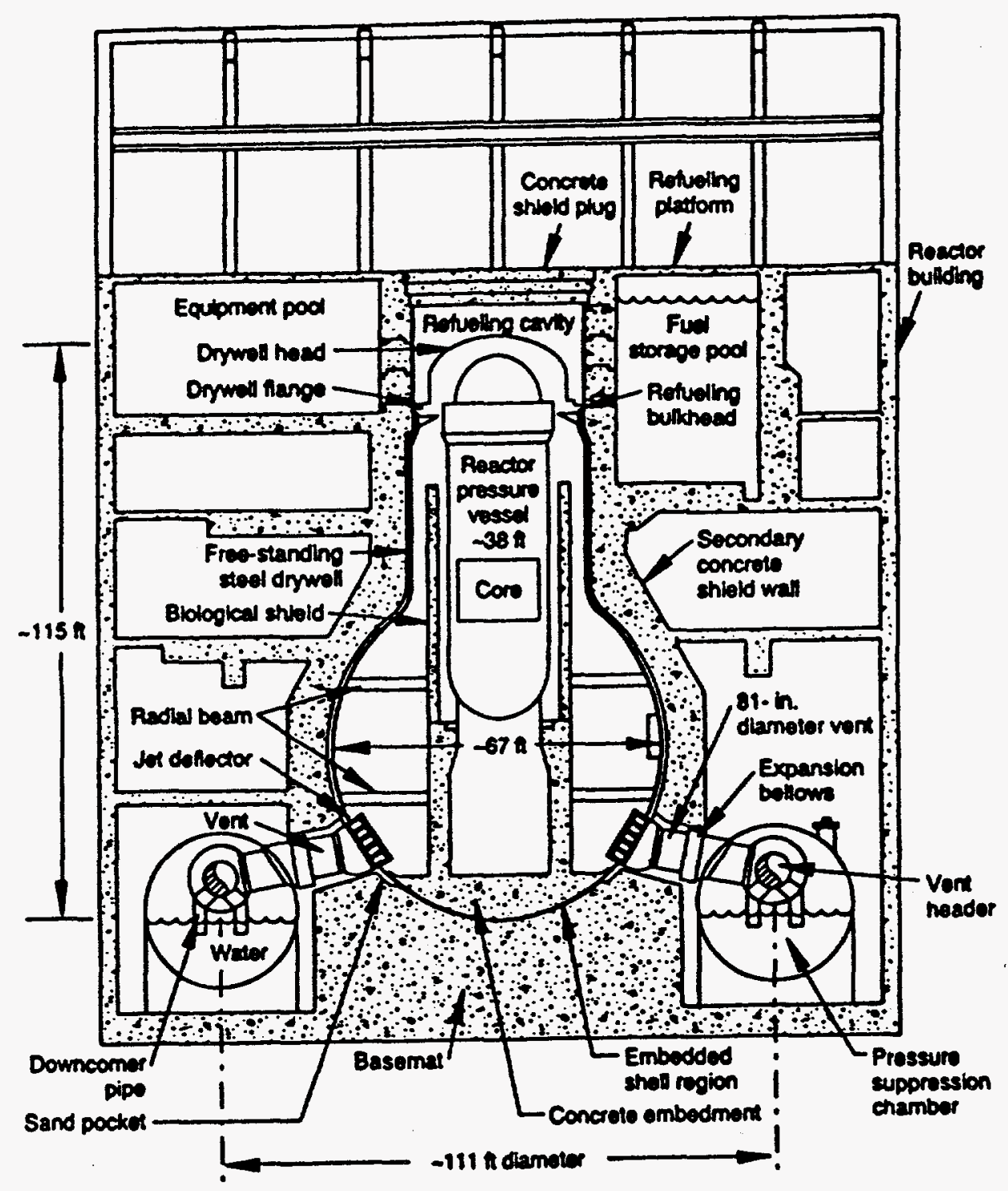

Fig. 2.2 BWR Mark I metal containment configuration.

Source: Shah, V. N., Smith, S. K., and Sinha, U. P., Insights for Aging Management of Light Water Reactor Components - Metal Containments, NUREG/CR-5314, EGG-2562, Vol. 5, Idaho National Engineering Laboratory, EG\&G Idaho, Inc., Idaho Falls, Idaho, March 1994. 


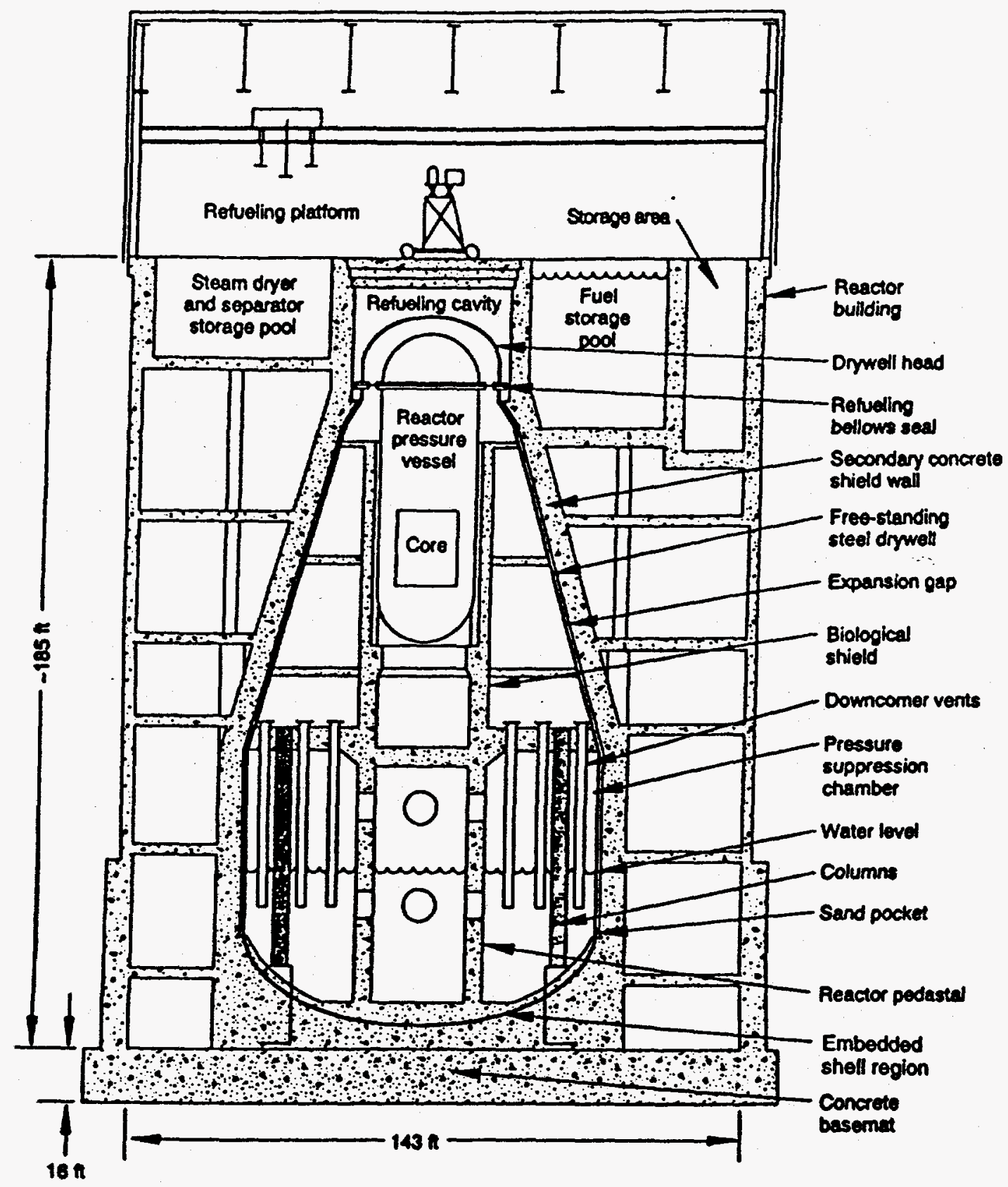

Fig. 2.3 BWR Mark II metal containment configuration.

Source: Shah, V. N., Smith, S. K., and Sinha, U. P., Insights for Aging Management of Light Water Reactor Components - Metal Containments, NUREG/CR-5314, EGG-2562, Vol. 5, Idaho National Engineering Laboratory, EG\&G Idaho, Inc., Idaho Falls, Idaho, March 1994. 


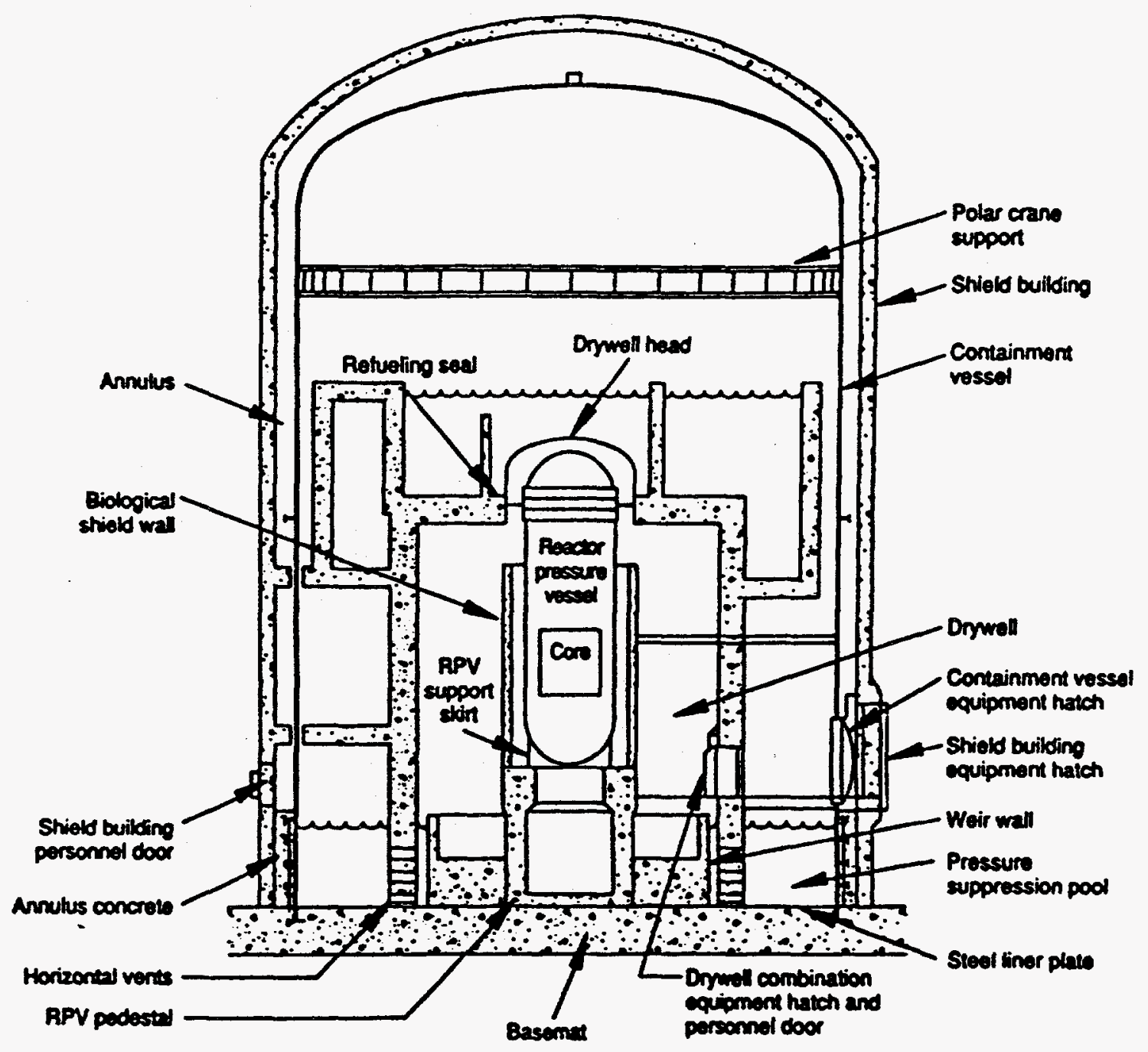

Fig. 2.4 BWR Mark III metal containment configuration.

Source: Shah, V. N., Smith, S. K., and Sinha, U. P., Insights for Aging Management of Light Water Reactor Components - Metal Containments, NUREG/CR-5314, EGG-2562, Vol. 5, Idaho National Engineering Laboratory, EG\&G Idaho, Inc., Idaho Falls, Idaho, March 1994. 


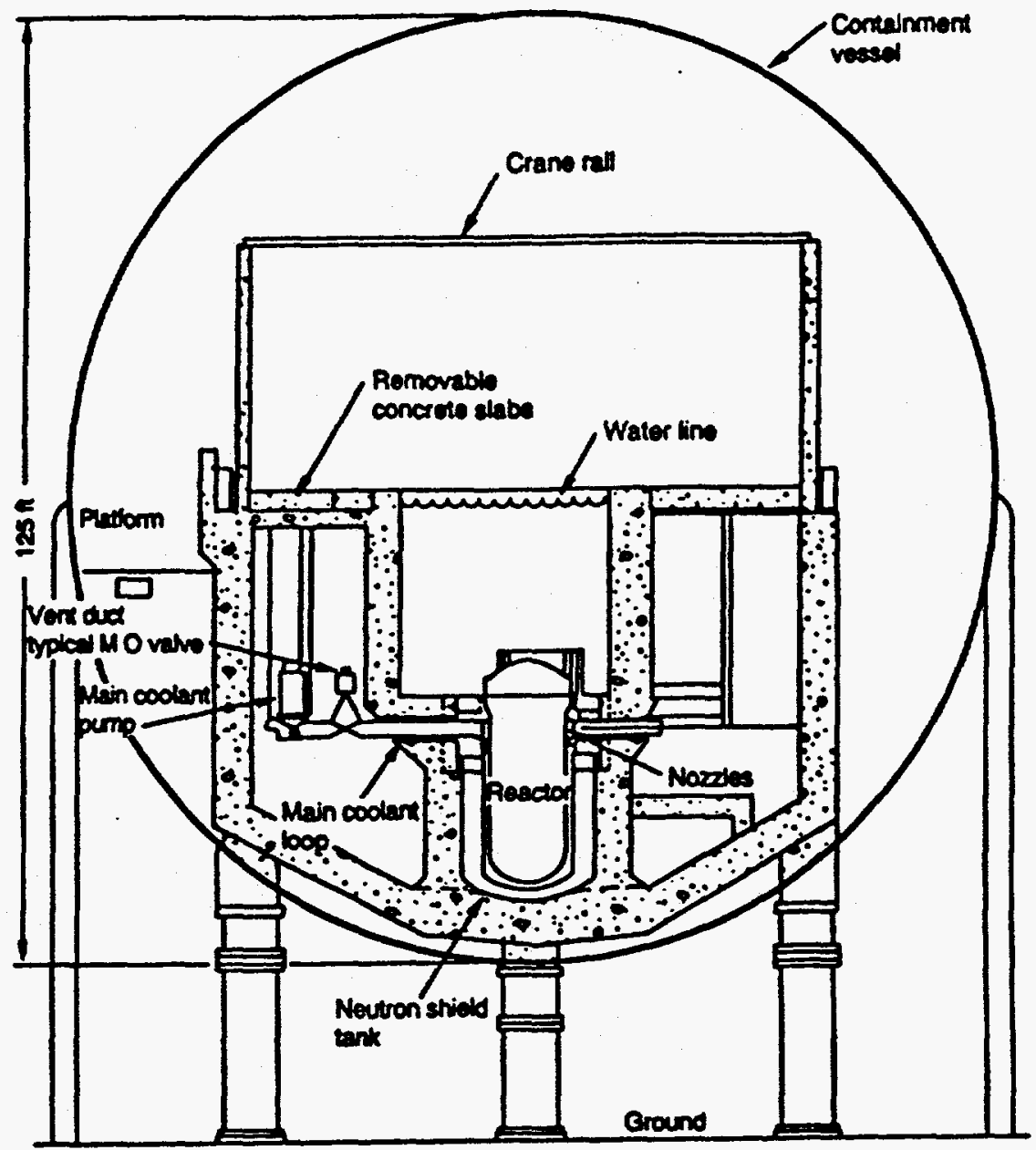

Fig. 2.5 PWR spherical metal containment configuration.

Source: Shah, V. N., Smith, S. K., and Sinha, U. P., Insights for Aging Management of Light Water Reactor Components - Metal Containments, NUREG/CR-5314, EGG-2562, Vol. 5, Idaho National Engineering Laboratory, EG\&G Idaho, Inc., Idaho Falls, Idaho, March 1994. 


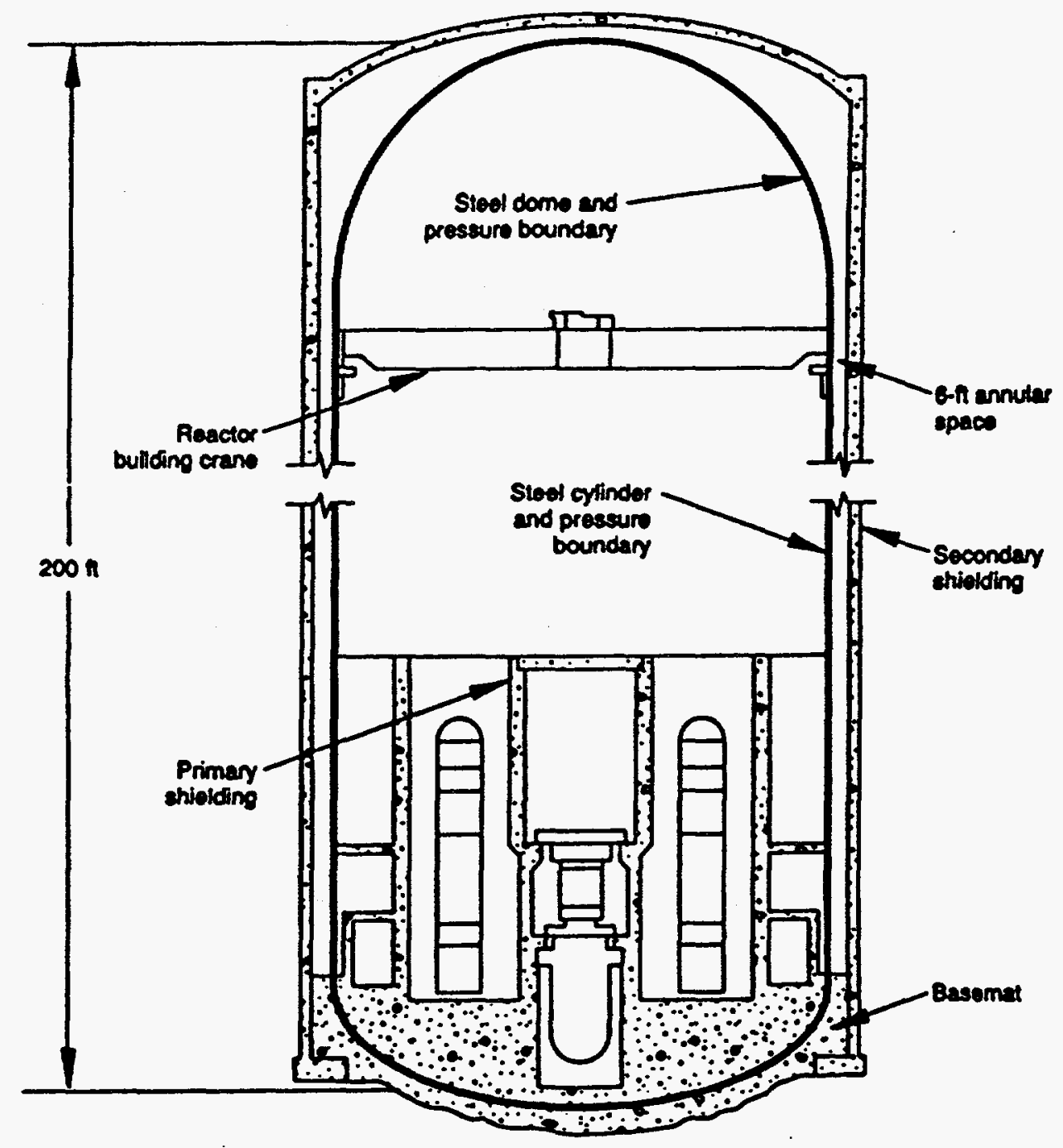

Fig. 2.6 PWR cylindrical metal containment configuration.

Source: Shah, V. N., Smith, S. K., and Sinha, U. P., Insights for Aging Management of Light Water Reactor Components - Metal Containments, NUREG/CR-5314, EGG-2562, Vol. 5, Idaho National Engineering Laboratory, EG\&G Idaho, Inc., Idaho Falls, Idaho, March 1994. 


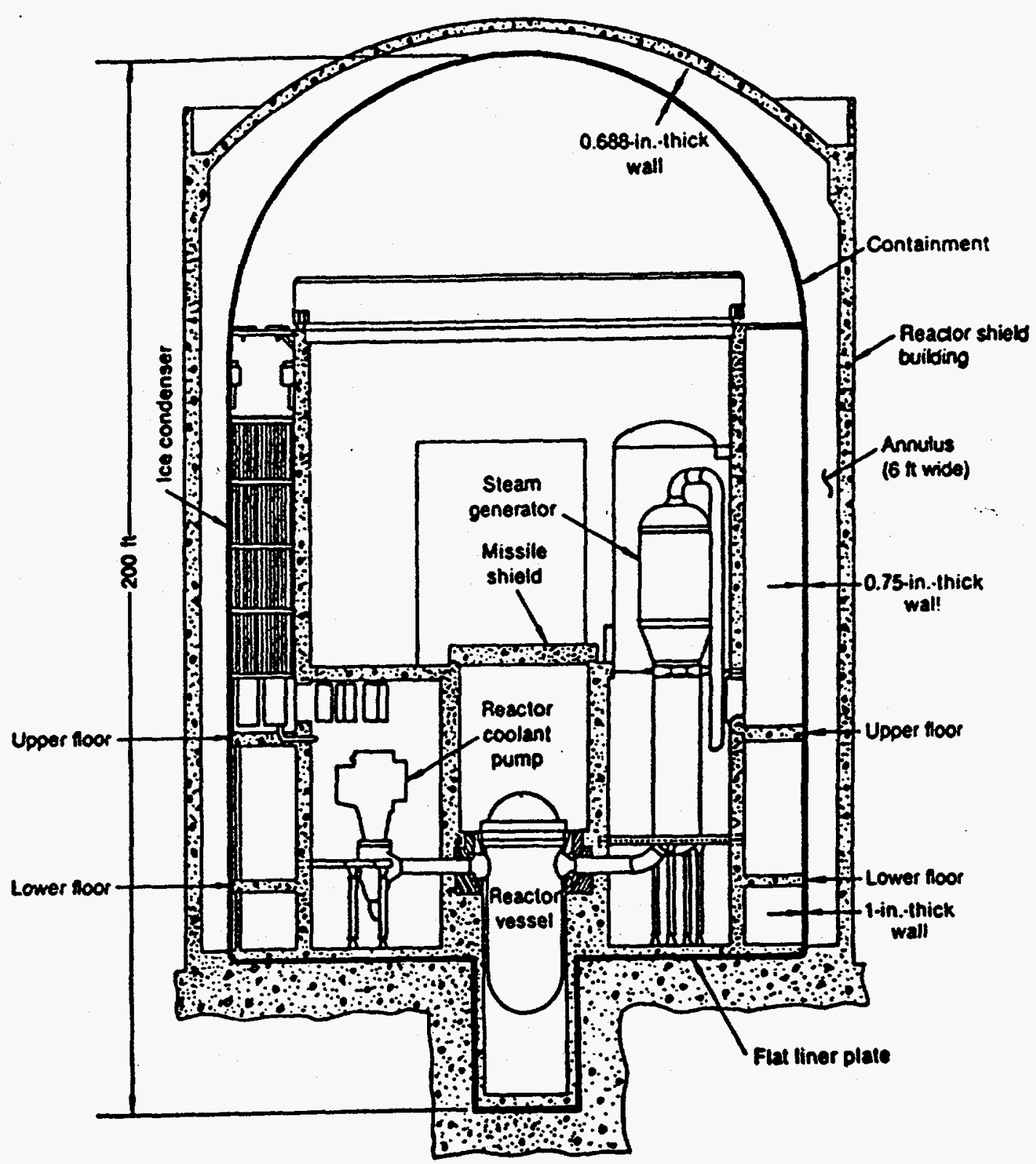

Fig. 2.7 PWR cylindrical ice-condenser metal containment configuration.

Source: Shah, V. N., Smith, S. K., and Sinha, U. P., Insights for Aging Management of Light Water Reactor Components - Metal Containments, NUREG/CR-5314, EGG-2562, Vol. 5, Idaho National Engineering Laboratory, EG\&G Idaho, Inc., Idaho Falls, Idaho, March 1994. 
Table 2.1 Material specifications permitted for construction of metal containments.

ASME

Specification Designation
ASTM

Specification Designation

\section{Carbon Steels}

SA-36*

SA-105*

SA-106

SA-178*

SA-181*

SA-210

SA-216

SA-234*

SA-266*

SA-299*

SA-333*

SA-334*

SA-350*

SA-352

SA-420

SA-442*

SA-487*

SA-508

SA-516*

SA-537*

SA-541*

SA-671

SA-691

SA-695

SA-696*

SA-737*

SA-738*
A 36

A 105

A 106

A 178

A 181

A 210

A 216

A 234

A 266

A 299

A 333

A 334

A 350

A 352

A 420

A 442

A 487

A 508

A 516

A 537

A 541

A 671

A 691

A 695

A 696

A 737

A 738

Precipitation Hardening Steels

SA-564

SA-693*

SA-705
A 564

A 693

A 705

High-Alloy Type 304 Stainless Steels

SA-182

SA-213

SA-240

SA-249

SA-312*
A 182

A 213

A 240

A 249

A 312 
Table 2.1 (cont.) Material specifications permitted for construction of metal containments.

ASME

Specification Designation
ASTM Specification Designation

High-Alloy Type 304 Stainless Steels (cont.)

SA-336
SA-351
SA-358
SA-376
SA-403
SA-430*
SA-452*
SA-479
SA-813*
SA-814*

A 336

A 351

A 358

A 376

A 403

A 430

A 452

A 479

A 813

A 814

\section{High-Alloy Type 316 Stainless Steels}

SA-182
SA-213
SA-240
SA-249
SA-312*
SA-336
SA-351
SA-358
SA-376
SA-403
SA-430*
SA-452*
SA-479
SA-813*
SA-814*

A 182

A 213

A 240

A 249

A 312

A 336

A 351

A 358

A 376

A 403

A 430

A 452

A 479

A 813

A 814

High-Alloy Type 309 and 310 Stainless Steels

SA-182
SA-213
SA-240
SA-249
SA-312*
SA-336
SA-351
SA-376
SA-403
SA-430*

A 182

A 213

A 240

A 249

A 312

A 336

A 351

A 376

A 403

A 430 
Table 2.1 (cont.) Material specifications permitted for construction of metal containments.

ASME

Specification Designation
ASTM

Specification Designation

High-Alloy Type 309 and 310 Stainless Steels (cont.)

SA-479

SA-813*

SA-814*
A 479

A 813

A 814

High-Alloy Type 347 and 348 Stainless Steels
SA-182
SA-213
SA-240
A 182
SA-249
A 213
SA-312*
A 240
SA-336
SA-351
SA-376
SA-403
A 249
A 312
A 336
A 351
A 376
SA-430*
SA-452*
A 403
SA-479
A 430
SA-813*
A 452
A 479
SA-814*
A 813
A 814

High-Alloy Type XM-19 Stainless Steels

$\begin{array}{lc}\text { SA-182 } & \text { A } 182 \\ \text { SA-240 } & \text { A } 240 \\ \text { SA-249 } & \text { A } 249 \\ \text { SA-312* } & \text { A } 312 \\ \text { SA-358 } & \text { A } 358 \\ \text { SA-403 } & \text { A } 403 \\ \text { SA-412 } & \text { A } 412 \\ \text { SA-479 } & \text { A } 479 \\ \text { SA-813* } & \text { A } 813 \\ \text { SA-814* } & \text { A } 814\end{array}$

* Identical with corresponding ASTM specification. 
Table 2.2 Material specifications permitted for bolting materials.

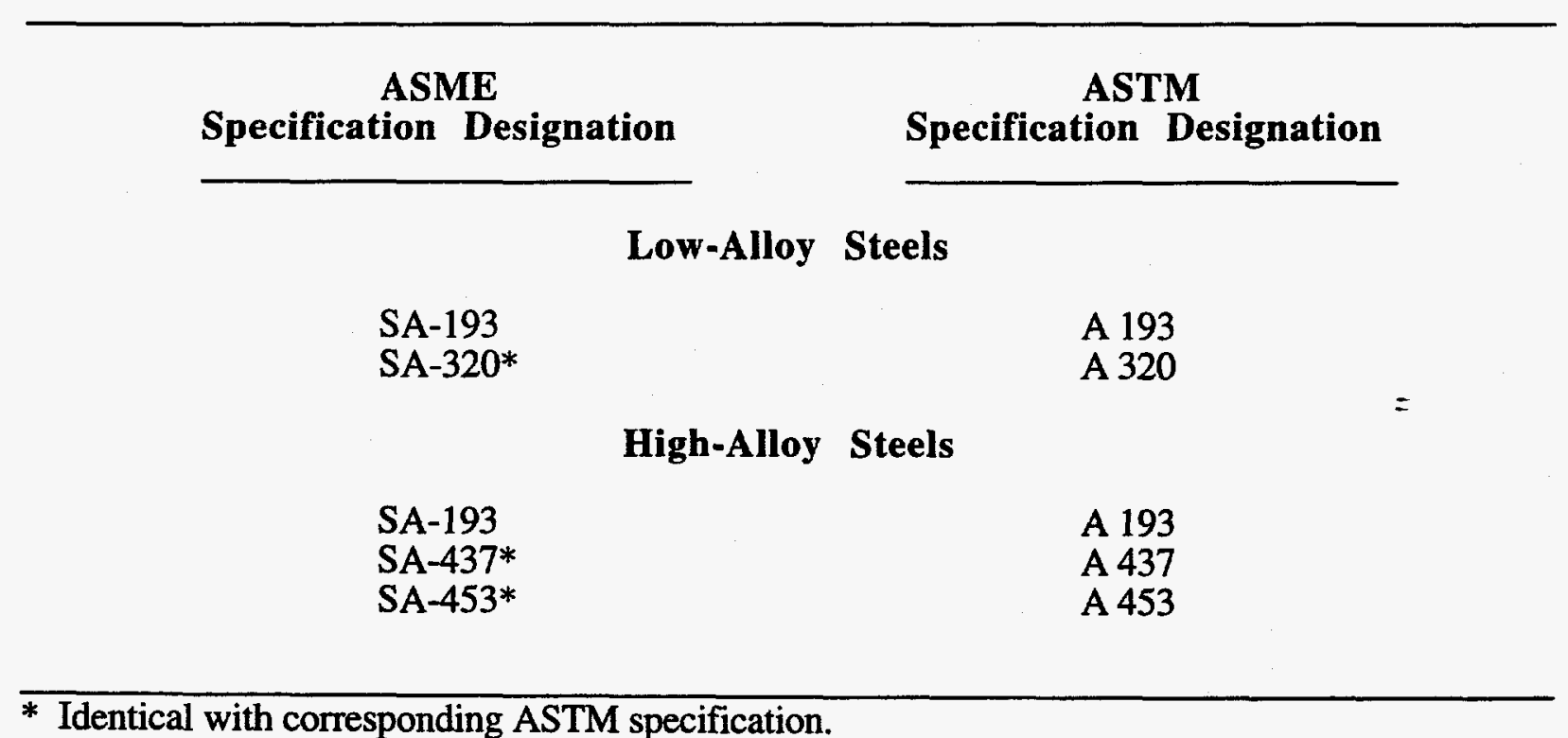

* Identical with corresponding ASTM specification. 
Table 2.3 Material specifications permitted for construction of concrete containment liners.

ASME Specification Designation
ASTM Specification Designation

\section{Carbon Steels}

SA-36*

SA-105*

SA-106

SA-178*

SA-181*

SA-210

SA-216

SA-234*

SA-266*

SA-285*

SA-299*

SA-333*

SA-334*

SA-350*

SA -420

SA-442*

SA-508

SA-516*

SA-537*

SA-541*

SA-738*

SA-213

SA-240

SA-312*

SA-351

SA-358

SA-376

SA-403

SA-430*

\section{High-Alloy Steels}

A 36

A 105

A 106

A 178

A 181

A 210

A 216

A 234

A 266

A 285

A 299

A 333

A 334

A 350

A 420

A 442

A 508

A 516

A 537

A 541

A 738 
Table 2.4 Material specifications permitted for reinforcing bar splice sleeves attached to concrete containment liners.

\begin{tabular}{|c|c|}
\hline $\begin{array}{c}\text { ASME } \\
\text { Specification Designation }\end{array}$ & $\begin{array}{c}\text { ASTM } \\
\text { Specification Designation }\end{array}$ \\
\hline \multicolumn{2}{|c|}{ Carbon Steels } \\
\hline $\begin{array}{l}* * \\
* * \\
* *\end{array}$ & $\begin{array}{l}\text { A } 108 \\
\text { A } 513 \\
\text { A } 519\end{array}$ \\
\hline
\end{tabular}

** No corresponding ASME specification has been established. 
Table 2.5 Types and forms of corrosion.

\section{General Corrosion}

Atmospheric corrosion

Galvanic corrosion

Stray-current corrosion

General biological corrosion

Molten salt corrosion

Corrosion in liquid metals

High-temperature corrosion

Oxidation

Sulfidation

Carburization

Hydrogen effects

Hot corrosion

\section{Localized Corrosion}

Filiform corrosion

Crevice corrosion

Pitting corrosion

Localized biological corrosion

\section{Metallurgically Influenced Corrosion}

Intergranular corrosion

Dealloying corrosion

\section{Mechanically Assisted Degradation}

Erosion corrosion

Fretting corrosion

Cavitation and water drop impingement

Corrosion fatigue

\section{Environmentally Induced Cracking}

Stress-corrosion cracking

Hydrogen damage

Liquid metal embrittlement

Solid metal induced embrittlement

Source: "Volume 13 - Corrosion," ASM Handbook, formerly ninth edition, Metals Handbook, ASM INTERNATIONAL, Materials Park, Ohio, September 1987. 
Table 2.6 Aqueous environments that could potentially cause stress-corrosion cracking of containment steels.

Low-Carbon and Low-Alloy Ferritic Steels

Nitrites

Phosphates

Sulfates

Carbonates

Carbon monoxide

Carbon dioxide

Hydrogen sulfide

Ferric chloride

Ammonia

Organic liquids

Water/oxygen

Cyanides

Hydroxides
Austenitic Stainless Steels

Chlorides

Hydroxides

Fluorides

Bromides

Water/oxygen

Sulfates

Thiocyanates

Thiosulfates

Tetrathionates

Polythionates

Sulfur dioxide

Sulfurous acid

Source: "Volume 1 - Properties and Selection: Irons, Steels, and High-Performance Alloys," Metals Handbook, Tenth Edition, ASM INTERNATIONAL, Materials Park, Ohio, March 1990. 


\section{CLASSIFICATION AND DESIGNATIONS OF CONTAINMENT STEELS}

\subsection{TYPES OF STEELS}

Ferrous metals are composed of iron and carbon plus other elements that are either introduced during the manufacturing process as part of the raw materials or intentionally added as alloying elements. Steel is a common ferrous metal that is used extensively in the construction industry because it can be manufactured relatively inexpensively in large quantities in accordance with standard specifications. The properties of steel can be varied over a wide range by the addition of carbon and alloying elements and by heat treatment and mechanical operations. Many different systems for classifying ferrous alloys have been developed to organize and characterize the various types of steels included in this material group. Classification systems for steels are typically based on either chemical composition, manufacturing methods, finishing methods, product forms, deoxidation practice, microstructure, required strength levels, heat treatment, or quality descriptors (Ref. 3.1). However, the most widely used classification systems generally reflect chemical composition.

The alloy content of steel is typically determined using a sample of molten metal removed from the ladle or furnace. Results of the chemical analysis are considered to be an accurate representation of the entire heat of steel. Alloy contents of products made from large heats of steel can also be determined, but the variability of these results tends to be somewhat greater that the corresponding heat analysis results. Depending on the alloying elements that are present, ferrous alloys are generally classified as either carbon, low-alloy, or high-alloy steels. Additional designations such as low-carbon, medium-carbon, high-carbon, corrosion-resistant, heat-resistant, and wearresistant are sometimes used to subdivide steels with similar compositions or characteristics. Criteria for assigning these designations are often established arbitrarily based on material composition and maximum and minimum limits for specific chemical elements. Chemical elements that are sometimes present in ferrous alloys are listed in Table 3.1. In general, carbon steels contain at least $\mathbf{0 . 1 2}$ percent carbon, low-alloy steels contain up to ten percent alloying elements, and highalloy steels contain at least ten percent alloying elements.

\subsubsection{Carbon Steels}

Most ferrous alloys produced and shipped in the United States are carbon steels. In general, carbon steels contain up to two percent total alloying elements. Low-carbon steels contain up to $\mathbf{0 . 3 0}$ percent carbon and are used primarily to make flat-rolled products including sheets and strips that can be easily formed into automobile body panels, plates, and shapes for structural applications. Medium-carbon steels contain from 0.30 to 0.60 percent carbon and from 0.60 to 1.65 percent manganese. Rails, railway wheels, rail axles, shafts, couplings, gears, and forgings are products commonly manufactured from medium-carbon steels. Some medium-carbon steels with improved strengths are used in the quenched and tempered condition. High-carbon steels contain at least 0.60 percent carbon and having manganese contents that range from 0.30 to 0.90 percent. High-strength wires and springs are usually manufactured using high-carbon steel.

\subsubsection{Low-Alloy Steels}

Low-alloy steels tend to exhibit mechanical properties that are superior to plain carbon steels. Differences in performance are due primarily to the addition of alloying elements such as nickel, chromium, and molybdenum. In general, alloy contents for these steels range from about two to ten percent. Terms commonly used to identify and characterize low-alloy steels include low-carbon quenched and tempered steels, medium-carbon ultrahigh-strength steels, bearing steels, chromium-molybdenum heat-resistant steels, and high-strength low-alloy steels (HSLA). 


\subsubsection{High-Alloy Steels}

High-alloy steels include a broad family of materials known as stainless steels. Stainless steels are iron-based alloys that contain at least 10.5 percent chromium (Ref. 3.1). Corrosion resistance and extreme-temperature mechanical properties are the most important characteristics of stainless steels. Terms commonly used to identify different types of stainless steels include martensitic, ferritic, austenitic, duplex (ferritic-austenitic), and precipitation hardening.

Martensitic stainless steels have a body-centered cubic (bcc) crystalline structure (martensitic) and chromium contents ranging from about 10.5 to 18 percent. Generally resistant to relatively mild environments, these steels can be hardened by heat treating to increase wear resistance or to maintain cutting edges. Martensitic steels are rarely used as construction materials for pressure vessel components.

Ferritic stainless steels also have a bcc crystalline structure, but the chromium content for these steels ranges from 10.5 to about 30 percent. Compared to austenitic stainless steels, the high-temperature strengths of ferritic stainless steels are relatively poor and toughness is somewhat limited at low temperatures. Ferritic steels cannot be hardened by heat treatment.

Austenitic stainless steels have a face-centered cubic (fcc) crystalline structure (austenite) resulting from the addition of austenitizing elements such as nickle, manganese, and nitrogen. Essentially nonmagnetic, austenitic stainless steels are highly resistant to corrosion at temperatures up to $815^{\circ} \mathrm{C}\left(1,500^{\circ} \mathrm{F}\right)$, can only be hardened by cold working, and possess high impact strength at low temperatures. The chromium content ranges from 16 to 26 percent and the nickle content may approach 35 percent. Properties of austenitic stainless steels are generally excellent at cryogenic temperatures and strengths are good at high temperatures.

Duplex stainless steels have a mixture of bcc and fcc crystalline structures. Compared to austenitic stainless steels, the corrosion resistance of duplex stainless steels are about the same, but the the tensile and yield strengths are higher and the resistance to stress-corrosion cracking is improved.

Precipitation-hardening stainless steels are chromium-nickel alloys that contain precipitation hardening elements such as copper, aluminum, and titanium. These steels attain high strength by precipitation hardening of the martensitic structure.

\subsection{STEEL DESIGNATIONS}

Steel is routinely identified by a combination of numbers, letters, symbols, or names that designate its class, type, and grade. This identifier may be a simple specification designation such as ASTM A 240, Type 304L (Ref. 3.2), or a complex series of designations that reflect categories of information pertaining to composition, processing history, end use, and service history. Some of the designation systems that are used in the United States to distinguish one steel from another are described in the following sections.

\subsubsection{ASTM and ASME Material Specifications}

ASTM has adopted a unique serial designation system for its material specifications. Each designation includes a capital letter (A for ferrous metals) followed by a serial number (one to four digits). When a material specification contains chemical or strength requirements for more than one material, its designation is supplemented with an additional term such as Grade 35, Type A, or Class 1. Occasionally, material specifications such as ASTM A 695 cover many materials. Unique identity for each material covered by these specifications is achieved by using two supple- 
mental terms. For example, steels that conform to ASTM A 695 requirements include both Type and Grade designations (Ref. 3.3).

The designation system adopted by ASME for its material specifications is very similar to the one adopted by ASTM. ASME material specification designations use the prefix "S" followed immediately by the complete ASTM material specification designation. A comparison of the ASTM and ASME designation systems was presented in Sect. 2.2. In general, ASME material specifications are either identical to or modified versions of specifications adopted by ASTM. Tables 2.1 to 2.4 contain lists of ASME and ASTM material specifications permitted for use in construction of containment pressure boundary components.

\subsubsection{Unified Numbering System (UNS)}

A unified numbering system (UNS) for metals and alloys has been established by ASTM. This system provides a means for correlating many nationally used numbering systems administered by different societies, trade associations, and material producers. Procedures for establishing six-character alphanumeric UNS designations for different families of metals and alloys are including in ASTM E 527 (Ref. 3.4). Each UNS designation consists of a capital letter followed by a five-digit number. Alphabet designations for eight categories of ferrous metals and alloys have been established and ranges of five-digit numbers for these materials have been assigned. In general, high-alloy steels are more likely to have been assigned UNS designations than low-alloy or carbon steels. Consequently, not all of the steels listed in Tables 2.1 to 2.4 can be represented by UNS designations.

The following example illustrates the relationship between UNS, ASTM, and ASME material specification designations for a common type of stainless steel. The UNS designation for high-alloy austenitic stainless steel conforming to ASTM A 240, Type 304L requirements is S30403 (Ref. 3.2). Steel that conforms to ASME SA-240, Type 304L requirements (Ref. 3.5) can also be represented by S30403 because specifications ASTM A 240 and ASME SA-240 are identical.

\subsubsection{Metal and Alloy Identification Standard}

Material specifications and UNS designations generally provide relatively simple yet effective ways to distinguish one metal from another. However, when data and information from many different sources are compiled and stored in a computerized data base, additional identification parameters are often required to establish a unique identity for the material. Unique identification is also required for efficient retrieval of information and to allow meaningful comparisons of data from different sources.

A standard guide for the identification of metals and alloys in computerized materials property data bases has been adopted by ASTM. This guide, ASTM E 1338 (Ref. 3.6), contains a sample data format that includes 37 information fields considered necessary for the generic identification of metals and alloys. The information fields in the guide are subdivided into eight data segments that represent (1) primary identifiers, (2) specifications, (3) characterization, (4) material source, (5) processing history, (6) part details, (7) fabrication and service history, and (8) supplemental information. Certain of these information fields are essential for the data base to be complete while others represent information that is considered desirable. In general, as the amount of essential and desirable information reported for a particular material increases, the uncertainty and confusion related to identification of a specific material decrease. 


\subsection{MATERIAL CODES}

Each containment steel considered at the Structural Materials Information Center will be assigned a unique seven-character Material Code that will be used consistently in Chapter 6 of the Structural Materials Handbook and in the CONTAIN.DB Structural Materials Electronic Data Base file as a material identifier. The material code concept has been adopted because it provides a convenient way to categorize and organize materials based on compositional and processing information rather than simply by material specification designations. In some ways, material codes are similar to UNS designations because both systems refer to a particular material that may conform to more than one material specification. However, material codes do not represent as many parameters as the metal and alloy identification system described in Sect. 3.2.3.

Figure 3.1 shows a typical material code arrangement for a low-alloy carbon steel plate material permitted for use in construction of containment pressure boundary components. The first two characters of the material code are the Chapter Index. This two-digit number corresponds to the chapter in the handbook where properties for this material are reported. The chapter index for steels used to construct containment pressure boundary components is 06 . The second parameter (third character in the material code) is the Group Index. This single-letter designation is used to subdivide materials in Chapter 6 into groups of materials with common compositional characteristics. Carbon and low-alloy steels will be assigned to the ' $A$ ' group index and stainless steels will be assigned to the ' $B$ ' group index. The third parameter (fourth character in the material code) is the Class Index This single-letter designation is used to organize materials with the same group index into types of materials that have the same form or processing history. Table 3.2 shows the various class indexes that will be used to establish material codes for containment steels. The fourth parameter (fifth, sixth, and seventh characters in the material code) is the Identifier Index. Identifiers are three-digit numbers that range from 000 to 999 . They are used to distinguish materials within the same group and class from each other.

\subsection{REFERENCES}

3.1 "Volume 1 - Properties and Selection: Irons, Steels, and High-Performance Alloys," Metals Handbook, Tenth Edition, ASM INTERNATIONAL, Materials Park, Ohio, March 1990.

3.2 "Standard Specification for Heat-Resistant Chromium and Chromium-Nickel Stainless Steel, Plate, Sheet, and Strip for Pressure Vessels," ASTM Designation: A 240-89b, 1990 Annual Book of ASTM Standards, Vol. 01.03, American Society for Testing and Materials, Philadelphia, Pennsylvania, 1990, pp. 37-41.

3.3 "Standard Specification for Steel Bars, Carbon, Hot-Wrought, Special Quality, for Fluid Power Applications," ASTM Designation: A 695-81, 1990 Annual Book of ASTM Standards, Vol. 01.05, American Society for Testing and Materials, Philadelphia, Pennsylvania, 1990, pp. 477-478.

3.4 "Standard Practice for Numbering Metals and Alloys (UNS)," ASTM Designation: E 52783, 1990 Annual Book of ASTM Standards, Vol. 01.05, American Society for Testing and Materials, Philadelphia, Pennsylvania, 1990, pp. 625-630.

3.5 "Materials," ASME Boiler and Pressure Vessel Code, Section I, Part A - Ferrous Materials Specifications, American Society of Mechanical Engineers, New York, New York, July 1, 1992. 
3.6 "Standard Guide for The Identification of Metals and Alloys in Computerized Material Property Databases," ASTM Designation: E 1338-90, 1991 Annual Book of ASTM Standards, Vol. 14.01, American Society for Testing and Materials, Philadelphia, Pennsylvania, 1991. 


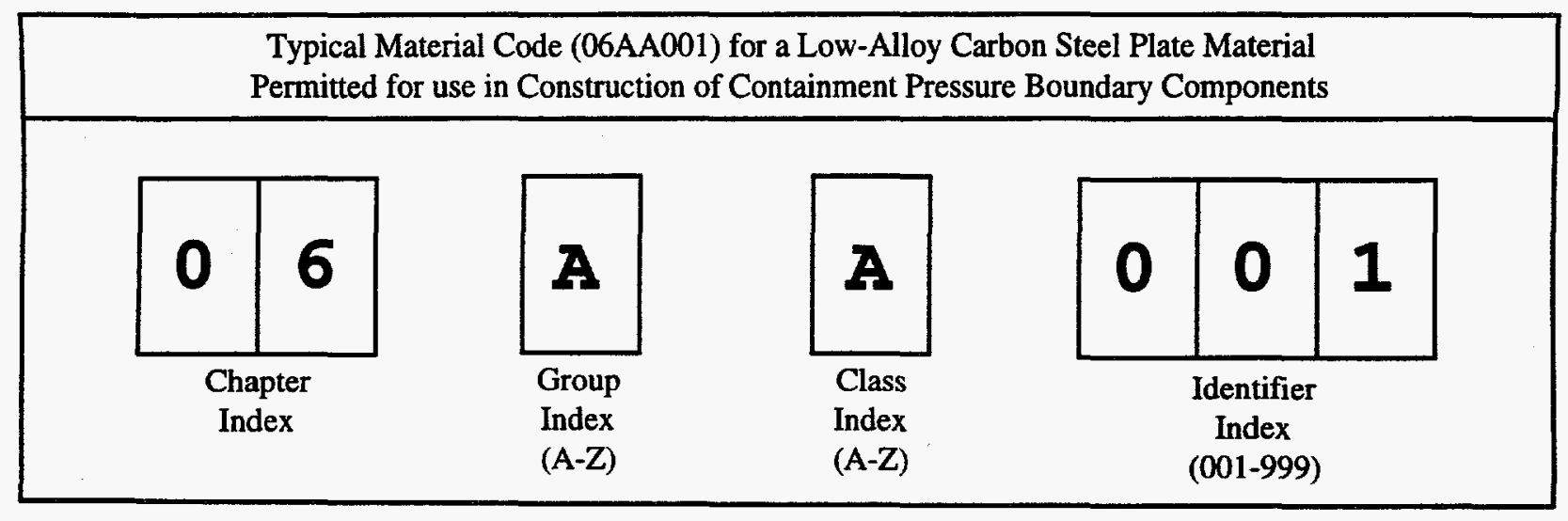

Fig. 3.1 Material code arrangement for containment steels. 
Table 3.1 Chemical elements that are sometimes present in containment steels.

Abbreviation

Al

B

C

$\mathrm{Cr}$

Co

$\mathrm{Cu}$

$\mathrm{Fe}$

$\mathrm{Pb}$

$\mathrm{Mn}$

Mo

$\mathrm{Ni}$

$\mathrm{Nb}$

$\mathrm{N}$

$P$

Se

$\mathrm{Si}$

S

Ti

W

V
Chemical Element

Aluminum

Boron

Carbon

Chromium

Cobalt

Copper

Iron

Lead

Manganese

Molybdenum

Nickel

Niobium

Nitrogen

Phosphorus

Selenium

Silicon

Sulfur

Titanium

Tungsten

Vanadium

Zirconium 
Table 3.2 Class indexes for containment steels.

\section{Class Index}

A

B

C

D

E

\section{Characteristic Feature}

Hot- or cold-rolled plates, shapes, bars, sheets, and strips

Forgings and castings

Pipes, tubes, and, fittings

Bolting materials

Special materials 


\section{MATERIAL PROPERTIES AND DATA}

\subsection{MECHANICAL PROPERTIES}

Structural integrity and load-carrying capacity of containment pressure boundary components are influenced by the mechanical properties of the construction materials. Changes in material properties resulting from exposure to extreme temperatures or severe environments can also affect component performance. Test methods for determining the mechanical properties of steel products have been established by ASTM and adopted by ASME (Refs. 4.1 and 4.2) even though the Code rules (Refs. 4.3 and 4.4) do not require testing of production materials to establish property values for use in design calculations. Values for this purpose are tabulated in Section II, Part D, Subparts 1 and 2 of the Code (Ref. 4.5). Six tables in Subpart 1 contain maximum allowable stress, design stress intensity, tensile strength, and yield strength values for ferrous materials for temperatures ranging in some cases from as low as $-198^{\circ} \mathrm{C}\left(-325^{\circ} \mathrm{F}\right)$ to as high as $816^{\circ} \mathrm{C}$ $\left(1,500^{\circ} \mathrm{F}\right)$ in others. Materials included in the tables are organized according to their nominal composition and identified by their ASME material specification designations. Another table in Subpart 2 contains modulus of elasticity values for ferrous materials for temperatures ranging from -198 to $482^{\circ} \mathrm{C}\left(-325\right.$ to $\left.900^{\circ} \mathrm{F}\right)$.

\subsubsection{Elastic Properties}

Modulus of elasticity, shear modulus, and Poisson's ratio are considered elastic material properties. Modulus of elasticity, also known as Young's modulus, is the ratio of stress to corresponding strain below the proportional limit. For many materials the stress-strain relationship does not conform to Hooke's law throughout the entire elastic range. In these cases, terms such as initial tangent modulus, tangent modulus, secant modulus, and cord modulus are often used to designate modulus of elasticity. Shear modulus is the ratio of shear stress to corresponding shear strain below the proportional limit. Poisson's ratio is the ratio of transverse strain to the corresponding axial strain resulting from uniformly distributed axial stress that is below the proportional limit (Ref. 4.6).

Elastic property values for steels can be determined from test results in which specimens are loaded in either tension or compression while deflection or elongation measurements are taken (Refs. 4.7 to 4.9 ). These tests are usually conducted at room temperature, but testing at other temperatures is occasionally performed because material composition and exposure temperatures influence elastic properties of ferrous materials. Results from these tests can be represented on a stress-strain diagram in which values of stress are plotted against corresponding values of strain. For isotropic materials, modulus of elasticity $(E)$, Poisson's Ratio $(\mu)$, and shear modulus $(G)$ can be related using the following equation:

$$
\mu=(\mathrm{E} / 2 \mathrm{G})-1
$$

In general, maximum or minimum elastic property values are not contained in material specifications. Consequently, these values are not determined routinely. Nominal or typical modulus of elasticity values for use in engineering calculations are often obtained from information sources such as handbooks, references, and building codes. The Code provides modulus of elasticity values for use in design of pressure retaining components. According to Table TM-1 (Ref. 4.5), values of the modulus of elasticity of room-temperature $\left[21^{\circ} \mathrm{C}\left(70^{\circ} \mathrm{F}\right)\right]$ steels range from a high of $213 \mathrm{GPa}(30.9 \mathrm{ksi})$ for steels that contain from five to nine percent chromium to a low of $192 \mathrm{GPa}(27.8 \mathrm{ksi})$ for certain nickel steels. Low-carbon steel with less than 0.30 percent carbon has a tabulated room-temperature modulus of elasticity value of $203 \mathrm{GPa}(29.5 \mathrm{ksi})$. However, the tabulated modulus of elasticity value for this material increases to $217 \mathrm{GPa}$ 
$(31.4 \mathrm{ksi})$ as the temperature decreases to $-198^{\circ} \mathrm{C}\left(-325^{\circ} \mathrm{F}\right)$ and decreases to $154 \mathrm{GPa}(22.4 \mathrm{ksi})$ as the temperature increases to $482^{\circ} \mathrm{C}\left(900^{\circ} \mathrm{F}\right)$.

Because modulus of elasticity values are important material parameters that are used extensively in engineering design and stress analysis applications, baseline room-temperature and temperature-dependent values listed in Table TM-1 will be reported for each containment steel contained in the Structural Materials Information Center. Whenever suitable modulus of elasticity, shear modulus, and Poisson's ratio test data are collected, they will also be included in the data base.

\subsubsection{Strength Properties}

Yield strength, yield point, tensile strength, elongation, and reduction in area are considered strength-related mechanical properties. Test methods for determining these properties for metallic materials have been established by ASTM (Refs. 4.10-4.12). Yield strength is the stress at which a material exhibits a specified limiting deviation from the proportionality of stress to strain. The offset method (usually a strain of 0.2 percent) and the total-extension-under-load method (Ref. 4.6) are often used to establish yield strength values. However, values determined by these two methods may be different depending on the shape of the stress-strain curve. Yield point is the first stress in a material less than the minimum obtainable stress at which an increase in strain occurs without an increase in stress. The yield point is less than the yield strength because most steels are not perfectly elastic-plastic. Tensile strength is the maximum tensile stress a material is capable of sustaining. This value is calculated from the maximum load achieved during a tensile test carried to rupture and the original cross-sectional area of the specimen. Elongation is the increase in gage length of a tension test specimen and is usually expressed as a percentage of the original gage length. Reduction in area is the difference between the original cross-sectional area of a tension test specimen and the area of its smallest cross section measured at or after fracture.

Material specifications generally contain tensile requirements for yield strength, tensile strength, and elongation. For example, the tensile requirements for ASTM A 516, Grade 70 (Ref. 4.13) steel include a minimum tensile strength of $485-620 \mathrm{MPa}(70-90 \mathrm{ksi})$, minimum yield strength of $260 \mathrm{MPa}$ (38 ksi), minimum elongation in $200 \mathrm{~mm}$ ( $8 \mathrm{in}$.) of 17 percent, and minimum elongation in $50 \mathrm{~mm}(2 \mathrm{in}$.) of 21 percent. Tests to verify compliance with material specifications are routinely conducted at room temperature by material manufacturers. It is the responsibility of the user to establish allowable stress limits for particular applications and appropriate property values for other exposure conditions.

Section II, Part D of the Code (Ref. 4.5) contains tables of strength-related property values for use in design of containment pressure boundary components. Each table provides values of maximum permissible stress at a number of corresponding exposure temperatures. Due to material limitations, the temperature range varies from one table to the next, and stress values for certain steels are not reported at every temperature. Table $1 \mathrm{~A}$ of the Code contains maximum allowable stress values for ferrous materials at temperatures ranging from -29 to $816^{\circ} \mathrm{C}\left(-20\right.$ to $\left.1,500^{\circ} \mathrm{F}\right)$, Table 2A contains design stress intensity values for ferrous materials at temperatures ranging from -29 to $482^{\circ} \mathrm{C}\left(-20\right.$ to $\left.900^{\circ} \mathrm{F}\right)$, Table 3 contains maximum allowable stress values for ferrous and nonferrous bolting materials at temperatures ranging from -29 to $816^{\circ} \mathrm{C}\left(-20\right.$ to $\left.1,500^{\circ} \mathrm{F}\right)$, Table 4 contains design stress intensity values for ferrous and nonferrous bolting materials at temperatures ranging from -29 to $427^{\circ} \mathrm{C}\left(-20\right.$ to $\left.800^{\circ} \mathrm{F}\right)$, Table $U$ contains tensile strength values for ferrous and nonferrous materials at temperatures ranging from -29 to $538^{\circ} \mathrm{C}\left(-20\right.$ to $\left.1,000^{\circ} \mathrm{F}\right)$, and Table Y-1 contains yield strength values for ferrous and nonferrous materials at temperatures ranging from -29 to $538^{\circ} \mathrm{C}\left(-20\right.$ to $\left.1,000^{\circ} \mathrm{F}\right)$. 
Temperature-dependent tensile and yield strength values listed in Tables $U$ and $Y-1$ of the Code will be used to develop performance curves for each containment steel contained in the Structural Materials Information Center. These values will be supplemented, whenever possible, with experimental data and test results that are collected. The maximum allowable stress and design stress intensity values listed in these tables will also be included in the data base for reference purposes.

\subsubsection{Fatigue Properties}

Fatigue is defined by ASTM as the process of progressive localized permanent structural change occurring at some point or points in a material subjected to conditions that produce fluctuating stress and stain values that may culminate in cracks or complete fracture after a sufficient number of fluctuations. Low-cycle fatigue is characterized by the presence of macroscopic cyclic plastic strains as evidenced by a stress-strain hysteresis loop (Ref. 4.14). Design fatigue curves for various types of steels are provided in Section III, Division 1, Appendix I of the Code (Ref. 4.15). These curves are for use in analysis for cyclic operation and thermal stress ratchet. However, as discussed in Sect. 2.3.2, fatigue is not expected to be a generic containment issue. Consequently, fatigue properties for containment steels will not be collected at the Structural Materials Information Center and will not be included in the material properties data base.

\subsection{PHYSICAL PROPERTIES}

Thermal expansion, thermal conductivity, and thermal diffusivity are physical properties that can affect the structural response of containment pressure boundary components by influencing the magnitude of thermally induced stresses. Thermal stress is a self-balancing stress produced by nonuniform distribution of temperature or by differing thermal coefficients of expansion. Nominal values for these three properties are provided in Section II, Part D of the Code (Ref. 4.5) for various types of steels.

\subsubsection{Coefficient of Thermal Expansion}

Linear thermal expansion is the change in length per unit length of a material resulting from a change in temperature. For many steels, linear thermal expansion does not remain constant as the difference between two reference temperatures increases. The mean coefficient of linear thermal expansion is obtained by dividing the linear thermal expansion by the change in temperature. For completeness, mean coefficients of linear thermal expansion must be accompanied by the values of the two temperatures used in the calculations. The instantaneous coefficient of linear thermal expansion is the slope of the linear thermal expansion curve at a particular temperature. Again, for completeness, both the instantaneous coefficient of linear thermal expansion and the corresponding temperature must be reported to avoid possible misuse and confusion.

Although two test methods for determining linear thermal expansion of materials have been established by ASTM (Refs. 4.16 and 4.17), mean and instantaneous coefficients of linear thermal expansion are not routinely determined by material producers. Nominal values for various ferrous materials are provided in Table TE-1 (Ref. 4.5). These values are reported at discrete temperatures ranging from 21 to $427^{\circ} \mathrm{C}\left(70\right.$ to $\left.800^{\circ} \mathrm{F}\right)$. At the Structural Materials Information Center, the

nominal room-temperature value listed in Table TE-1 of the Code will be reported as a baseline property for each containment steel included in the data base, and a note will be included in the handbook directing the user to refer to Table TE-1 for other temperature-dependent nominal coefficient of thermal expansion values. 


\subsubsection{Coefficients of Thermal Conductivity and Diffusivity}

Thermal conductivity is the time rate of heat flow through a material under steady state conditions. When the thermal conductivity of a material is high, the thermal gradient throughout a component made using the material is low. Conversely, when the thermal conductivity is low, the thermal gradient is high. Thermal diffusivity is the ratio of thermal conductivity of a material to the product of its density and specific heat capacity. This property represents the rate at which temperature changes within a material can take place. Specific heat capacity is the quantity of heat required to provide a unit temperature increase to a unit mass of a material (Ref. 4.18). Thermal conductivity (TC), thermal diffusivity (TD), specific heat capacity, and density can be related using the following equations:

$$
\mathrm{TD}=\frac{\mathrm{TC}(\mathrm{W} / \mathrm{m} \cdot \mathrm{K})}{\text { Density }\left(\mathrm{kg} / \mathrm{m}^{3}\right) \cdot \text { Specific Heat }(\mathrm{J} / \mathrm{kg} \cdot \mathrm{K})} \mathrm{m}^{2} / \mathrm{s}
$$

or

$$
\mathrm{TD}=\frac{\mathrm{TC}\left(\mathrm{Btu} / \mathrm{hr}^{\circ} \mathrm{ft} \bullet^{\circ} \mathrm{F}\right)}{\text { Density }\left(\mathrm{lb} / \mathrm{ft}^{3}\right) \cdot \text { Specific Heat }\left(\mathrm{Btu} / \mathrm{lb} \bullet^{\circ} \mathrm{F}\right)} \mathrm{ft}^{2} / \mathrm{hr} \text {. }
$$

Test methods for determining thermal conductivity and specific heat capacity of solids have been established by ASTM (Refs. 4.19 and 4.20). However, because thermal properties of steels are not routinely determined by material producers, only nominal thermal conductivity and thermal diffusivity values for various ferrous materials are provided in Table TCD (Ref. 4.5). These values are reported at discrete temperatures ranging from 21 to $816^{\circ} \mathrm{C}\left(70\right.$ to $\left.1,500^{\circ} \mathrm{F}\right)$. At the Structural Materials Information Center, the nominal room-temperature values listed in Table TCD of the Code will be reported as baseline values for each containment steel included in the data base, and a note will be included in the handbook directing the user to refer to Table TCD for other temperature-dependent thermal conductivity and thermal diffusivity values.

\subsection{PROPERTY CODES}

A wide variety of containment steel data and information will be collected at the Structural Materials Information Center and used to develop Structural Materials Handbook pages and Structural Materials Electronic Data Base files. The data base will contain three information categories representing general information, mechanical properties, and physical properties. To ensure material-to-material presentation format consistency and compatibility between handbook and electronic data base entries, four-digit Property Codes will be used to represent individual data fields and specific information entries. Table 4.1 identifies the property code ranges and corresponding property categories covered by each range. A complete listing of property codes and property code descriptions will be included in Volume 4 of the handbook.

\subsubsection{General Information}

General information reported for each containment steel included in the data base will appear in Volume 3 of the handbook as notes and tables. This same information will also be included 
in the electronic data base as notes and data field entries. Table 4.2 lists general information property codes and corresponding property descriptions that will be used to categorize and systematically represent containment steel data and information.

Bibliographic information will also be reported for each containment steel included in the data base. A master list of reference documents and information sources will be compiled at the Structural Materials Information Center and included in Volume 4 of the handbook. Each entry will be numbered consecutively and multiple entries of the same bibliographic information will not be permitted. These numbers will be used consistently throughout the handbook and the electronic data base as reference documentation identifiers and will be synonymous with the bibliographical information they represent.

\subsubsection{Mechanical Properties}

Mechanical properties such as the ones identified in Sect. 4.1 will be reported for each containment steel included in the database. Room-temperature mechanical property values and corresponding property codes will be reported as baseline information. Engineering graphs representing either temperature- or environment-dependent mechanical properties will also be prepared and included in the data base provided suitable data and experimental test results can be collected. Tables 4.3 and 4.4 list property codes and corresponding property descriptions for various mechanical properties and certain types of engineering graphs that could be reported for a particular containment steel. Depending on the types of data and information collected, these lists may need to be expanded to accommodate additional mechanical properties. As a minimum, the tensile requirements provided in the material specifications and the room-temperature property values provided in Section II, Part D of the Code (Ref. 4.5) will be reported in Volume 3 of the handbook and included in the electronic data base. In addition, tensile and yield strength versus temperature graphs will be prepared using tabulated values listed in Section II, Part D.

\subsubsection{Thermal, Physical, and Other Properties}

Thermal, physical, and other properties such as the ones identified in Sect. 4.2 will be reported for each containment steel included in the database. Room-temperature property values and corresponding property codes will be reported as baseline information. Engineering graphs representing temperature- and environment-dependent properties will also be prepared and included, provided suitable data and experimental test results can be collected. As a minimum, the nominal room-temperature coefficient of thermal expansion, thermal conductivity, and thermal diffusivity values provided in Section II, Part D of the Code (Ref. 4.5) will be reported in Volume 3 of the handbook and included in the electronic data base.

\subsection{REFERENCES}

4.1 "Standard Test Methods and Definitions for Mechanical Testing of Steel Products," ASTM Designation: A 370-89, 1990 Annual Book of ASTM Standards, Vol. 01.02, American Society for Testing and Materials, Philadelphia, Pennsylvania, 1990, pp. 168-213.

4.2 "Materials," ASME Boiler and Pressure Vessel Code, Section II, Part A - Ferrous Materials Specifications, American Society of Mechanical Engineers, New York, New York, July 1, 1992.

4.3 "Rules for Construction of Nuclear Power Plant Components," ASME Boiler and Pressure Vessel Code, Section III, Division 1 - Subsection NE, Class MC Components, American Society of Mechanical Engineers, New York, New York, July 1, 1992. 
4.4 "Rules for Construction of Nuclear Power Plant Components," ASME Boiler and Pressure Vessel Code, Section III, Division 2, Code for Concrete Reactor Vessels and Containments, Subsection CC, Concrete Containments (Prestressed or Reinforced), American Society of Mechanical Engineers, New York, New York, July 1, 1992.

4.5 "Materials," ASME Boiler and Pressure Vessel Code, Section II, Part D - Properties, American Society of Mechanical Engineers, New York, New York, July 1, 1992.

4.6 "Standard Definitions of Terms Related to Methods of Mechanical Testing," ASTM Designation: E 6-89, 1991 Annual Book of ASTM Standards, Vol. 03.01, American Society for Testing and Materials, Philadelphia, Pennsylvania, 1991, pp. 93-102.

4.7 "Standard Test Method for Young's Modulus, Tangent Modulus, and Chord Modulus," ASTM Designation: E 111-82, 1991 Annual Book of ASTM Standards, Vol. 03.01, American Society for Testing and Materials, Philadelphia, Pennsylvania, 1991, pp. 274279.

4.8 "Standard Test Method for Shear Modulus at Room Temperature," ASTM Designation: E 147-87, 1991 Annual Book of ASTM Standards, Vol. 03.01, American Society for Testing and Materials, Philadelphia, Pennsylvania, 1991, pp. 336-339.

4.9 "Standard Test Method for Poisson's Ratio at Room Temperature," ASTM Designation: E 147-87, 1991 Annual Book of ASTM Standards, Vol. 03.01, American Society for Testing and Materials, Philadelphia, Pennsylvania, 1991, pp. 306-308.

4.10 "Standard Test Methods of Tension Testing of Metallic Materials," ASTM Designation: E 8-90a, 1991 Annual Book of ASTM Standards, Vol. 03.01, American Society for Testing and Materials, Philadelphia, Pennsylvania, 1991, pp. 130-145.

4.11 "Standard Practice for Elevated Temperature Tension Tests of Metallic Materials," ASTM Designation: E 21-79, 1991 Annual Book of ASTM Standards, Vol. 03.01, American Society for Testing and Materials, Philadelphia, Pennsylvania, 1991, pp. 190-196.

4.12 "Standard Practice for Compression Tests of Metallic Materials at Elevated Temperatures with Conventional or Rapid Heating Rates and Strain Rates," ASTM Designation: E 209-65, 1991 Annual Book of ASTM Standards, Vol. 03.01, American Society for Testing and Materials, Philadelphia, Pennsylvania, 1991, pp. 370-375.

4.13 "Standard Specification for Pressure Vessel Plates, Carbon Steel, for Moderate- and Lower-Temperature Service," ASTM Designation: A 516/A 516M-86, 1990 Annual Book of ASTM Standards, Vol. 01.04, American Society for Testing and Materials, Philadelphia, Pennsylvania, 1990, pp. 320-322.

4.14 "Standard Definition of Terms Relating to Fatigue," ASTM Designation: E 1150-87, 1991 Annual Book of ASTM Standards, Vol. 03.01, American Society for Testing and Materials, Philadelphia, Pennsylvania, 1991, pp. 815-824.

4.15 "Division 1 - Appendices," ASME Boiler and Pressure Vessel Code, Section III, American Society of Mechanical Engineers, New York, New York, July 1, 1992.

4.16 "Standard Test Method for Linear Thermal Expansion of Solid Materials with a Vitreous Silica Dilatometer," ASTM Designation: E 228-85, 1991 Annual Book of ASTM Standards, Vol. 03.01, American Society for Testing and Materials, Philadelphia, Pennsylvania, 1991, pp. 376-380. 
4.17 "Standard Test Method for Linear Thermal Expansion of Rigid Solids with Interferometry," ASTM Designation: E 289-70, 1991 Annual Book of ASTM Standards, Vol. 03.01, American Society for Testing and Materials, Philadelphia, Pennsylvania, 1991, pp. 402-408.

4.18 "Standard Terminology Relating to Thermophysical Properties," ASTM Designation: E 1142-90a, 1991 Annual Book of ASTM Standards, Vol. 14.01, American Society for Testing and Materials, Philadelphia, Pennsylvania, 1991, pp. 722-726.

4.19 "Standard Test Method for Thermal Conductivity of Solids by Means of the GuardedComparative-Longitudinal Heat Flow Technique," ASTM Designation: E 1225-87, 1991 Annual Book of ASTM Standards, Vol. 14.01, American Society for Testing and Materials, Philadelphia, Pennsylvania, 1991, pp. 754-763.

4.20 "Standard Test Method for Determining Specific Heat Capacity by Differential Scanning Calorimetry," ASTM Designation: E 1269-90, 1991 Annual Book of ASTM Standards, Vol. 14.01, American Society for Testing and Materials, Philadelphia, Pennsylvania, 1991, pp. 802-806. 
Table 4.1 Material property code ranges and descriptions.

\begin{tabular}{lll}
\hline Property Code Ranges & & Property Code Range Description \\
\hline $1000-1999$ & & General Information \\
$2000-2999$ & & Reserved for use with Concrete \\
$3000-3999$ & Mechanical Properties \\
$4000-4999$ & Thermal, Physical, and Other Properties \\
$5000-9999$ & Available for Data Base Expansion \\
\hline
\end{tabular}


Table 4.2 General information property codes.

\begin{tabular}{|c|c|c|}
\hline Property Code & Description & Types of Data and Information \\
\hline 1010 & Descriptive Information & $\begin{array}{l}\text { Introductory and background comments } \\
\text { including material specification designa- } \\
\text { tions, specification exceptions, and UNS } \\
\text { designations (if available) }\end{array}$ \\
\hline 1110 & Material Characteristics & $\begin{array}{l}\text { Material applications, fabrication practices, } \\
\text { available product forms, notes, and } \\
\text { comments }\end{array}$ \\
\hline 1210 & Material Composition & $\begin{array}{l}\text { Chemical requirements contained in } \\
\text { material specifications, notes, and } \\
\text { comments }\end{array}$ \\
\hline 1220 & Processing Information & $\begin{array}{l}\text { Manufacturing, heat treatment, quality, } \\
\text { marking, weight, supplementary, and other } \\
\text { requirements contained in the material } \\
\text { specification }\end{array}$ \\
\hline 1230 & Welding Information & Weldability and welding procedures \\
\hline 1310 & Baseline Information & $\begin{array}{l}\text { Room-temperature reference mechanical, } \\
\text { thermal, physical, and other property } \\
\text { values, notes, and comments }\end{array}$ \\
\hline 1320 & Dimensional Standards & $\begin{array}{l}\text { Dimensional standards contained in } \\
\text { material specifications }\end{array}$ \\
\hline
\end{tabular}


Table 4.3 Property codes for mechanical property values of containment steels.

\begin{tabular}{|c|c|c|c|}
\hline \multirow{2}{*}{$\begin{array}{l}\text { Property } \\
\text { Code }\end{array}$} & \multicolumn{2}{|c|}{ Units } & \multirow{2}{*}{ Property Description } \\
\hline & Metric & Customary & \\
\hline $3100-3199$ & & & $\begin{array}{l}\text { Static Mechanical Properties of } \\
\text { Metallic Materials }\end{array}$ \\
\hline $3100-3109$ & & & Modulus of Elasticity \\
\hline 3101 & $\mathrm{GPa}$ & ksi & Young's Modulus of Elasticity \\
\hline 3102 & $\mathrm{GPa}$ & $\mathrm{ksi}$ & Strain-Hardening Modulus \\
\hline 3103 & $\mathrm{GPa}$ & ksi & Shear Modulus \\
\hline $3110-3119$ & & & Poisson's Ratio \\
\hline 3111 & - & - & Poisson's Ratio \\
\hline $3120-3129$ & & & Ultimate Strength \\
\hline 3121 & $\mathrm{MPa}$ & $\mathrm{ksi}$ & Ultimate Tensile Strength \\
\hline 3122 & $\mathrm{MPa}$ & $\mathrm{ksi}$ & Breaking Tensile Strength \\
\hline 3123 & $\mathrm{MPa}$ & ksi & Ultimate Compressive Strength \\
\hline $3130-3139$ & & & Yield Strength \\
\hline 3131 & $\mathrm{MPa}$ & ksi & Tensile Yield Point \\
\hline 3132 & $\mathrm{MPa}$ & ksi & Tensile Yield Strength \\
\hline 3133 & $\mathrm{MPa}$ & ksi & Compressive Yield Point \\
\hline 3134 & $\mathrm{MPa}$ & ksi & Compressive Yield Strength \\
\hline $3140-3149$ & & & Shear Strength \\
\hline 3141 & $\mathrm{MPa}$ & ksi & Shear Yield Strength \\
\hline 3142 & $\mathrm{MPa}$ & ksi & Ultimate Shear Strength \\
\hline $3150-3159$ & & & Elongation \\
\hline 3151 & $\%$ & $\%$ & $\begin{array}{l}\text { Tensile Elongation } \\
\text { in } 51 \mathrm{~mm}(2 \mathrm{in} .)\end{array}$ \\
\hline 3152 & $\%$ & $\%$ & $\begin{array}{l}\text { Tensile Elongation } \\
\text { in } 203 \mathrm{~mm}(8 \mathrm{in} .)\end{array}$ \\
\hline 3153 & - & - & $\begin{array}{l}\text { Bending Test Elongation } \\
\text { (diameter/thickness ratio) }\end{array}$ \\
\hline 3154 & - & - & Bending Test Elongation \\
\hline & $\%$ & $\%$ & $\begin{array}{l}\text { (pin dia. = value } \bullet \text { bar dia.) } \\
\text { Tensile Elongation }\end{array}$ \\
\hline כנכ & $\%$ & $\%$ & in $250 \mathrm{~mm}$ (10 in.) \\
\hline
\end{tabular}


Table 4.4 Property codes for mechanical property graphs and plots for containment steels.

\begin{tabular}{|c|c|c|c|}
\hline \multirow{2}{*}{$\begin{array}{l}\text { Property } \\
\text { Code }\end{array}$} & \multicolumn{2}{|c|}{ Units } & \multirow{2}{*}{ Property Description } \\
\hline & Metric & Customary & \\
\hline $3700-3799$ & & & $\begin{array}{l}\text { Plots and Graphs of Mechanical } \\
\text { Properties for Metallic Materials }\end{array}$ \\
\hline $3700-3709$ & & & Stress-Strain Diagram \\
\hline 3701 & $\mathrm{MPa}$ & ksi & $\begin{array}{l}\text { Engineering Stress-Strain Diagram } \\
\text { (Ambient Conditions) }\end{array}$ \\
\hline 3702 & $\mathrm{MPa}$ & ksi & $\begin{array}{l}\text { Engineering Stress-Strain Diagram } \\
\text { (Temperature Dependent) }\end{array}$ \\
\hline 3703 & $\mathrm{MPa}$ & ksi & $\begin{array}{l}\text { True Stress-Strain Diagram } \\
\text { (Ambient Conditions) }\end{array}$ \\
\hline $3710-3719$ & & & Strength \\
\hline 3711 & $\mathrm{MPa}$ & ksi & Tensile Yield Strength \\
\hline 3712 & $\mathrm{MPa}$ & ksi & $\begin{array}{l}\text { Ultimate Tensile Strength } \\
\text { vs Temperature }\end{array}$ \\
\hline 3713 & - & - & $\begin{array}{l}\text { Tensile Yield Strength Ratio } \\
\text { ys Temperature }\end{array}$ \\
\hline 3714 & - & - & $\begin{array}{l}\text { Ultimate Tensile Strength Ratio } \\
\text { vs Temperature }\end{array}$ \\
\hline $3720-3729$ & & & \\
\hline 3721 & $\%$ & $\%$ & $\begin{array}{l}\text { Elongation } \\
\text { vs Temperature }\end{array}$ \\
\hline 3722 & - & - & $\begin{array}{l}\text { Ultimate Tensile Elongation } \\
\text { vs Temperature } \\
\text { Ultimate Tensile Elongation Ratio } \\
\text { vs Temperature }\end{array}$ \\
\hline $\begin{array}{c}3730-3739 \\
3731\end{array}$ & $\mathrm{MPa}$ & ksi & $\begin{array}{l}\text { Fatigue } \\
\text { S-N Diagram }\end{array}$ \\
\hline
\end{tabular}




\section{PLAN FOR COLLECTING AND PRESENTING MATERIAL PROPERTIES}

\subsection{DATA COLLECTION}

Containment steel data and information will be collected at the Structural Materials Information Center from open-literature reports and published references. As a minimum requirement for entry into the data base, general information must be reported for each steel so that a unique material identification can be established and experimental results, test data, or nominal property values must be available. Mechanical and physical property values provided in Section II, Part D of the Code (Ref. 5.1) will be used to supplement data and information that are collected.

Three other approaches potentially will be used to expand the data base. One approach will focus on pursuing technical information exchanges with U.S. and foreign research establishments. The second approach will concentrate on developing material properties using prototypical material samples obtained from existing containments. The third approach is an analytical-experimental research effort that relies on accelerated aging tests.

\subsubsection{Technology Exchange}

Research establishments in the U.S., Canada, Europe, and Japan will be contacted in an effort to identify information sources and material property values. Selected governmental agencies that are responsible for design, maintenance, and repair of nuclear structures will be contacted along with universities and private research organizations that perform material testing. As a result of these domestic and foreign contacts, it is expected that reports on containment steel properties will be obtained and lines of communications will be established thereby enhancing the opportunity for further cooperation and technological exchanges.

\subsubsection{Prototypical Material Procurement}

In order to replace the steam generators at the Palisades nuclear power station, a large section of the prestressed concrete containment wall was removed to provide the necessary access. This was accomplished by detensioning and removing some of the unbonded post-tensioning tendons, sawing through the concrete wall, reinforcing bars, tendon ducts, and steel liner, and removing about a 60-cubic-meter section of the containment. After the steam generators were replaced, new liner plate was welded into place, reinforcing bars and tendon ducts were reconnected, concrete was cast, and the post-tensioning tendons were reinstalled and retensioned. The 60-cubicmeter containment wall section was removed in three pieces. Two smaller sections were cut and removed first so that beams could be installed through the containment wall to support the weight of the larger section. After the larger section was withdrawn and lowered to the ground, it was transported to a storage site within the plant boundary. The two smaller sections were shipped to ORNL for future testing and evaluation.

Efforts to obtain prototypical materials from other metal and concrete containments will be undertaken at the Structural Materials Information Center. Prototypical materials are considered valuable because they can be evaluated and tested to quantify effects of aging on containment steel properties. Data obtained from prototypical material sample testing can also be used to enhance the data base. Potential sources of prototypical materials include commercial nuclear power plants like Palisade where sections of the containment were removed, Department of Energy nuclear facilities that are being modified or demolished, and industrial facilities that have appropriate materials and similar environmental exposure conditions. 


\subsubsection{Accelerated Aging Tests}

Mechanical properties of containment steels could also be developed from accelerated aging tests using analytical-experimental procedures. This approach is based on established research procedures that involve three separate phases: (1) problem definition; (2) design of predictive service life test methods to simulate accelerated aging or prolonged exposure to degrading environmental conditions; and (3) mathematical model development.

\subsection{DATA BASE PREPARATION}

Although data collection will be a continuing research effort for the duration of the steel containments and liners program, data and information currently available at the Structural Materials Information Center will be used to begin development of Structural Materials Handbook pages and Structural Materials Electronic Data Base files for the steels listed in Table 5.1. This list was compiled from information contained in Final Safety Analysis Reports (FSARs) representing both BWR and PWR plant types (e.g., BWR Mark I, PWR reinforced or post-tensioned concrete, and PWR cylindrical steel with ice condensers).

The materials listed in Table 5.1 represent only a small number of the steels permitted by the 1992 Boiler and Pressure Vessel Code (Refs. 5.2 and 5.3) for use in construction of containment pressure boundary components. A complete list of carbon, low-alloy, and stainless steels permitted for this purpose is presented in Tables 5.2 to 5.10. These materials represent the five classes of steels listed in Table 3.2 that will be included in the data base. Other steels such as ASTM A 212* (Ref. 5.4) that were permitted in earlier versions of the Code may be added to these lists, particularly if it is learned that these materials were used to construct pressure boundary components in existing containments.

Handbook pages and electronic data base files for each containment steel listed in Tables 5.2 to 5.10 will probably not be prepared due to unavailability of data and information and similarities in chemical composition and tensile strength requirements. Data base developmental efforts will initially focus on carbon and low-alloy steels used to construct containment shells.

\subsection{EXAMPLE HANDBOOK PAGES}

Appendix A contains sample Structural Materials Handbook pages that were prepared for ASME SA-36 (Ref. 5.5) steel. These pages illustrate the presentation format that will be used for each containment steels included in the data base. The material code assigned to ASME SA-36 steel is 06AA001. Material codes for other containment steels are listed in Tables 5.2 to 5.10.

Handbook pages in Volume 1 contain an engineering graph of tensile yield strength ratio versus temperature (Property Code 3713), mathematical equations that were used to generate the performance curve shown on the graph, and tensile yield strength values computed at selected temperatures using the minimum specified tensile yield point of $248 \mathrm{MPa}(36 \mathrm{ksi})$. Volume 2 includes a brief discussion about the information contained in each reference source; an evaluation of the quality of the supporting data and values used to develop the tensile yield strength ratio versus temperature graph; tables of experimental data, test results, and temperature-dependent values provided in Section II, Part D of the Code (Ref. 5.1); an engineering graph of tensile yield strength ratio versus temperature that was prepared using the tabulated data and values; and mathematical equations that were used to generate the performance curve shown on the graph. Volume 3 con-

* Material specification ASME SA-212 was identical to ASTM A 212. In 1964, ASTM A 212 was replaced by ASTM A 515. 
tains general information (Property Code 1000) about ASME SA-36 steel. The types of information presented in each general information category are described in Sect. 4.3.1.

Pages in Volumes 1 and 2 are numbered using an X.X format. The digits that precedes the decimal point (e.g. 1, 2, etc.) corresponds to the property being reported. Digits following the decimal point are used to consecutively number the pages in the data set. This unique page numbering system was adopted so that additional pages for other properties such as ultimate tensile strength ratio versus temperature (Property Code 3714) could be easily added to the handbook. Pages in Volume 3 are numbered consecutively.

Each graph that appears in Volume 1 and 2 will be prepared using EnPlot software (Ref. 5.6). The graph appearing in Volume 2 will also be included in the Structural Materials Electronic Data Base and can be viewed by accessing CONTAIN.DB using Mat.DB (Ref. 5.7). Additional information about the handbook and electronic data base presentation formats is provided in reports that were prepared at ORNL as part of the Structural Aging (SAG) Program (Refs. 5.8 to 5.10 ).

\subsection{REFERENCES}

5.1 "Materials," ASME Boiler and Pressure Vessel Code, Section II, Part D - Properties, American Society of Mechanical Engineers, New York, New York, July 1, 1992.

5.2 "Rules for Construction of Nuclear Power Plant Components," ASME Boiler and Pressure Vessel Code, Section III, Division 1 - Subsection NE, Class MC Components, American Society of Mechanical Engineers, New York, New York, July 1, 1992.

5.3 "Rules for Construction of Nuclear Power Plant Components," ASME Boiler and Pressure Vessel Code, Section III, Division 2, Code for Concrete Reactor Vessels and Containments, Subsection CC, Concrete Containments (Prestressed or Reinforced), American Society of Mechanical Engineers, New York, New York, July 1, 1992.

5.4 "Tentative Specification for High Tensile Strength Carbon-Silicon Steel for Boilers and Other Pressure Vessels," ASTM Designation: A 212-61T, 1961 Annual Book of ASTM Standards, Part 1, American Society for Testing and Materials, Philadelphia, Pennsylvania, September 1961, pp. 435-452.

5.5 "Materials," ASME Boiler and Pressure Vessel Code, Section II, Part A - Ferrous Materials Specifications, American Society of Mechanical Engineers, New York, New York, July 1, 1992.

5.6 EnPlot, Version 3.5, ASM International, ASM/Center for Materials Data, Materials Park, Ohio, 1993.

5.7 Mat.DB, Version 1.22, ASM International, ASM/Center for Materials Data, Materials Park, Ohio, 1992.

5.8 Oland, C. B., Marchbanks, M. F., and Naus, D. J., Plan for Use in Development of the Structural Materials Information Center, ORNL/TR-89/8, Martin Marietta Energy System, Inc., Oak Ridge National Laboratory, Oak Ridge, Tennessee, September, 1989.

5.9 Oland, C. B. and Naus, D. J., Structural Materials Information Center for Presentation of the Time Variation of Material Properties, ORNL/NRC/LTR-90/22, Martin Marietta Energy System, Inc., Oak Ridge National Laboratory, Oak Ridge, Tennessee, November 1990. 
5.10 Oland, C. B. and Naus, D. J., Summary of Materials Contained in the Structural Materials Information Center, ORNL/LTR-94/22, Martin Marietta Energy System, Inc., Oak Ridge National Laboratory, Oak Ridge, Tennessee, July, 1994. 
Table 5.1 Steels used to construct metal and concrete containment pressure boundary components.

ASME SA-285

ASME SA-333

ASME SA-442

ASME SA-516

ASME SA-537 
Table 5.2 Carbon and low-alloy steel plates, shapes, and bars permitted for use in construction of containment pressure boundary components.

\begin{tabular}{|c|c|c|c|}
\hline $\begin{array}{c}\text { Material } \\
\text { Code }\end{array}$ & $\begin{array}{c}\text { ASME } \\
\text { Material } \\
\text { Specification } \\
\text { Designation }\end{array}$ & $\begin{array}{c}\text { ASTM } \\
\text { Material } \\
\text { Specification } \\
\text { Designation }\end{array}$ & $\begin{array}{l}\text { Ietal (MC) } \\
\text { or } \\
\text { ncrete (CC) } \\
\text { ntainments }\end{array}$ \\
\hline \multicolumn{4}{|c|}{ Plates, Shapes, and Bars } \\
\hline 06AA001 & SA-36 & A 36 & $\mathrm{MC}, \mathrm{CC}$ \\
\hline $\begin{array}{l}\text { 06AA002 } \\
\text { 06AA003 } \\
\text { 06AA004 }\end{array}$ & $\begin{array}{l}\text { SA-285, Gr. A } \\
\text { SA-285, Gr. B } \\
\text { SA-285, Gr. C }\end{array}$ & $\begin{array}{l}\text { A } 285, \text { Gr. A } \\
\text { A } 285, \text { Gr. B } \\
\text { A } 285, \text { Gr. C }\end{array}$ & $\begin{array}{l}\mathrm{CC} \\
\mathrm{CC} \\
\mathrm{CC}\end{array}$ \\
\hline 06AA005 & SA-299 & A 299 & $\mathrm{MC}, \mathrm{CC}$ \\
\hline $\begin{array}{l}\text { 06AA006 } \\
\text { 06AA007 }\end{array}$ & $\begin{array}{l}\text { SA-442, Gr. } 55 \\
\text { SA-442, Gr. } 60\end{array}$ & $\begin{array}{l}\text { A } 442, \text { Gr. } 55 \\
\text { A } 442, \text { Gr. } 60\end{array}$ & $\begin{array}{l}\mathrm{MC}, \mathrm{CC} \\
\mathrm{MC}, \mathrm{CC}\end{array}$ \\
\hline $\begin{array}{l}\text { 06AA008 } \\
\text { 06AA009 } \\
\text { 06AA010 } \\
\text { 06AA011 }\end{array}$ & $\begin{array}{l}\text { SA-516, Gr. } 55 \\
\text { SA-516, Gr. } 60 \\
\text { SA-516, Gr. } 65 \\
\text { SA-516, Gr. } 70\end{array}$ & $\begin{array}{l}\text { A } 516, \text { Gr. } 55 \\
\text { A } 516, \mathrm{Gr} .60 \\
\text { A } 516, \mathrm{Gr} .65 \\
\text { A } 516, \mathrm{Gr} .70\end{array}$ & $\begin{array}{l}\mathrm{MC}, \mathrm{CC} \\
\mathrm{MC}, \mathrm{CC} \\
\mathrm{MC}, \mathrm{CC} \\
\mathrm{MC}, \mathrm{CC}\end{array}$ \\
\hline $\begin{array}{l}\text { 06AA012 } \\
\text { 06AA013 }\end{array}$ & $\begin{array}{l}\text { SA-537, Cl. } 1 \\
\text { SA-537, Cl. } 2\end{array}$ & $\begin{array}{l}\text { A } 537, \mathrm{Cl} .1 \\
\text { A } 537, \mathrm{Cl} .2\end{array}$ & $\begin{array}{l}\mathrm{MC}, \mathrm{CC} \\
\mathrm{MC}, \mathrm{CC}\end{array}$ \\
\hline $\begin{array}{l}\text { 06AA014 } \\
\text { 06AA015 }\end{array}$ & $\begin{array}{l}\text { SA-695, Gr. 35, Type B } \\
\text { SA-695, Gr. 40, Type B }\end{array}$ & $\begin{array}{l}\text { A 695, Gr. 35, Type B } \\
\text { A 695, Gr. 40, Type B }\end{array}$ & $\begin{array}{l}\mathrm{MC} \\
\mathrm{MC}\end{array}$ \\
\hline $\begin{array}{l}\text { 06AA016 } \\
\text { 06AA017 }\end{array}$ & $\begin{array}{l}\text { SA-696, Gr. B } \\
\text { SA-696, Gr. C }\end{array}$ & $\begin{array}{l}\text { A } 696, \text { Gr. B } \\
\text { A } 696, \text { Gr. C }\end{array}$ & $\begin{array}{l}\mathrm{MC} \\
\mathrm{MC}\end{array}$ \\
\hline $\begin{array}{l}\text { 06AA018 } \\
\text { 06AA019 }\end{array}$ & $\begin{array}{l}\text { SA-737, Gr. B } \\
\text { SA-737, Gr. C }\end{array}$ & $\begin{array}{l}\text { A } 737, \text { Gr. B } \\
\text { A } 737, \text { Gr. C }\end{array}$ & $\begin{array}{l}\mathrm{MC} \\
\mathrm{MC}\end{array}$ \\
\hline $\begin{array}{l}\text { 06AA020 } \\
\text { 06AA021 } \\
\text { 06AA022 }\end{array}$ & $\begin{array}{l}\text { SA-738, Gr. A } \\
\text { SA-738, Gr. B } \\
\text { SA-738, Gr. C }\end{array}$ & $\begin{array}{l}\text { A } 738, \text { Gr. A } \\
\text { A } 738, \text { Gr. B } \\
\text { A } 738, \text { Gr. C }\end{array}$ & $\begin{array}{l}\mathrm{MC}, \mathrm{CC} \\
\mathrm{MC}, \mathrm{CC} \\
\mathrm{CC}\end{array}$ \\
\hline
\end{tabular}

Source: 1992 ASME Boiler and Pressure Vessel Code (Refs. 5.2 and 5.3). 
Table 5.3 Carbon and low-alloy steel forgings and castings permitted for use in construction of containment pressure boundary components.

\begin{tabular}{|c|c|c|c|}
\hline $\begin{array}{l}\text { Material } \\
\text { Code }\end{array}$ & $\begin{array}{c}\text { ASME } \\
\text { Material } \\
\text { Specification } \\
\text { Designation }\end{array}$ & $\begin{array}{c}\text { ASTM } \\
\text { Material } \\
\text { Specification } \\
\text { Designation }\end{array}$ & $\begin{array}{c}\text { Metal (MC) } \\
\text { or } \\
\text { Concrete (CC) } \\
\text { Containments }\end{array}$ \\
\hline \multicolumn{4}{|c|}{ Forgings and Castings } \\
\hline $06 \mathrm{AB} 001$ & SA-105 & A 105 & $\mathrm{MC}, \mathrm{CC}$ \\
\hline $\begin{array}{l}06 \mathrm{AB} 002 \\
06 \mathrm{AB} 003\end{array}$ & $\begin{array}{l}\text { SA-181, Cl. } 60 \\
\text { SA-181, Cl. } 70\end{array}$ & $\begin{array}{l}\text { A } 181, \text { Cl. } 60 \\
\text { A } 181, \text { Cl. } 70\end{array}$ & $\begin{array}{l}\mathrm{MC}, \mathrm{CC} \\
\mathrm{MC}, \mathrm{CC}\end{array}$ \\
\hline $\begin{array}{l}06 \mathrm{AB} 004 \\
06 \mathrm{AB} 005 \\
06 \mathrm{AB} 006\end{array}$ & $\begin{array}{l}\text { SA-216, Gr. WCA } \\
\text { SA-216, Gr. WCB } \\
\text { SA-216, Gr. WCC }\end{array}$ & $\begin{array}{l}\text { A } 216, \text { Gr. WCA } \\
\text { A } 216, \text { Gr. WCB } \\
\text { A } 216, \text { Gr. WCC }\end{array}$ & $\begin{array}{l}\mathrm{MC}, \mathrm{CC} \\
\mathrm{MC}, \mathrm{CC} \\
\mathrm{MC}, \mathrm{CC}\end{array}$ \\
\hline $\begin{array}{l}06 \mathrm{AB} 007 \\
06 \mathrm{AB} 008 \\
06 \mathrm{AB} 009\end{array}$ & $\begin{array}{l}\text { SA-266, Cl. } 1 \\
\text { SA-266, Cl. } 2 \\
\text { SA-266, Cl. } 3\end{array}$ & $\begin{array}{l}\text { A } 266, \text { Cl. } 1 \\
\text { A } 266, \text { Cl. } 2 \\
\text { A } 266, \text { Cl. } 3\end{array}$ & $\begin{array}{l}\mathrm{MC}, \mathrm{CC} \\
\mathrm{MC}, \mathrm{CC} \\
\mathrm{CC}\end{array}$ \\
\hline $\begin{array}{l}\text { 06AB010 } \\
06 \mathrm{AB} 011\end{array}$ & $\begin{array}{l}\text { SA-350, Gr. LF1 } \\
\text { SA-350, Gr. LF2 }\end{array}$ & $\begin{array}{l}\text { A } 350, \text { Gr. LF1 } \\
\text { A } 350, \text { Gr. LF2 }\end{array}$ & $\begin{array}{l}\mathrm{MC}, \mathrm{CC} \\
\mathrm{MC}, \mathrm{CC}\end{array}$ \\
\hline $06 \mathrm{AB} 012$ & SA-352, Gr. LCB & A 352 , Gr. LCB & $\mathrm{MC}$ \\
\hline 06AB013 & SA-487, Gr. 16, Cl. A & A 487 , Gr. 16, Cl. A & MC \\
\hline 06АB014 & $\mathrm{SA}-508, \mathrm{Cl} .1$ & A $508, \mathrm{Cl} .1$ & $\mathrm{MC}, \mathrm{CC}$ \\
\hline $06 \mathrm{AB} 015$ & SA-541, Cl. 1 & A $541, \mathrm{Cl} .1$ & $\mathrm{MC}, \mathrm{CC}$ \\
\hline
\end{tabular}

Source: 1992 ASME Boiler and Pressure Vessel Code (Refs. 5.2 and 5.3). 
Table 5.4 Carbon and low-alloy steel pipes, tubes, and fittings permitted for use in construction of containment pressure boundary components.

\begin{tabular}{|c|c|c|c|}
\hline $\begin{array}{l}\text { Material } \\
\text { Code }\end{array}$ & $\begin{array}{c}\text { ASME } \\
\text { Material } \\
\text { Specification } \\
\text { Designation }\end{array}$ & $\begin{array}{c}\text { ASTM } \\
\text { Material } \\
\text { Specification } \\
\text { Designation }\end{array}$ & $\begin{array}{l}\text { Metal (MC) } \\
\text { or } \\
\text { Concrete (CC) } \\
\text { Containments }\end{array}$ \\
\hline \multicolumn{4}{|c|}{ Pipes, Tubes, and Fittings } \\
\hline $\begin{array}{l}\text { 06AC001 } \\
06 \mathrm{AC} 002 \\
06 \mathrm{AC} 003\end{array}$ & $\begin{array}{l}\text { SA-106, Gr. A } \\
\text { SA-106, Gr. B } \\
\text { SA-106, Gr. C }\end{array}$ & $\begin{array}{l}\text { A } 106, \text { Gr. A } \\
\text { A } 106, \text { Gr. B } \\
\text { A } 106, \text { Gr. C }\end{array}$ & $\begin{array}{l}\mathrm{MC}, \mathrm{CC} \\
\mathrm{MC}, \mathrm{CC} \\
\mathrm{MC}, \mathrm{CC}\end{array}$ \\
\hline $\begin{array}{l}\text { 06AC004 } \\
\text { 06AC005 }\end{array}$ & $\begin{array}{l}\text { SA-178, Gr. A } \\
\text { SA-178, Gr. C }\end{array}$ & $\begin{array}{l}\text { A } 178, \text { Gr. A } \\
\text { A } 178, \text { Gr. C }\end{array}$ & $\begin{array}{l}\mathrm{CC} \\
\mathrm{MC}\end{array}$ \\
\hline $\begin{array}{l}\text { 06AC006 } \\
\text { 06AC007 }\end{array}$ & $\begin{array}{l}\text { SA-210, Gr. A-1 } \\
\text { SA-210, Gr. C }\end{array}$ & $\begin{array}{l}\text { A } 210, \text { Gr. A-1 } \\
\text { A } 210, \text { Gr. C }\end{array}$ & $\begin{array}{l}\mathrm{MC}, \mathrm{CC} \\
\mathrm{CC}\end{array}$ \\
\hline $\begin{array}{l}\text { 06AC008 } \\
\text { 06AC009 } \\
\text { 06AC010 } \\
06 \mathrm{AC} 011\end{array}$ & $\begin{array}{l}\text { SA-234, Gr. WPB } \\
\text { SA-234, Gr. WPBW } \\
\text { SA-234, Gr. WPC } \\
\text { SA-234, Gr. WPCW }\end{array}$ & $\begin{array}{l}\text { A } 234, \text { Gr. WPB } \\
\text { A } 234, \text { Gr. WPBW } \\
\text { A } 234, \text { Gr. WPC } \\
\text { A } 234, \text { Gr. WPCW }\end{array}$ & $\begin{array}{l}\mathrm{MC}, \mathrm{CC} \\
\mathrm{MC}, \mathrm{CC} \\
\mathrm{MC}, \mathrm{CC} \\
\mathrm{MC}, \mathrm{CC}\end{array}$ \\
\hline $\begin{array}{l}\text { 06AC012 } \\
06 \mathrm{AC} 013\end{array}$ & $\begin{array}{l}\text { SA-333, Gr. } 1 \\
\text { SA-333, Gr. } 6\end{array}$ & $\begin{array}{l}\text { A } 333, \text { Gr. } 1 \\
\text { A } 333, \text { Gr. } 6\end{array}$ & $\begin{array}{l}\mathrm{MC}, \mathrm{CC} \\
\mathrm{MC}, \mathrm{CC}\end{array}$ \\
\hline $\begin{array}{l}\text { 06AC014 } \\
06 \mathrm{AC} 015\end{array}$ & $\begin{array}{l}\text { SA-334, Gr. } 1 \\
\text { SA-334, Gr. } 6\end{array}$ & $\begin{array}{l}\text { A } 334, \text { Gr. } 1 \\
\text { A } 334, \text { Gr. } 6\end{array}$ & $\begin{array}{l}\mathrm{MC}, \mathrm{CC} \\
\mathrm{MC}, \mathrm{CC}\end{array}$ \\
\hline $\begin{array}{l}\text { 06AC016 } \\
\text { 06AC017 }\end{array}$ & $\begin{array}{l}\text { SA-420, Gr. WPL6 } \\
\text { SA-420, Gr. WPL6W }\end{array}$ & $\begin{array}{l}\text { A } 420 \text {, Gr. WPL6 } \\
\text { A } 420 \text {, Gr. WPLGW }\end{array}$ & $\begin{array}{l}\mathrm{MC}, \mathrm{CC} \\
\mathrm{MC}, \mathrm{CC}\end{array}$ \\
\hline $\begin{array}{l}\text { 06AC018 } \\
\text { 06AC019 } \\
\text { 06AC020 } \\
\text { 06AC021 } \\
\text { 06AC022 } \\
06 \mathrm{ACO} 23 \\
06 \mathrm{AC} 024 \\
06 \mathrm{AC} 025\end{array}$ & $\begin{array}{l}\text { SA-671, Gr. CC60 } \\
\text { SA-671, Gr. CC65 } \\
\text { SA-671, Gr. CC70 } \\
\text { SA-671, Gr. CD70 } \\
\text { SA-671, Gr. CD80 } \\
\text { SA-671, Gr. CE55 } \\
\text { SA-671, Gr. CE60 } \\
\text { SA-671, Gr. CK75 }\end{array}$ & $\begin{array}{l}\text { A } 671, \text { Gr. CC60 } \\
\text { A } 671, \text { Gr. CC65 } \\
\text { A } 671, \text { Gr. CC70 } \\
\text { A } 671, \text { Gr. CD } 70 \\
\text { A } 671, \text { Gr. CD80 } \\
\text { A } 671, \text { Gr. CE55 } \\
\text { A } 671, \text { Gr. CE60 } \\
\text { A } 671, \text { Gr. CK75 }\end{array}$ & $\begin{array}{l}\mathrm{MC} \\
\mathrm{MC} \\
\mathrm{MC} \\
\mathrm{MC} \\
\mathrm{MC} \\
\mathrm{MC} \\
\mathrm{MC} \\
\mathrm{MC}\end{array}$ \\
\hline $\begin{array}{l}06 \mathrm{AC} 026 \\
06 \mathrm{AC} 027 \\
06 \mathrm{AC} 028\end{array}$ & $\begin{array}{l}\text { SA-691, Gr. CMS75 } \\
\text { SA-691, Gr. CMSH70 } \\
\text { SA-691, Gr. CMSH80 }\end{array}$ & $\begin{array}{l}\text { A 691, Gr. CMS75 } \\
\text { A 691, Gr. CMSH70 } \\
\text { A 691, Gr. CMSH80 }\end{array}$ & $\begin{array}{l}\mathrm{MC} \\
\mathrm{MC} \\
\mathrm{MC}\end{array}$ \\
\hline
\end{tabular}

Source: 1992 ASME Boiler and Pressure Vessel Code (Refs. 5.2 and 5.3). 
Table 5.5 Carbon and low-alloy steel bolting materials permitted for use in construction of containment pressure boundary components.

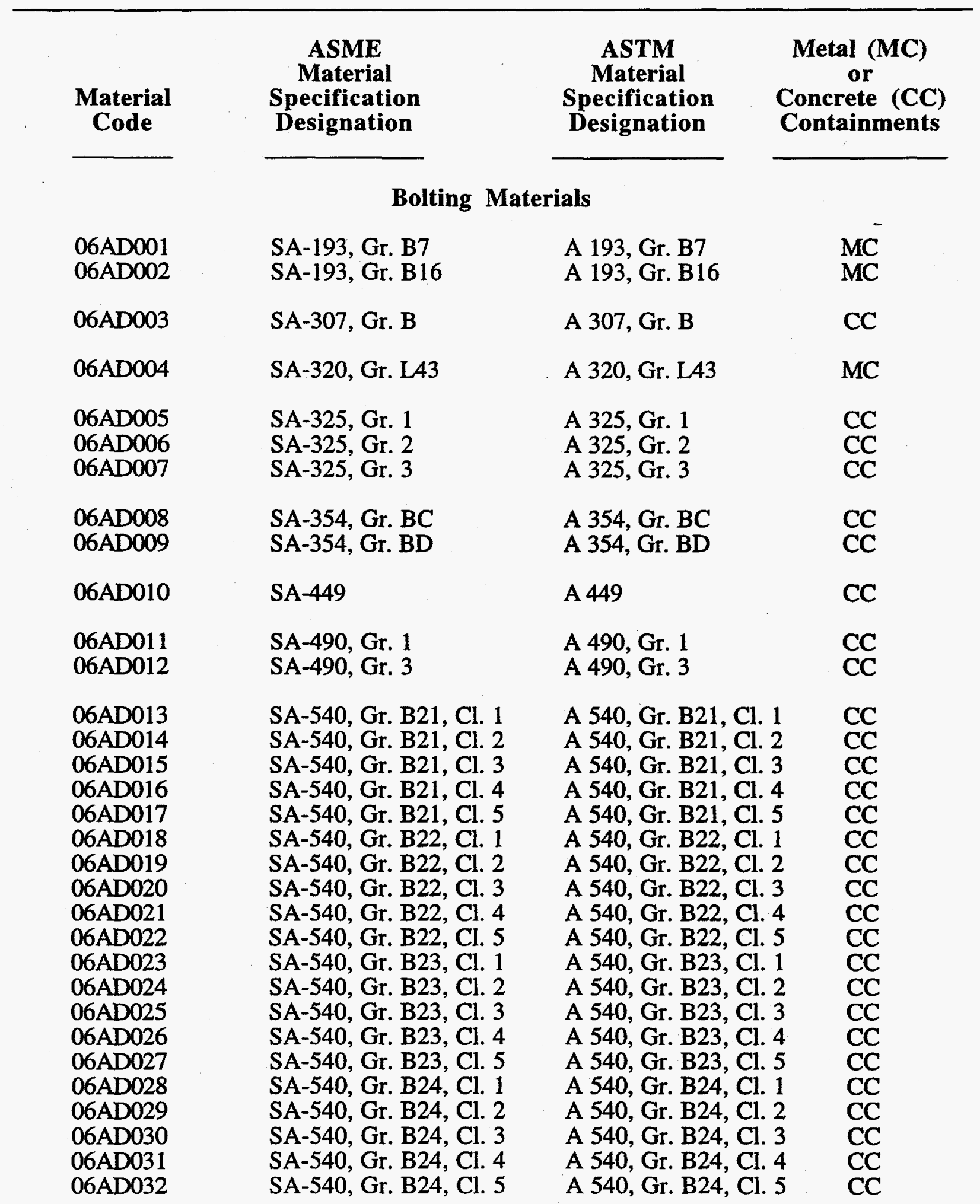


Table 5.5 (cont.) Carbon and low-alloy steel bolting materials permitted for use in construction of containment pressure boundary components.

\begin{tabular}{llll}
\hline $\begin{array}{c}\text { Material } \\
\text { Code }\end{array}$ & $\begin{array}{c}\text { ASME } \\
\text { Material } \\
\text { Specification } \\
\text { Designation }\end{array}$ & $\begin{array}{c}\text { ASTM } \\
\text { Material } \\
\text { Specification } \\
\text { Designation }\end{array}$ & $\begin{array}{c}\text { Metal (MC) } \\
\text { or } \\
\text { Concrete (CC) } \\
\text { Containments }\end{array}$ \\
\cline { 2 - 3 } 06AD033 & BA-563, Gr. O & A 563, Gr. O & CC \\
06AD034 & SA-563, Gr. A & A 563, Gr. A & CC \\
06AD035 & SA-563, Gr. B & A 563, Gr. B & CC \\
06AD036 & SA-563, Gr. C & A 563, Gr. C & CC \\
06AD037 & SA-563, Gr. D & A 563, Gr. D & CC \\
06AD038 & SA-563, Gr. DH & A 563, Gr. DH & CC \\
06AD039 & Not applicable & A 687, Gr. 1 & CC \\
06AD040 & Not applicable & A 687, Gr. 2 & CC \\
06AD041 & Not applicable & F 436 & CC \\
\hline
\end{tabular}

Source: 1992 ASME Boiler and Pressure Vessel Code (Refs. 5.2 and 5.3). 
Table 5.6 Carbon and low-alloy steel special materials permitted for use in construction of containment pressure boundary components.

\begin{tabular}{|c|c|c|c|}
\hline $\begin{array}{c}\text { Material } \\
\text { Code }\end{array}$ & $\begin{array}{c}\text { ASME } \\
\text { Material } \\
\text { Specification } \\
\text { Designation }\end{array}$ & $\begin{array}{c}\text { ASTM } \\
\text { Material } \\
\text { Specification } \\
\text { Designation }\end{array}$ & $\begin{array}{c}\text { Metal (MC) } \\
\text { or } \\
\text { Concrete (CC) } \\
\text { Containments }\end{array}$ \\
\hline \multicolumn{4}{|c|}{ Special Materials } \\
\hline $\begin{array}{l}\text { 06AE001 } \\
\text { 06AE002 } \\
\text { 06AE003 } \\
\text { 06AE004 } \\
\text { 06AE005 }\end{array}$ & $\begin{array}{l}\text { Not applicable } \\
\text { Not applicable } \\
\text { Not applicable } \\
\text { Not applicable } \\
\text { Not applicable }\end{array}$ & $\begin{array}{l}\text { A } 108, \text { Gr. } 1010 \\
\text { A } 108, \text { Gr. } 1015 \\
\text { A } 108, \text { Gr. } 1016 \\
\text { A } 108, \text { Gr. } 1018 \\
\text { A } 108, \text { Gr. } 1020\end{array}$ & $\begin{array}{l}C C \\
C C \\
C C \\
C C \\
C C\end{array}$ \\
\hline $\begin{array}{l}\text { 06AE006 } \\
\text { 06AE007 } \\
\text { 06AE008 } \\
\text { 06AE009 } \\
\text { 06AE010 } \\
\text { 06AE011 } \\
\text { 06AE012 } \\
\text { 06AE013 } \\
\text { 06AE014 } \\
\text { 06AE015 } \\
\text { 06AE016 } \\
\text { 06AE017 } \\
\text { 06AE018 }\end{array}$ & $\begin{array}{l}\text { Not applicable } \\
\text { Not applicable } \\
\text { Not applicable } \\
\text { Not applicable } \\
\text { Not applicable } \\
\text { Not applicable } \\
\text { Not applicable } \\
\text { Not applicable } \\
\text { Not applicable } \\
\text { Not applicable } \\
\text { Not applicable } \\
\text { Not applicable } \\
\text { Not applicable }\end{array}$ & $\begin{array}{l}\text { A 513, Gr. } 1008 \\
\text { A 513, Gr. } 1016 \\
\text { A 513, Gr. } 1017 \\
\text { A 513, Gr. } 1018 \\
\text { A 513, Gr. } 1019 \\
\text { A 513, Gr. } 1021 \\
\text { A 513, Gr. } 1022 \\
\text { A 513, Gr. } 1023 \\
\text { A 513, Gr. } 1024 \\
\text { A 513, Gr. } 1025 \\
\text { A 513, Gr. } 1026 \\
\text { A 513, Gr. } 1027 \\
\text { A 513, Gr. } 1030\end{array}$ & $\begin{array}{l}C C \\
C C \\
C C \\
C C \\
C C \\
C C \\
C C \\
C C \\
C C \\
C C \\
C C \\
C C \\
C C\end{array}$ \\
\hline $\begin{array}{l}\text { 06AE019 } \\
\text { 06AE020 } \\
\text { 06AE021 } \\
\text { 06AE022 } \\
\text { 06AE023 } \\
\text { 06AE024 } \\
\text { 06AE025 } \\
\text { 06AE026 } \\
\text { 06AE027 } \\
\text { 06AE028 } \\
\text { 06AE029 } \\
\text { 06AE030 } \\
\text { 06AE031 } \\
\text { 06AE032 }\end{array}$ & $\begin{array}{l}\text { Not applicable } \\
\text { Not applicable } \\
\text { Not applicable } \\
\text { Not applicable } \\
\text { Not applicable } \\
\text { Not applicable } \\
\text { Not applicable } \\
\text { Not applicable } \\
\text { Not applicable } \\
\text { Not applicable } \\
\text { Not applicable } \\
\text { Not applicable } \\
\text { Not applicable } \\
\text { Not applicable }\end{array}$ & $\begin{array}{l}\text { A } 519, \text { Gr. } 1008 \\
\text { A } 519, \text { Gr. } 1010 \\
\text { A } 519, \text { Gr. } 1012 \\
\text { A } 519, \text { Gr. } 1015 \\
\text { A } 519, \text { Gr. } 1016 \\
\text { A } 519, \text { Gr. } 1017 \\
\text { A } 519, \text { Gr. } 1018 \\
\text { A } 519, \text { Gr. } 1019 \\
\text { A } 519, \text { Gr. } 1020 \\
\text { A } 519, \text { Gr. } 1021 \\
\text { A } 519, \text { Gr. } 1022 \\
\text { A } 519, \text { Gr. } 1025 \\
\text { A } 519, \text { Gr. } 1026 \\
\text { A } 519, \text { Gr. } 1030\end{array}$ & $\begin{array}{l}C C \\
C C \\
C C \\
C C \\
C C \\
C C \\
C C \\
C C \\
C C \\
C C \\
C C \\
C C \\
C C \\
C C\end{array}$ \\
\hline
\end{tabular}


Table 5.7 Stainless steel plates and bars permitted for use in construction of containment pressure boundary components.

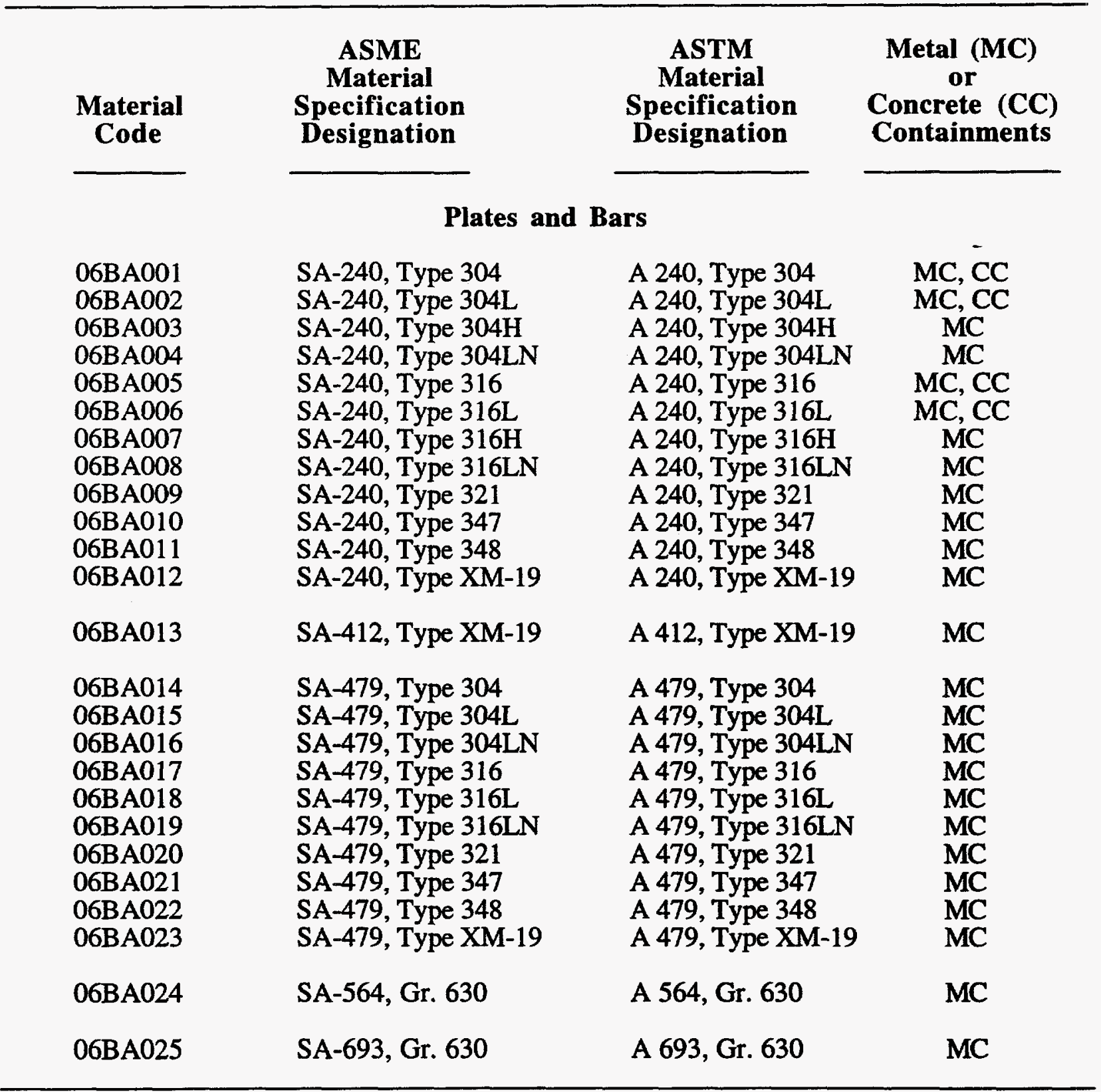


Table 5.8 Stainless steel forgings and castings permitted for use in construction of containment pressure boundary components.

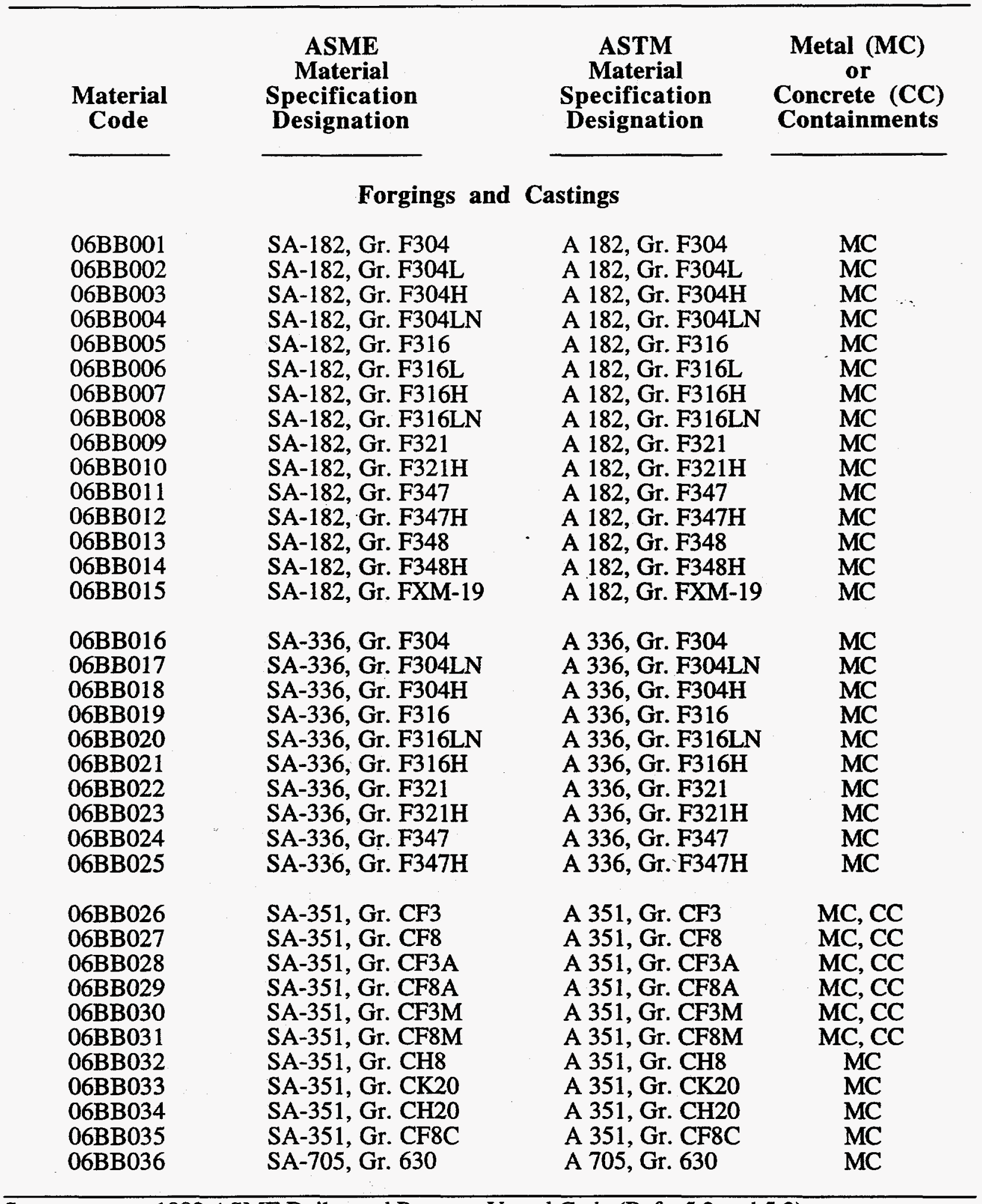

Source: 1992 ASME Boiler and Pressure Vessel Code (Refs. 5.2 and 5.3). 
Table 5.9 Stainless steel pipes, tubes, and fittings permitted for use in construction of containment pressure boundary components.

\begin{tabular}{|c|c|c|c|}
\hline $\begin{array}{l}\text { Material } \\
\text { Code }\end{array}$ & $\begin{array}{c}\text { ASME } \\
\text { Material } \\
\text { Specification } \\
\text { Designation }\end{array}$ & $\begin{array}{c}\text { ASTM } \\
\text { Material } \\
\text { Specification } \\
\text { Designation }\end{array}$ & $\begin{array}{l}\text { Metal (MC) } \\
\text { or } \\
\text { Concrete (C } \\
\text { Containmen }\end{array}$ \\
\hline \multicolumn{4}{|c|}{ Pipes, Tubes, and Fittings } \\
\hline $\begin{array}{l}06 \mathrm{BC} 001 \\
06 \mathrm{BC} 002 \\
06 \mathrm{BC} 003 \\
06 \mathrm{BC} 004 \\
06 \mathrm{BC} 005 \\
06 \mathrm{BC} 006 \\
06 \mathrm{BC} 007 \\
06 \mathrm{BC} 008 \\
06 \mathrm{BC} 009 \\
06 \mathrm{BC} 010 \\
06 \mathrm{BC} 011 \\
06 \mathrm{BC} 012 \\
06 \mathrm{BC} 013 \\
06 \mathrm{BC} 014\end{array}$ & $\begin{array}{l}\text { SA-213, Gr. TP304 } \\
\text { SA-213, Gr. TP304L } \\
\text { SA-213, Gr. TP304H } \\
\text { SA-213, Gr. TP304LN } \\
\text { SA-213, Gr. TP316 } \\
\text { SA-213, Gr. TP316L } \\
\text { SA-213, Gr. TP316H } \\
\text { SA-213, Gr. TP316LN } \\
\text { SA-213, Gr. TP321 } \\
\text { SA-213, Gr. TP321H } \\
\text { SA-213, Gr. TP347 } \\
\text { SA-213, Gr. TP347H } \\
\text { SA-213, Gr. TP348 } \\
\text { SA-213, Gr. TP348H }\end{array}$ & $\begin{array}{l}\text { A 213, Gr. TP304 } \\
\text { A 213, Gr. TP304L } \\
\text { A 213, Gr. TP304H } \\
\text { A 213, Gr. TP304LN } \\
\text { A 213, Gr. TP316 } \\
\text { A 213, Gr. TP316L } \\
\text { A 213, Gr. TP316H } \\
\text { A 213, Gr. TP316LN } \\
\text { A 213, Gr. TP321 } \\
\text { A 213, Gr. TP321H } \\
\text { A 213, Gr. TP347 } \\
\text { A 213, Gr. TP347H } \\
\text { A 213, Gr. TP348 } \\
\text { A 213, Gr. TP348H }\end{array}$ & $\begin{array}{l}M C, C C \\
M C, C C \\
M C \\
M C \\
M C, C C \\
M C, C C \\
M C \\
M C \\
M C \\
M C \\
M C \\
M C \\
M C \\
M C\end{array}$ \\
\hline $\begin{array}{l}06 \mathrm{BC} 015 \\
06 \mathrm{BC} 016 \\
06 \mathrm{BC} 017 \\
06 \mathrm{BC} 018 \\
06 \mathrm{BC} 019 \\
06 \mathrm{BC} 020 \\
06 \mathrm{BC} 021 \\
06 \mathrm{BC} 022 \\
06 \mathrm{BC} 023 \\
06 \mathrm{BC} 024 \\
06 \mathrm{BC} 025 \\
06 \mathrm{BC} 026 \\
06 \mathrm{BC} 027 \\
06 \mathrm{BC} 028 \\
06 \mathrm{BC} 029\end{array}$ & $\begin{array}{l}\text { SA-249, Gr. TP304 } \\
\text { SA-249, Gr. TP304L } \\
\text { SA-249, Gr. TP304H } \\
\text { SA-249, Gr. TP304LN } \\
\text { SA-249, Gr. TP316 } \\
\text { SA-249, Gr. TP316L } \\
\text { SA-249, Gr. TP316H } \\
\text { SA-249, Gr. TP316LN } \\
\text { SA-249, Gr. TP321 } \\
\text { SA-249, Gr. TP321H } \\
\text { SA-249, Gr. TP347 } \\
\text { SA-249, Gr. TP347H } \\
\text { SA-249, Gr. TP348 } \\
\text { SA-249, Gr. TP348H } \\
\text { SA-249, Gr. TPXM-19 }\end{array}$ & $\begin{array}{l}\text { A } 249, \mathrm{Gr} . \text { TP304 } \\
\text { A 249, Gr. TP304L } \\
\text { A 249, Gr. TP304H } \\
\text { A 249, Gr. TP304LN } \\
\text { A 249, Gr. TP316 } \\
\text { A 249, Gr. TP316L } \\
\text { A 249, Gr. TP316H } \\
\text { A 249, Gr. TP316LN } \\
\text { A 249, Gr. TP321 } \\
\text { A 249, Gr. TP321H } \\
\text { A 249, Gr. TP347 } \\
\text { A 249, Gr. TP347H } \\
\text { A 249, Gr. TP348 } \\
\text { A 249, Gr. TP348H } \\
\text { A 249, Gr. TPXM-19 }\end{array}$ & $\begin{array}{l}\text { MC } \\
\text { MC } \\
\text { MC } \\
\text { MC } \\
\text { MC } \\
\text { MC } \\
\text { MC } \\
\text { MC } \\
\text { MC } \\
\text { MC } \\
\text { MC } \\
\text { MC } \\
\text { MC } \\
\text { MC } \\
M C\end{array}$ \\
\hline $\begin{array}{l}06 \mathrm{BC} 030 \\
06 \mathrm{BC} 031 \\
06 \mathrm{BC} 032 \\
06 \mathrm{BC} 033 \\
06 \mathrm{BC} 034 \\
06 \mathrm{BC} 035 \\
06 \mathrm{BC} 036 \\
06 \mathrm{BC} 037\end{array}$ & $\begin{array}{l}\text { SA-312, Gr. TP304 } \\
\text { SA-312, Gr. TP304L } \\
\text { SA-312, Gr. TP304H } \\
\text { SA-312, Gr. TP304LN } \\
\text { SA-312, Gr. TP316 } \\
\text { SA-312, Gr. TP316L } \\
\text { SA-312, Gr. TP316H } \\
\text { SA-312, Gr. TP316LN }\end{array}$ & $\begin{array}{l}\text { A } 312, \mathrm{Gr} . \text { TP304 } \\
\text { A } 312, \mathrm{Gr} . \text { TP304L } \\
\text { A } 312, \mathrm{Gr} \text { TP304H } \\
\text { A } 312, \mathrm{Gr} \text { TP304LN } \\
\text { A } 312, \mathrm{Gr} . \text { TP316 } \\
\text { A } 312, \mathrm{Gr} . \text { TP316L } \\
\text { A } 312, \mathrm{Gr} . \text { TP316H } \\
\text { A } 312, \mathrm{Gr} \text { TP316LN }\end{array}$ & $\begin{array}{l}\mathrm{MC}, \mathrm{CC} \\
\mathrm{MC}, \mathrm{CC} \\
\mathrm{MC} \\
\mathrm{MC} \\
\mathrm{MC} \\
\mathrm{MC} \\
\mathrm{MC} \\
\mathrm{MC}\end{array}$ \\
\hline
\end{tabular}


Table 5.9 (cont.) Stainless steel pipes, tubes, and fittings permitted for use in construction of containment pressure boundary components.

\begin{tabular}{|c|c|c|c|c|}
\hline \multirow[t]{2}{*}{$\begin{array}{l}\text { Material } \\
\text { Code }\end{array}$} & \multicolumn{2}{|r|}{$\begin{array}{c}\text { ASME } \\
\text { Material } \\
\text { Specification } \\
\text { Designation }\end{array}$} & $\begin{array}{c}\text { ASTM } \\
\text { Material } \\
\text { Specification } \\
\text { Designation }\end{array}$ & $\begin{array}{l}\text { Metal (MC } \\
\text { or } \\
\text { Concrete (C } \\
\text { Containmen }\end{array}$ \\
\hline & \multicolumn{4}{|c|}{ Pipes, Tubes, and Fittings (cont.) } \\
\hline $\begin{array}{l}06 \mathrm{BC} 038 \\
06 \mathrm{BC} 039 \\
06 \mathrm{BC} 040 \\
06 \mathrm{BC} 041 \\
06 \mathrm{BC} 042 \\
06 \mathrm{BC} 043 \\
06 \mathrm{BC} 044\end{array}$ & & $\begin{array}{l}\text { SA-312, Gr. TP321 } \\
\text { SA-312, Gr. TP321H } \\
\text { SA-312, Gr. TP347 } \\
\text { SA-312, Gr. TP347H } \\
\text { SA-312, Gr. TP348 } \\
\text { SA-312, Gr. TP348H } \\
\text { SA-312, Gr. TPXM-19 }\end{array}$ & $\begin{array}{l}\text { A } 312, \mathrm{Gr} . \text { TP321 } \\
\text { A } 312, \mathrm{Gr} . \text { TP321H } \\
\text { A } 312, \mathrm{Gr} . \text { TP347 } \\
\text { A } 312, \mathrm{Gr} \text { TP347H } \\
\text { A } 312, \mathrm{Gr} . \text { TP348 } \\
\text { A } 312, \mathrm{Gr} . \text { TP348H } \\
\text { A } 312, \mathrm{Gr} . \text { TPXM-19 }\end{array}$ & $\begin{array}{l}\mathrm{MC} \\
\mathrm{MC} \\
\mathrm{MC} \\
\mathrm{MC} \\
\mathrm{MC} \\
\mathrm{MC} \\
\mathrm{MC}\end{array}$ \\
\hline $\begin{array}{l}06 \mathrm{BC} 045 \\
06 \mathrm{BC} 046 \\
06 \mathrm{BC} 047 \\
06 \mathrm{BC} 048 \\
06 \mathrm{BC} 049 \\
06 \mathrm{BC} 050 \\
06 \mathrm{BC} 051 \\
06 \mathrm{BC} 052 \\
06 \mathrm{BC} 053\end{array}$ & & $\begin{array}{l}\text { SA-358, Gr. 304, Cl. } 1 \\
\text { SA-358, Gr. 304L, Cl. } 1 \\
\text { SA-358, Gr. 304LN, Cl. } 1 \\
\text { SA-358, Gr. 304H, Cl. } 1 \\
\text { SA-358, Gr. 316, Cl. } 1 \\
\text { SA-358, Gr. 316L, Cl. } 1 \\
\text { SA-358, Gr. 316LN, Cl. } 1 \\
\text { SA-358, Gr. 316H, Cl. } 1 \\
\text { SA-358, Gr. XM-19 }\end{array}$ & $\begin{array}{l}\text { A } 358, \mathrm{Gr} .304, \mathrm{Cl} .1 \\
\text { A } 358, \mathrm{Gr} .304 \mathrm{~L}, \mathrm{Cl} .1 \\
\text { A } 358, \mathrm{Gr} .304 \mathrm{LN}, \mathrm{Cl} .1 \\
\text { A } 358, \mathrm{Gr} .304 \mathrm{H}, \mathrm{Cl} .1 \\
\text { A } 358, \mathrm{Gr} .316, \mathrm{Cl} .1 \\
\text { A } 358, \mathrm{Gr} .316 \mathrm{~L}, \mathrm{Cl} .1 \\
\text { A } 358, \mathrm{Gr} .316 \mathrm{LN}, \mathrm{Cl} .1 \\
\text { A } 358, \mathrm{Gr} .316 \mathrm{H}, \mathrm{Cl} .1 \\
\text { A } 358, \mathrm{Gr} . \mathrm{XM}-19\end{array}$ & $\begin{array}{l}\mathrm{MC}, \mathrm{CC} \\
\mathrm{MC}, \mathrm{CC} \\
\mathrm{MC} \\
\mathrm{MC} \\
\mathrm{MC}, \mathrm{CC} \\
\mathrm{MC}, \mathrm{CC} \\
\mathrm{MC} \\
\mathrm{MC} \\
\mathrm{MC}\end{array}$ \\
\hline $\begin{array}{l}06 \mathrm{BC} 054 \\
06 \mathrm{BC} 055 \\
06 \mathrm{BC} 056 \\
06 \mathrm{BC} 057 \\
06 \mathrm{BC} 058 \\
06 \mathrm{BC} 059 \\
06 \mathrm{BC} 060 \\
06 \mathrm{BC} 061 \\
06 \mathrm{BC} 062 \\
06 \mathrm{BC} 063 \\
06 \mathrm{BC} 064\end{array}$ & & $\begin{array}{l}\text { SA-376, Gr. TP304 } \\
\text { SA-376, Gr. TP304H } \\
\text { SA-376, Gr. TP304LN } \\
\text { SA-376, Gr. TP316 } \\
\text { SA-376, Gr. TP316H } \\
\text { SA-376, Gr. TP316LN } \\
\text { SA-376, Gr. TP321 } \\
\text { SA-376, Gr. TP321H } \\
\text { SA-376, Gr. TP347 } \\
\text { SA-376, Gr. TP347H } \\
\text { SA-376, Gr. TP348 }\end{array}$ & $\begin{array}{l}\text { A } 376, \mathrm{Gr} . \text { TP304 } \\
\text { A } 376, \mathrm{Gr} . \text { TP304H } \\
\text { A 376, Gr. TP304LN } \\
\text { A 376, Gr. TP316 } \\
\text { A } 376, \mathrm{Gr} \text { TP316H } \\
\text { A } 376, \mathrm{Gr} \text { TP316LN } \\
\text { A 376, Gr. TP321 } \\
\text { A 376, Gr. TP321H } \\
\text { A 376, Gr. TP347 } \\
\text { A 376, Gr. TP347H } \\
\text { A 376, Gr. TP348 }\end{array}$ & $\begin{array}{l}\text { MC } \\
\text { MC } \\
\text { MC } \\
\text { MC } \\
\text { MC } \\
\text { MC } \\
\text { MC } \\
\text { MC } \\
\text { MC } \\
\text { MC } \\
\text { MC }\end{array}$ \\
\hline $\begin{array}{l}06 \mathrm{BC} 065 \\
06 \mathrm{BC} 066 \\
06 \mathrm{BC} 067 \\
06 \mathrm{BC} 068 \\
06 \mathrm{BC} 069 \\
06 \mathrm{BC} 070 \\
06 \mathrm{BC} 071 \\
06 \mathrm{BC} 072\end{array}$ & & $\begin{array}{l}\text { SA-403, Cl. WP304 } \\
\text { SA-403, Cl. WP304L } \\
\text { SA-403, Cl. WP304LW } \\
\text { SA-403, Cl. WP304H } \\
\text { SA-403, Cl. WP304W } \\
\text { SA-403, Cl. WP304HW } \\
\text { SA-403, Cl. WP304LN } \\
\text { SA-403, Cl. WP304LNW }\end{array}$ & $\begin{array}{l}\text { A 403, Cl. WP304 } \\
\text { A 403, Cl. WP304L } \\
\text { A 403, Cl. WP304LW } \\
\text { A 403, Cl. WP304H } \\
\text { A 403, Cl. WP304W } \\
\text { A 403, Cl. WP304HW } \\
\text { A 403, Cl. WP304LN } \\
\text { A 403, Cl. WP304LNW }\end{array}$ & $\begin{array}{l}\mathrm{MC}, \mathrm{CC} \\
\mathrm{MC}, \mathrm{CC} \\
\mathrm{MC} \\
\mathrm{MC} \\
\mathrm{MC} \\
\mathrm{MC} \\
\mathrm{MC} \\
\mathrm{MC}\end{array}$ \\
\hline
\end{tabular}


Table 5.9 (cont.) Stainless steel pipes, tubes, and fittings permitted for use in construction of containment pressure boundary components.

\begin{tabular}{|c|c|c|c|}
\hline $\begin{array}{c}\text { Material } \\
\text { Code }\end{array}$ & $\begin{array}{c}\text { ASME } \\
\text { Material } \\
\text { Specification } \\
\text { Designation }\end{array}$ & $\begin{array}{c}\text { ASTM } \\
\text { Material } \\
\text { Specification } \\
\text { Designation }\end{array}$ & $\begin{array}{l}\text { Metal (M } \\
\text { or } \\
\text { Concrete } \\
\text { Containm }\end{array}$ \\
\hline \multicolumn{4}{|c|}{ Pipes, Tubes, and Fittings (cont.) } \\
\hline $\begin{array}{l}06 \mathrm{BC} 073 \\
06 \mathrm{BC} 074 \\
06 \mathrm{BC} 075 \\
06 \mathrm{BC} 076 \\
06 \mathrm{BC} 077 \\
06 \mathrm{BC} 078 \\
06 \mathrm{BC} 079 \\
06 \mathrm{BC} 080 \\
06 \mathrm{BC} 081 \\
06 \mathrm{BC} 082 \\
06 \mathrm{BC} 083 \\
06 \mathrm{BC} 084 \\
06 \mathrm{BC} 085 \\
06 \mathrm{BC} 086 \\
06 \mathrm{BC} 087 \\
06 \mathrm{BC} 088 \\
06 \mathrm{BC} 089 \\
06 \mathrm{BC} 090 \\
06 \mathrm{BC} 091 \\
06 \mathrm{BC} 092 \\
06 \mathrm{BC} 093 \\
06 \mathrm{BC} 094\end{array}$ & $\begin{array}{l}\text { SA-403, Cl. WP316 } \\
\text { SA-403, Cl. WP316L } \\
\text { SA-403, Cl. WP316LW } \\
\text { SA-403, Cl. WP316H } \\
\text { SA-403, Cl. WP316W } \\
\text { SA-403, Cl. WP316HW } \\
\text { SA-403, Cl. WP316LN } \\
\text { SA-403, Cl. WP316LNW } \\
\text { SA-403, Cl. WP321 } \\
\text { SA-403, Cl. WP321H } \\
\text { SA-403, Cl. WP321W } \\
\text { SA-403, Cl. WP321HW } \\
\text { SA-403, Cl. WP347 } \\
\text { SA-403, Cl. WP347H } \\
\text { SA-403, Cl. WP347W } \\
\text { SA-403, Cl. WP347HW } \\
\text { SA-403, Cl. WP348 } \\
\text { SA-403, Cl. WP348H } \\
\text { SA-403, Cl. WP348W } \\
\text { SA-403, Cl. WP348HW } \\
\text { SA-403, Cl. WPXM-19 } \\
\text { SA-403, Cl. WPXM-19W }\end{array}$ & 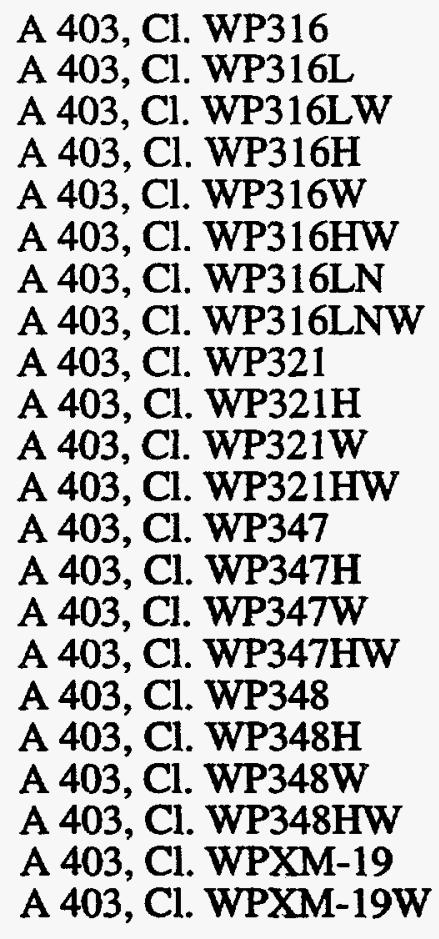 & $\begin{array}{l}\text { MC } \\
M C \\
M C \\
M C \\
M C \\
M C \\
M C \\
M C \\
M C \\
M C \\
M C \\
M C \\
M C \\
M C \\
M C \\
M C \\
M C \\
M C \\
M C \\
M C \\
M C \\
M C\end{array}$ \\
\hline $\begin{array}{l}06 \mathrm{BC} 095 \\
06 \mathrm{BC} 096 \\
06 \mathrm{BC} 097 \\
06 \mathrm{BC} 098 \\
06 \mathrm{BC} 099 \\
06 \mathrm{BC} 100 \\
\text { 06BC101 } \\
\text { 06BC102 }\end{array}$ & $\begin{array}{l}\text { SA-430, Gr. FP304 } \\
\text { SA-430, Gr. FP304H } \\
\text { SA-430, Gr. FP316 } \\
\text { SA-430, Gr. FP316H } \\
\text { SA-430, Gr. FP321 } \\
\text { SA-430, Gr. FP321H } \\
\text { SA-430, Gr. FP347 } \\
\text { SA-430, Gr. FP347H }\end{array}$ & $\begin{array}{l}\text { A } 430, \text { Gr. FP304 } \\
\text { A 430, Gr. FP304H } \\
\text { A 430, Gr. FP316 } \\
\text { A 430, Gr. FP316H } \\
\text { A 430, Gr. FP321 } \\
\text { A 430, Gr. FP321H } \\
\text { A 430, Gr. FP347 } \\
\text { A 430, Gr. FP347H }\end{array}$ & $\begin{array}{r}\mathrm{MC}, \mathrm{C} \\
\mathrm{MC}, \mathrm{C} \\
\mathrm{MC}, \mathrm{C} \\
\mathrm{MC} \\
\mathrm{MC} \\
\mathrm{MC} \\
\mathrm{MC}\end{array}$ \\
\hline $\begin{array}{l}06 \mathrm{BC} 103 \\
06 \mathrm{BC} 104 \\
06 \mathrm{BC} 105\end{array}$ & $\begin{array}{l}\text { SA-452, Gr. TP304H } \\
\text { SA-452, Gr. TP316H } \\
\text { SA-452, Gr. TP347H }\end{array}$ & $\begin{array}{l}\text { A } 452, \text { Gr. TP304H } \\
\text { A 452, Gr. TP316H } \\
\text { A 452, Gr. TP347H }\end{array}$ & $\begin{array}{l}\mathrm{MC} \\
\mathrm{MC} \\
\mathrm{MC}\end{array}$ \\
\hline
\end{tabular}


Table 5.9 (cont.) Stainless steel pipes, tubes, and fittings permitted for use in construction of containment pressure boundary components.

\begin{tabular}{|c|c|c|c|}
\hline $\begin{array}{c}\text { Material } \\
\text { Code }\end{array}$ & $\begin{array}{c}\text { ASME } \\
\text { Material } \\
\text { Specification } \\
\text { Designation }\end{array}$ & $\begin{array}{c}\text { ASTM } \\
\text { Material } \\
\text { Specification } \\
\text { Designation }\end{array}$ & $\begin{array}{l}\text { Metal (MC) } \\
\text { or } \\
\text { Concrete (CC) } \\
\text { Containments }\end{array}$ \\
\hline \multicolumn{4}{|c|}{ Pipes, Tubes, and Fittings (cont.) } \\
\hline $\begin{array}{l}06 \mathrm{BC} 106 \\
06 \mathrm{BC} 107 \\
06 \mathrm{BC} 108 \\
06 \mathrm{BC} 109 \\
06 \mathrm{BC} 110 \\
06 \mathrm{BC} 111 \\
06 \mathrm{BC} 112 \\
06 \mathrm{BC} 113 \\
06 \mathrm{BC} 114 \\
06 \mathrm{BC} 115 \\
06 \mathrm{BC} 116 \\
06 \mathrm{BC} 117 \\
06 \mathrm{BC} 118 \\
06 \mathrm{BC} 119 \\
06 \mathrm{BC} 120 \\
06 \mathrm{BC} 121\end{array}$ & $\begin{array}{l}\text { SA-813, Gr. TP304 } \\
\text { SA-813, Gr. TP304L } \\
\text { SA-813, Gr. TP304H } \\
\text { SA-813, Gr. TP304LN } \\
\text { SA-813, Gr. TP304N } \\
\text { SA-813, Gr. TP316 } \\
\text { SA-813, Gr. TP316L } \\
\text { SA-813, Gr. TP316H } \\
\text { SA-813, Gr. TP316LN } \\
\text { SA-813, Gr. TP321 } \\
\text { SA-813, Gr. TP321H } \\
\text { SA-813, Gr. TP347 } \\
\text { SA-813, Gr. TP347H } \\
\text { SA-813, Gr. TP348 } \\
\text { SA-813, Gr. TP348H } \\
\text { SA-813, Gr. TPXM-19 }\end{array}$ & $\begin{array}{l}\text { A 813, Gr. TP304 } \\
\text { A 813, Gr. TP304L } \\
\text { A 813, Gr. TP304H } \\
\text { A 813, Gr. TP304LN } \\
\text { A 813, Gr. TP304N } \\
\text { A 813, Gr. TP316 } \\
\text { A 813, Gr. TP316L } \\
\text { A 813, Gr. TP316H } \\
\text { A 813, Gr. TP316LN } \\
\text { A 813, Gr. TP321 } \\
\text { A 813, Gr. TP321H } \\
\text { A 813, Gr. TP347 } \\
\text { A 813, Gr. TP347H } \\
\text { A 813, Gr. TP348 } \\
\text { A 813, Gr. TP348H } \\
\text { A 813, Gr. TPXM-19 }\end{array}$ & $\begin{array}{l}\text { MC } \\
\text { MC } \\
\text { MC } \\
\text { MC } \\
\text { MC } \\
\text { MC } \\
\text { MC } \\
\text { MC } \\
\text { MC } \\
\text { MC } \\
\text { MC } \\
\text { MC } \\
\text { MC } \\
\text { MC } \\
M C \\
M C\end{array}$ \\
\hline $\begin{array}{l}06 \mathrm{BC} 122 \\
06 \mathrm{BC} 123 \\
06 \mathrm{BC} 124 \\
06 \mathrm{BC} 125 \\
06 \mathrm{BC} 126 \\
06 \mathrm{BC} 127 \\
06 \mathrm{BC} 128 \\
06 \mathrm{BC} 129 \\
06 \mathrm{BC} 130 \\
06 \mathrm{BC} 131 \\
06 \mathrm{BC} 132 \\
06 \mathrm{BC} 133 \\
06 \mathrm{BC} 134 \\
06 \mathrm{BC} 135 \\
06 \mathrm{BC} 136 \\
06 \mathrm{BC} 137\end{array}$ & $\begin{array}{l}\text { SA-814, Gr. TP304 } \\
\text { SA-814, Gr. TP304L } \\
\text { SA-814, Gr. TP304H } \\
\text { SA-814, Gr. TP304LN } \\
\text { SA-814, Gr. TP316 } \\
\text { SA-814, Gr. TP316L } \\
\text { SA-814, Gr. TP316H } \\
\text { SA-814, Gr. TP316LN } \\
\text { SA-814, Gr. TP316N } \\
\text { SA-814, Gr. TP321 } \\
\text { SA-814, Gr. TP321H } \\
\text { SA-814, Gr. TP347 } \\
\text { SA-814, Gr. TP347H } \\
\text { SA-814, Gr. TP348 } \\
\text { SA-814, Gr. TP348H } \\
\text { SA-814, Gr. TPXM-19 }\end{array}$ & $\begin{array}{l}\text { A 814, Gr. TP304 } \\
\text { A 814, Gr. TP304L } \\
\text { A 814, Gr. TP304H } \\
\text { A 814, Gr. TP304LN } \\
\text { A 814, Gr. TP316 } \\
\text { A 814, Gr. TP316L } \\
\text { A 814, Gr. TP316H } \\
\text { A 814, Gr. TP316LN } \\
\text { A 814, Gr. TP316N } \\
\text { A 814, Gr. TP321 } \\
\text { A 814, Gr. TP321H } \\
\text { A 814, Gr. TP347 } \\
\text { A 814, Gr. TP347H } \\
\text { A 814, Gr. TP348 } \\
\text { A 814, Gr. TP348H } \\
\text { A 814, Gr. TPXM-19 }\end{array}$ & $\begin{array}{l}\text { MC } \\
\text { MC } \\
\text { MC } \\
\text { MC } \\
\text { MC } \\
\text { MC } \\
\text { MC } \\
\text { MC } \\
\text { MC } \\
\text { MC } \\
\text { MC } \\
\text { MC } \\
\text { MC } \\
\text { MC } \\
\text { MC } \\
M C\end{array}$ \\
\hline
\end{tabular}

Source: 1992 ASME Boiler and Pressure Vessel Code (Refs. 5.2 and 5.3). 
Table 5.10 Stainless steel bolting materials permitted for use in construction of containment pressure boundary components.

\begin{tabular}{|c|c|c|c|}
\hline $\begin{array}{c}\text { Material } \\
\text { Code }\end{array}$ & $\begin{array}{c}\text { ASME } \\
\text { Material } \\
\text { Specification } \\
\text { Designation }\end{array}$ & $\begin{array}{c}\text { ASTM } \\
\text { Material } \\
\text { Specification } \\
\text { Designation }\end{array}$ & $\begin{array}{l}\text { Metal (MC) } \\
\text { or } \\
\text { Concrete (CC) } \\
\text { Containments }\end{array}$ \\
\hline \multicolumn{4}{|c|}{ Bolting Materials } \\
\hline $\begin{array}{l}\text { 06BD001 } \\
06 \mathrm{BD} 002 \\
06 \mathrm{BD} 003 \\
\text { 06BD004 } \\
\text { 06BD005 }\end{array}$ & $\begin{array}{l}\text { SA-193, Gr. B6, Cl. } 410 \\
\text { SA-193, Gr. B8 } \\
\text { SA-193, Gr. B8C } \\
\text { SA-193, Gr. B8T } \\
\text { SA-193, Gr. B8M }\end{array}$ & $\begin{array}{l}\text { A } 193, \mathrm{Gr} . \mathrm{B} 6, \mathrm{Cl} .410 \\
\text { A } 193, \mathrm{Gr} . \mathrm{B} 8 \\
\text { A } 193, \mathrm{Gr} . \mathrm{B} 8 \mathrm{C} \\
\text { A } 193, \mathrm{Gr} . \mathrm{B} 8 \mathrm{~T} \\
\text { A } 193, \mathrm{Gr} . \mathrm{B} 8 \mathrm{M}\end{array}$ & $\begin{array}{l}\mathrm{MC} \\
\mathrm{MC} \\
\mathrm{MC} \\
\mathrm{MC} \\
\mathrm{MC}\end{array}$ \\
\hline $\begin{array}{l}\text { 06BD007 } \\
\text { 06BD008 }\end{array}$ & $\begin{array}{l}\text { SA-437, Gr. B4B } \\
\text { SA-437, Gr. B4C }\end{array}$ & $\begin{array}{l}\text { A } 437, \text { Gr. B4B } \\
\text { A } 437, \text { Gr. B4C }\end{array}$ & $\begin{array}{l}\mathrm{MC} \\
\mathrm{MC}\end{array}$ \\
\hline $\begin{array}{l}\text { 06BD009 } \\
\text { 06BD010 }\end{array}$ & $\begin{array}{l}\text { SA-453, Gr. } 651 \\
\text { SA-453, Gr. } 610\end{array}$ & $\begin{array}{l}\text { A } 453, \text { Gr. } 651 \\
\text { A } 453, \text { Gr. } 610\end{array}$ & $\begin{array}{l}\text { MC } \\
\text { MC }\end{array}$ \\
\hline
\end{tabular}

Source: 1992 ASME Boiler and Pressure Vessel Code (Refs. 5.2 and 5.3). 


\section{SUMMARY}

\subsection{STEELS PERMITTED FOR CONTAINMENT CONSTRUCTION}

Section III of the ASME Boiler and Pressure Vessel Code (Refs. 6.1 and 6.2) addresses almost every aspect of metal and concrete containment design. The Code lists material specifications for carbon, low-alloy, and high-alloy steels permitted for use in construction of containment pressure boundary components (Ref 6.3), provides temperature-dependent material properties and design values for each steel (Ref. 6.4), includes rules for calculating the required minimum thickness of pressure retaining components, and recognizes that service-related degradation to pressure retaining components is possible. Material specifications permitted for use in construction of containment pressure boundary components are listed in Tables 2.1 to 2.4.

Missing from the Code are rules for material selection and in-service degradation. These topics are outside its scope. It is the Owner's responsibility to select materials that are suitable for the service conditions and to increase the minimum required thickness of the base metal to offset material thinning due to corrosion, erosion, mechanical abrasion, or other environmental effects.

\subsection{CONTAINMENT STEEL DEGRADATION}

Structural capacity and leaktight integrity of metal and concrete containments can be jeopardized by degradation of pressure boundary components. Potential degradation mechanisms include fatigue, corrosion, neutron irradiation, and extreme temperature exposure. These mechanisms can adversely affect structural performance by changing the geometry of a pressure retaining component or by influencing its material properties. A list of degradation mechanisms that could potentially affect the structural integrity of containment steels is presented in Table 6.1. Beside each degradation mechanism is an assessment of its significance on containment integrity and its potential effect on containment steels. Based on these assessments, metallurgically influenced corrosion (intergranular and dealloying corrosion), stress-corrosion cracking (SCC), and elevatedtemperature exposure are the degradation mechanisms most likely to influence containment steel properties.

\subsection{PROPOSED ACTIVITIES}

Containment steel data and information will be collected at the Structural Materials Information Center and presented in two complementary formats. The Structural Materials Handbook is an expandable, hard-copy reference document that contains the complete data base for each material. The Structural Materials Electronic Data Base is accessible using an IBM-compatible personal computer and provides an efficient means for searching the various data base files to locate materials with common properties and similar characteristics. Candidate steels that could be included in the data base are listed in Tables 5.2 to 5.10. Each steel has been assigned a sevencharacter material code that will be used in the handbook and the electronic data base as a unique material identifier. Properties for each steel will be identified using four-digit property codes and reported using the International System of Units (SI) and in customary units whenever possible.

Research at the Structural Materials Information Center will initially focus on collecting data and information for containment steels listed in Table 5.1. Search efforts will concentrate on identifying reports and references that quantify the effects of metallurgically influenced corrosion, SCC, and elevated temperature exposure on the properties of containment steels. Requirements presented in Table 1.1 will be used to identify materials that are suitable for entry into the data base. As a minimum, general information must be reported for each steel so that unique material 
identification can be established, and experimental results, test data, or nominal property values must be available. Mechanical and physical property values provided in Section II, Part D of the Code (Ref. 6.4) will be used to supplement data and information that are collected. After data and information are collected, handbook pages and electronic data base files will be developed.

\subsection{REFERENCES}

6.1 "Rules for Construction of Nuclear Power Plant Components," ASME Boiler and Pressure Vessel Code, Section III, Division 1 - Subsection NE, Class MC Components, American Society of Mechanical Engineers, New York, New York, July 1, 1992.

6.2 "Rules for Construction of Nuclear Power Plant Components," ASME Boiler and Pressure Vessel Code, Section III, Division 2, Code for Concrete Reactor Vessels and Containments, Subsection CC, Concrete Containments (Prestressed or Reinforced), American Society of Mechanical Engineers, New York, New York, July 1, 1992.

6.3 "Materials," ASME Boiler and Pressure Vessel Code, Section II, Part A - Ferrous Materials Specifications, American Society of Mechanical Engineers, New York, New York, July 1, 1992.

6.4 "Materials," ASME Boiler and Pressure Vessel Code, Section II, Part D - Properties, American Society of Mechanical Engineers, New York, New York, July 1, 1992.

6.5 Shah, V. N., Smith, S. K., and Sinha, U. P., "Insights for Aging Management of Light Water Reactor Components - Metal Containments," NUREG/CR-5314, EGG-2562, Vol. 5, Idaho National Engineering Laboratory, EG\&G Idaho, Inc., Idaho Falls, Idaho, March 1994. 
Table 6.1 Degradation mechanisms that could potentially affect containment steels.

\section{DEGRADATION MECHANISM}

Fatigue

General and Localized Corrosion

Metallurgically Influenced Corrosion

Mechanically Assisted Degradation

\section{POTENTIAL EFFECT ON CONTAINMENT STEELS}

Corrosion-assisted fatigue, thermal ratchet, and lowcycle fatigue are not expected to be a generic concern for either metal or concrete containments (Ref. 6.5). When fatigue is a design issue, the ASME Boiler and Pressure Vessel Code provides rules for fatigue assessments.

General and localized corrosion of pressure boundary components can cause uniform thinning and pitting resulting in significant loss of section or fullthickness penetration. Properties of containment steels are not significantly affected by the various forms of general and localized corrosion.

Intergranular corrosion takes place when the corrosion rate of the grain-boundary areas of an alloy exceed that of the grain interiors. Differences in composition between the grain boundaries and the interior cause differences in the corrosion rates. As the grain boundaries dissolve, the unaffected grains are undermined and fall out. Consequently, metals that experience intergranular corrosion exhibit timedependent weight loss performance that can accelerate with time. Dealloying is a corrosion process in which one constituent of an alloy is preferentially removed leaving behind an altered residual structure. The metal in the affected area becomes porous and loses much of its strength, hardness, and ductility. Because metallurgically influenced corrosion of steel alters its chemical composition and changes its microstructure, it can affect the properties of the metal. A search for data and information pertaining to metallurgically influenced corrosion on containment steels will be conducted at the Structural Materials Information Center.

Degradation of containment pressure boundary components due to forms of mechanically assisted degradation including erosion corrosion, fretting corrosion, fatigue corrosion, cavitation, and water drop impingement is not expected. 
Table 6.1 (cont.) Degradation mechanisms that could potentially affect containment steels.

DEGRADATION

MECHANISM

Environmentally Induced Cracking

Neutron Irradiation

Low-Temperature Exposure

High-Temperature Exposure

\section{POTENTIAL EFFECT ON CONTAINMENT STEELS}

Environmentally induced cracking such as hydrogen damage (embrittlement) and stress-corrosion cracking (SCC) are two forms of corrosion-related degradation that can alter the microstructure of certain steels and thereby influence their mechanical properties. A search for data and information pertaining to SSC of containment steels will be conducted at the Structural Materials Information Center.

Neutron irradiation of containment steels is not expected to be significant because end-of-life fluence is anticipated to be quite small (Ref. 6.5).

Brittle fracture of pressure boundary components caused by exposure to low temperatures is not likely to occur because containment steels normally operate at somewhat above ambient conditions.

In certain situations, containment steel temperatures can be high enough to influence material properties. For this reason, design rules for pressure retaining components exposed to elevated temperatures and temperature-dependent material property values are provided in the ASME Boiler and Pressure Vessel Code. Temperature-dependent data and information for containment steels will be collected at the Structural Materials Information Center and included in the handbook and the electronic data base. 
APPENDIX

EXAMPLE STRUCTURAL MATERIALS HANDBOOK PAGES

FOR ASME SA-36 CONTAINMENT STEEL 


\section{STRUCTURAL MATERIALS HANDBOOK Volume 1 - Performance Values Chapter 6 - Containment Steels}


STRUCTURAL MATERIALS HANDBOOK

Volume 1 - Performance Values

Material Code 06AA001

Property Code 3711

Page 1.1

Containment steel

Carbon steel.

Hot-Rolled steel

Tensile Yield Strength

vs Temperature

Update Package Number 5

Revision control code 0.0

Quality Level B

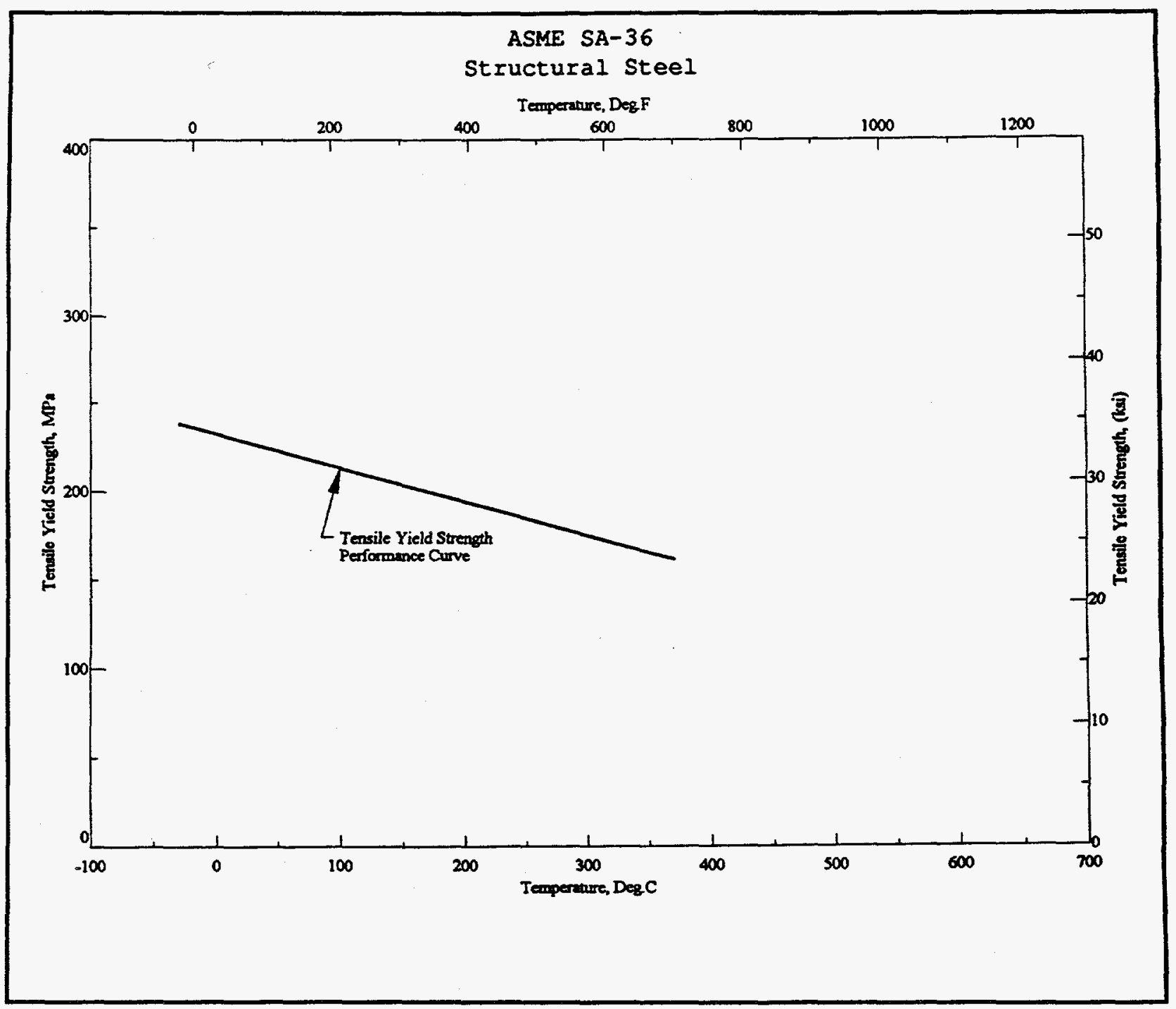

\begin{tabular}{|l|l|}
\hline $\begin{array}{l}\text { Preparer: C. B. Oland } \\
\text { Organization: } \\
\text { Oak Ridge National } \\
\text { Laboratory }\end{array}$ & $\begin{array}{l}\text { Sources: References 18, 97, 100, and } \\
103 .\end{array}$ \\
\hline $\begin{array}{l}\text { See Page } 1.2 \text { for a list of computed temperature-dependent tensile yield } \\
\text { strength values and the equations used to generate this tensile yield } \\
\text { strength performance curve. }\end{array}$
\end{tabular}


Tensile Yield Strength vs Temperature
Opdate Package Number 5 Revision Control Code 0.0 Quality Level $B$

Table of Computed Tensile Yield Strength Values

\begin{tabular}{|c|c|c|}
\hline $\begin{array}{c}\text { Temperature, } \\
{ }^{\circ} \mathrm{C}\left({ }^{\circ} \mathrm{F}\right)\end{array}$ & $\begin{array}{c}\text { Tensile Yield Strength, } \\
\text { MPa }\end{array}$ & $\begin{array}{c}\text { Tensile Yield Strength, } \\
\text { ksi }\end{array}$ \\
\hline$-29(-20)$ & 239 & 34.6 \\
$38(100)$ & 226 & 32.7 \\
$93(200)$ & 215 & 31.2 \\
$149(300)$ & 205 & 29.7 \\
$204(400)$ & 194 & 28.1 \\
$260(500)$ & 183 & 26.6 \\
$316(600)$ & 173 & 25.0 \\
$371(700)$ & 162 & 23.5 \\
\hline
\end{tabular}

The tensile yield strength performance curve shown on Page 1.1 reflects the tensile yield strength values provided in section II, Part D of the ASME Boiler and Pressure vessel code (Reference 103) for containment steel conforming to ASME SA-36/SA-36M requirements (Reference 97). The tensile $y$ ield strength values listed above, and the tensile yield strength performance curve were calculated from the following equations:

$\mathrm{Fy}=233-0.191$ (T) MPa $\quad$ for $-29^{\circ} \mathrm{C} \leq \mathrm{T} \leq 371^{\circ} \mathrm{C}$

Where Fy is the tensile yield strength, and $T$ is the temperature in degrees Celsius.

or

$f_{y}=34.3-0.0154$ (t) $\mathrm{ksi} \quad$ for $-20^{\circ} \mathrm{F} \leq t \leq 700^{\circ} \mathrm{F}$

Where fy is the tensile yield strength, and $t$ is the temperature in degrees Fahrenheit. 
Ultimate Tensile

Strength

vs Temperature
Update Package Number 5

Revision Control code 0.0 Quality Level B

ASME SA-36

Structural steel

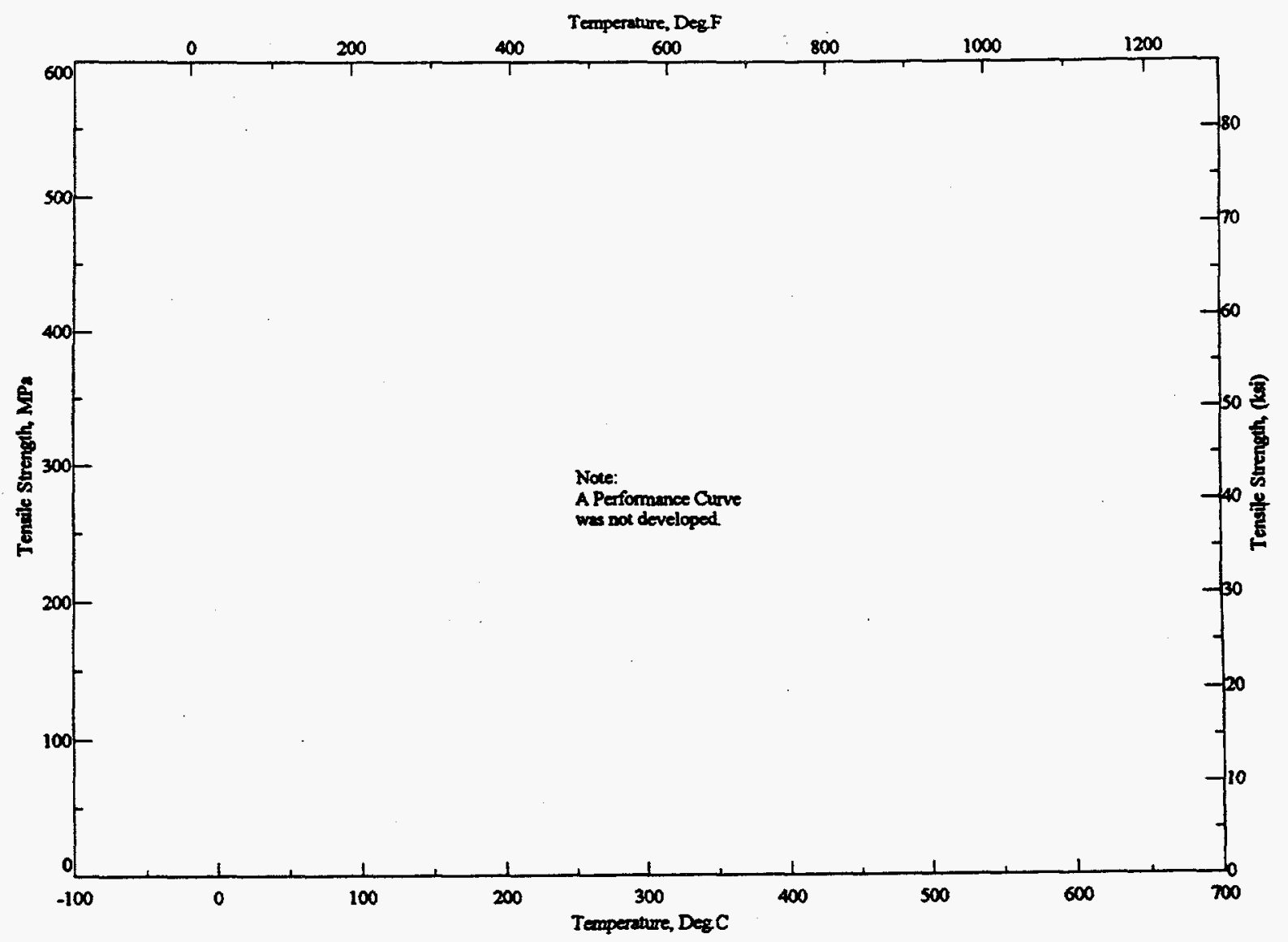

Preparer: C. B. Oland

Sources: References 18, 97, 100, and Organization: Oak Ridge National 103.

Laboratory

The reason the temperature-dependent tensile strength performance curve was not developed is explained on Page 2.2 . 
Containment steel Carbon steel

Hot-Rolled steel

ASME SA-36
Ultimate Tensile Strength vs Temperature
Opdate Package Number 5 Revision Control Code 0.0 Quality Level B

\footnotetext{
A table of computed tensile strength values and equations used to generate the tensile strength performance curve for containment steel conforming to ASME SA-36/SA-36M, requirements (Reference 97) were not developed because tensile strength values for this steel are not provided in section II, Part $D$ of the ASME Boiler and Pressure Vessel Code (Reference 103). Tensile strength values for this steel were also not provided in Section III, Division 1 - Appendices of the 1989 edition of the code. Reasons for the omissions were not presented.
} 
Update Package Number 5 Revision Control code 0.0 Quality Level B

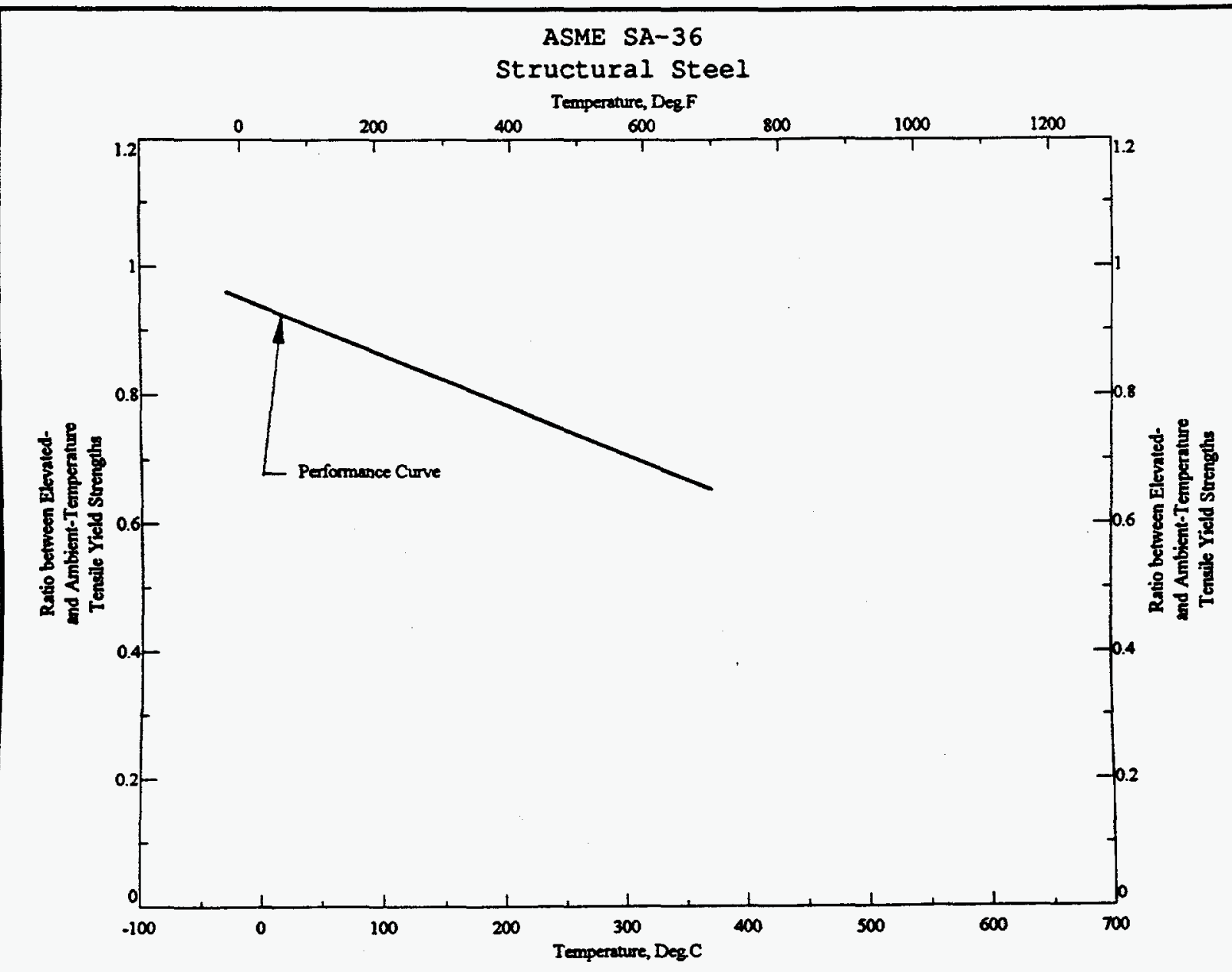

Preparer:

C. B. Oland

Sources: References 17, 18, 22, 97, Organization: Oak Ridge National 100 , and 103 .

Laboratory

See Page 3.2 for a list of computed elevated- to ambient-temperature tensile yield strength ratios and the equations used to generate this performance curve. 
STRUCTURAL MATERIALS HANDBOOK

Volume 1 - Performance Values

Material Code 06AAO01

Property Code 3713

Page 3.2

Containment steel

Carbon steel

Hot-Rolled steel

ASME SA-36

Tensile Yield Strength

Ratio vs Temperature
Update Package Number 5 Revision Control Code 0.0 Quality Level B

Table of Computed Tensile Yield Strength Related Values

\begin{tabular}{|c|c|c|}
\hline $\begin{array}{c}\text { Temperature, } \\
{ }^{\circ} \mathrm{C}\left({ }^{\circ} \mathrm{F}\right)\end{array}$ & $\begin{array}{c}\text { Ratio between Elevated- and } \\
\text { Ambient-Temperature } \\
\text { Tensile Yield Strengths }\end{array}$ & $\begin{array}{c}\text { Tensile Yield Strength } \\
\text { Based on a M1nimum Yield } \\
\text { Strength of 248 MPa (36 ksi), } \\
\text { MPa (ksi) }\end{array}$ \\
\hline$-29(-20)$ & 0.96 & $239(34.6)$ \\
$38(100)$ & 0.91 & $225(32.8)$ \\
$93(200)$ & 0.87 & $215(31.2)$ \\
$149(300)$ & 0.83 & $204(29.7)$ \\
$204(400)$ & 0.78 & $194(28.2)$ \\
$260(500)$ & 0.74 & $183(26.6)$ \\
$316(600)$ & 0.70 & $173(25.1)$ \\
$371(700)$ & 0.65 & $163(23.6)$ \\
\hline
\end{tabular}

The performance curve shown on Page 1.1 reflects the relationship between elevated- and ambient-temperature tensile yield strengths for containment steel conforming to ASME SA-36/SA-36M requirements (Reference 97). The tensile yield strength values listed above, and the performance curve were calculated from the following equations:

$R=0.939-7.660 \times 10^{-4}(T)$

for $-29^{\circ} \mathrm{C} \leq \mathrm{T} \leq 371^{\circ} \mathrm{C}$

Where $R$ is the ratio between elevated- and ambient-temperature tensile yield strengths, and $T$ is the temperature in degrees Celsius.

or

$r=0.953-4.260 \times 10^{-4}(t)$

for $-20^{\circ} \mathrm{F} \leq t \leq 700^{\circ} \mathrm{F}$

Where $r$ is the ratio between elevated- and ambient-temperature tensile yield strengths, and $t$ is the temperature in degrees Fahrenhelt. 


\section{STRUCTURAL MATERIALS HANDBOOK Volume 2 - Supporting Documentation Chapter 6 - Containment Steels}


Tensile Yield Strength

vs Temperature
Update Package Number 5 Revision Control code 0.0 Quality Level B

Preparer: C. B. Oland

Organization: Oak Ridge National Laboratory

Sources: References 18, 97, 100, and 103

\section{Information Sources}

Reference 18: ASTM STP 464. This information source contains mechanical properties at elevated temperatures for three metallic materials including ASTM A 36 structural steel.

Reference 97: ASME Material Specification SA-36/SA-36M. This material specification contains chemical and strength requirements for a carbonmanganese-silicon steel intended for use in construction of buildings and bridges and in containment pressure vessel applications. This specification is identical to ASTM A $36 / \mathrm{A} 36 \mathrm{M}$ (Reference 100).

Reference 100: ASTM Material Specification A 36/A 36M. This material specification contains chemical and strength requirements for a carbonmanganese-silicon steel intended for use in construction of buildings and bridges and in containment pressure vessel applications. This specification is identical to ASME SA-36/SA-36M (Reference 97).

Reference 103: ASME Boiler and Pressure Vessel Code - Section II, Part D. This information source contains temperature-dependent material properties for steels permitted for use in construction of containment pressure boundary components. 
STRUCTURAL MATERIALS HANDBOOK

Volume 2 - Supporting Documentation

Material Code 06AA001

Property Code 3711

Page 1.2

Containment steel

Carbon steel

Hot-Rolled Steel

ASME SA-36

Tensile Yield Strength vs Temperature
Update Package Number 5

Revision Control code 0.0 Quality Level B

"Selected Property" - Evaluation for Quality Level B

Requirement 1 - Completeness of Material Description

The material conforms to ASME SA-36/SA-36M and ASTM A 36/A 36M requirements.

These material specifications are identical.

Requirement 2 - Stability of the Material

The material is stable at temperatures up to $649^{\circ} \mathrm{C}\left(1,200^{\circ} \mathrm{F}\right)$.

Requirement 3 - Type of Input from the References and Sources

Temperature-dependent tensile yield strength values are reported.

Requirement 4 - Completeness of Data and Values Search

Values for $12.7-\mathrm{mm}(0.5-\mathrm{in})$ thick steel plates are reported in Reference 18 .

Requirement 5 - Completeness of Resources

Values at temperatures ranging from -29 to $649^{\circ} \mathrm{C}\left(-20\right.$ to $\left.1,200^{\circ} \mathrm{F}\right)$ are reported.

Requirement 6 - Quality of the References or Sources

The values reported in Reference 103 were developed specifically for steel conforming to ASME SA-36/SA-36M requirements. However, references containing the data and test results used to establish these values were not identified.

Requirement 7 - Availability of Data and Values

Values at 12 temperatures are provided in Reference 18.

Requirement 8 - Consistency of the Data and Values with Respect to Related Properties

Reported yield strength values are consistent with other sets of yield strength values reported for other steels with similar compositions.

Requirement 9 - Precision or Scatter of the Data or Values

Reported values are typical for this type of low-carbon steel with a minimum specified yield strength of $448 \mathrm{MPa}$ (36 ksi).

Requirement 10 - Uncertainty of the Data and Values

The performance curve represents a lower bound to the values provided in Reference 103.

Requirement 11 - Methods used to Determine the Reported Values

The temperature-dependent tensile yield strength performance curve was developed using the tensile yield strength values provided in Reference 103. 


\begin{tabular}{|l|c|c|}
\hline $\begin{array}{l}\text { Containment Steel } \\
\text { Carbon Steel } \\
\text { Hot-Rolled Steel } \\
\text { ASME SA-36 }\end{array}$ & $\begin{array}{c}\text { Tensile Yield Strength } \\
\text { vs Temperature }\end{array}$ & $\begin{array}{r}\text { Opdate Package Number } 5 \\
\text { Revision Control Code 0.0 } \\
\text { Quality Level B }\end{array}$ \\
\hline
\end{tabular}

\begin{tabular}{|c|c|c|c|}
\hline \multirow[b]{2}{*}{$\begin{array}{l}\text { Temperature, } \\
{ }^{\circ} \mathrm{C}\left({ }^{\circ} \mathrm{F}\right)\end{array}$} & \multicolumn{3}{|c|}{$\begin{array}{l}\text { Temperature-Dependent Yield Strength } \\
\text { and Stress-Related Values, } \\
\text { MPa (ksi) }\end{array}$} \\
\hline & $\begin{array}{l}\text { Yield } \\
\text { Strength }\end{array}$ & $\begin{array}{c}\text { Maximum Allowable } \\
\text { Stress }\end{array}$ & $\begin{array}{l}\text { Design Stress } \\
\text { Intensity }\end{array}$ \\
\hline $\begin{aligned}-29 & (-20) \\
38 & (100) \\
93 & (200) \\
149 & (300) \\
204 & (400) \\
260 & (500) \\
316 & (600) \\
343 & (650) \\
371 & (700)\end{aligned}$ & $\begin{array}{ll}248 & (36.0) \\
248 & (36.0) \\
226 & (32.8) \\
220 & (31.9) \\
212 & (30.8) \\
201 & (29.1) \\
183 & (26.6) \\
180 & (26.1) \\
179 & (25.9)\end{array}$ & $\begin{array}{ll}87 & (12.6) \\
87 & (12.6) \\
87 & (12.6) \\
87 & (12.6) \\
87 & (12.6) \\
87 & (12.6) \\
87 & (12.6) \\
87 & (12.6) \\
87 & (12.6)\end{array}$ & $\begin{array}{ll}133 & (19.3) \\
133 & (19.3) \\
133 & (19.3) \\
133 & (19.3) \\
133 & (19.3) \\
133 & (19.3) \\
122 & (17.7) \\
120 & (17.4) \\
119 & (17.3)\end{array}$ \\
\hline \multicolumn{4}{|c|}{$\begin{array}{l}\text { These three sets of temperature-dependent yield strength and stress-related } \\
\text { values are provided in Section II, Part D of the ASME Boller and Pressure } \\
\text { Vessel Code (Reference } 103) \text {. The values are based on the minimum specified } \\
\text { room-temperature tensile strength [400 MPa (58 ksi)] and the minimum speci- } \\
\text { fied room-temperature tensile yield strength [24B MPa }(36 \mathrm{ks}) \text { ] for steel } \\
\text { conforming to ASME SA-36/SA-36M requirements (Reference } 97) \text {. Criteria for } \\
\text { establishing maximum allowable stress and design stress intensity values are } \\
\text { provided in Section II, Part D, Appendices } 1 \text { and } 2 \text {. } \\
\text { The values listed above are plotted on Page } 1.6 \text { along with the tensile yield } \\
\text { strength performance curves generated from the equations shown on Page } 1.5 \text {. }\end{array}$} \\
\hline
\end{tabular}


STRUCTURAL MATERIALS HANDBOOK Volume 2 - Supporting Documentation

Material Code 06AA001 Property Code $3711 \quad$ Page 1.4

\begin{tabular}{|l|l|l}
\hline Containment steel & Update Package Number 5
\end{tabular}

Carbon Steel

Hot-Rolled Steel

Tensile Yield Strength

ASME SA-36

vs Temperature

Revision Control Code 0.0 Qual1ty Level B

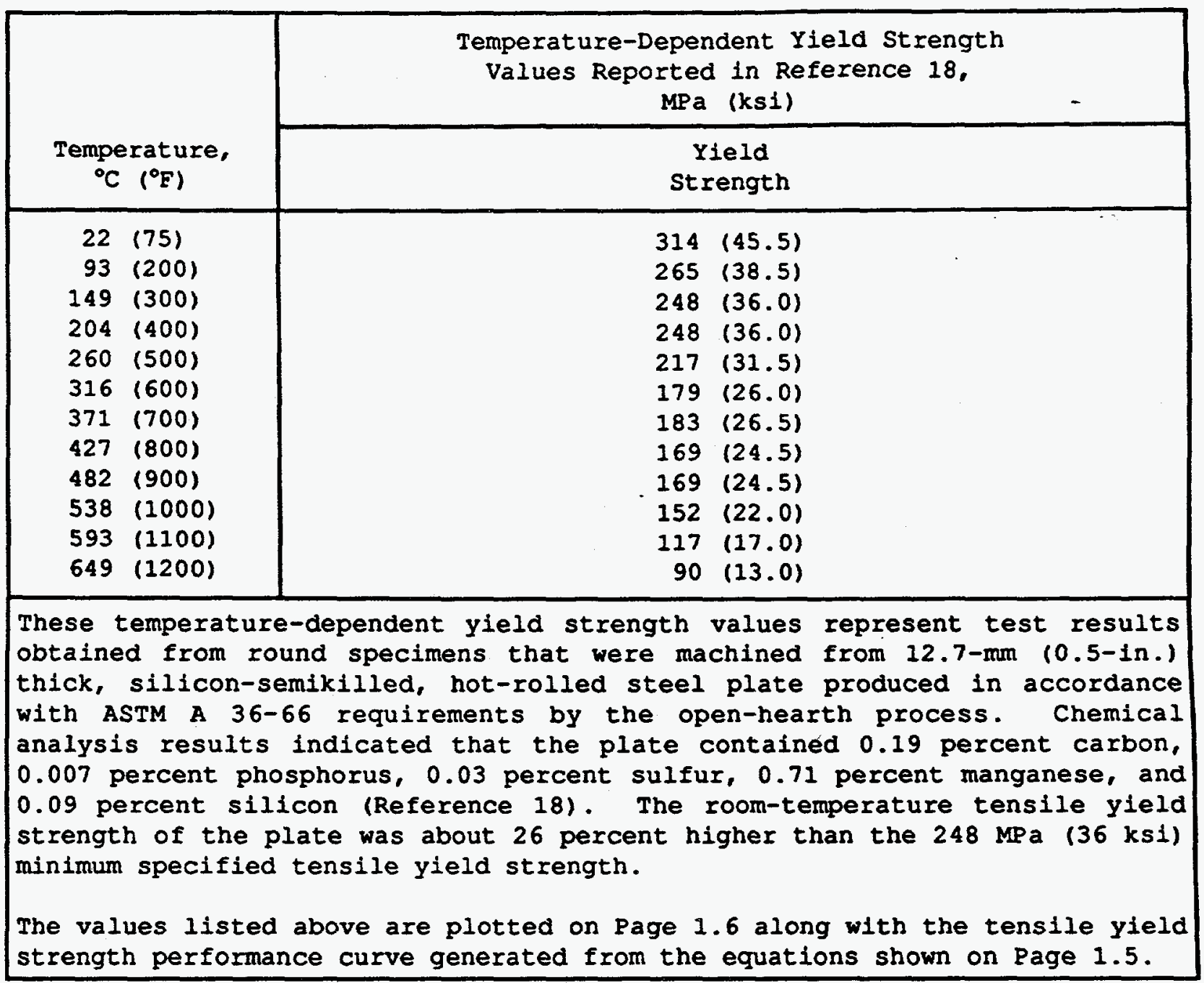


STRUCTURAL MATERIALS HANDBOOK Volume 2 - Supporting Documentation

Material Code 06AAO01

Property Code 3711

Page 1.5

Containment steel

Carbon steel

Hot-Rolled Steel

Tensile Yield Strength

ASME SA-36

vs Temperature

Update Package Number 5

Revision Control code 0.0

Quality Level $B$

The tensile yield strength performance curve shown on Page 1.6 reflects the tensile yield strength values provided in section II, Part D of the ASME Boiler and Pressure Vessel Code (Reference 103) for containment steel conforming to ASME SA-36/SA-36M requirements (Reference 97). The equations used to generate the tensile yield strength performance curve are shown below. These equations were developed using the tensile yield strength values listed on Page 1.3 and are only valid over the specified temperature ranges.

$\mathrm{FY}=233-0.191$ (T) MPa $\quad$ for $-29^{\circ} \mathrm{C} \leq \mathrm{T} \leq 371^{\circ} \mathrm{C}$

Where $F y$ is the tensile yield strength, and $T$ is the temperature in degrees Celsius.

or

$f y=34.3-0.0154$ (t) $\mathrm{ksi} \quad$ for $-20^{\circ} \mathrm{F} \leq t \leq 700^{\circ} \mathrm{F}$

Where $f_{y}$ is the tensile yield strength, and $t$ is the temperature in degrees Fahrenheit. 
STRUCTURAL MATERIALS HANDBOOK Volume 2 - Supporting Documentation

$\begin{array}{lll}\text { Material Code 06AA001 } & \text { Property Code } 3711 & \text { Page } 1.6\end{array}$

Containment steel

Carbon Steel

Hot-Rolled steel

ASME SA-36

Tensile Yield Strength

vs Temperature
Update Package Number 5 Revision control code 0.0 Quality Level B

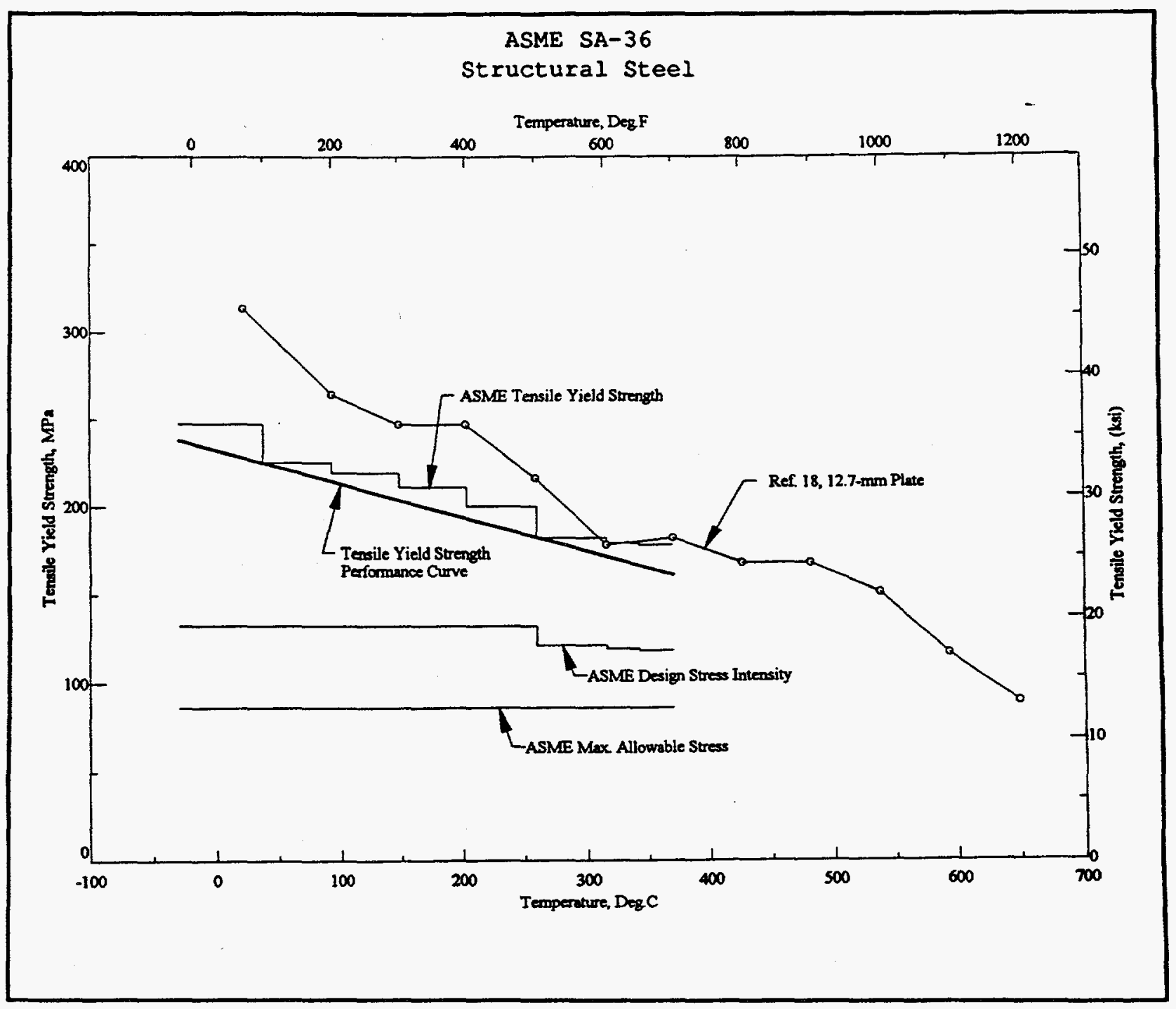

The values plotted on the graph above are listed on Pages 1.3 and 1.4. The tensile yield strength performance curve was calculated from the equations shown on Page 1.5 .

Sources: References 18, 97, 100, and 103. 
STRUCTURAL MATERIALS HANDBOOK Volume 2 - Supporting Documentation

Material Code 06AA001

Property Code 3712

Page 2.1

\begin{tabular}{|l|l}
\hline Containment steel & Ultimate Tensile
\end{tabular}

Carbon steel

Hot-Rolled steel

ASME SA-36 strength

vs Temperature
Update Package Number 5 Revision Control Code 0.0 Quality Level $B$

\author{
Preparer: C. B. Oland \\ Organization: Oak Ridge National Laboratory \\ Sources: References 18, 97, 100, and 103
}

\begin{abstract}
Information Sources
Reference 18: ASTM STP 464. This information source contains mechanical properties at elevated temperatures for three metallic materials including ASTM A 36 structural steel.

Reference 97: ASME Material Specification SA-36/SA-36M. This material specification contains chemical and strength requirements for a carbonmanganese-silicon steel intended for use in construction of buildings and bridges and in containment pressure vessel applications. This specification is identical to ASTM A 36/A 36M (Reference 100).

Reference 100: ASTM Material Specification A 36/A 36M. This material specification contains chemical and strength requirements for a carbonmanganese-silicon steel intended for use in construction of buildings and bridges and in containment pressure vessel applications. This specification is identical to ASME SA-36/SA-36M (Reference 97).

Reference 103: ASME Boiler and Pressure Vessel Code - Section II, Part D. This information source contains temperature-dependent material properties for steels permitted for use in construction of containment pressure boundary components.
\end{abstract}


STRUCTURAL MATERIALS HANDBOOK

Volume 2 - Supporting Documentation

Material code 06AA001

Property Code 3712

Page 2.2

Containment steel

Carbon steel

Hot-Rolled Steel

ASME SA-36

Ultimate Tensile

Strength

vs Temperature
Opdate Package Number 5 Revision Control Code 0.0 Quality Level B

"Selected Property" - Evaluation for Quality Level B

Requirement 1 - Completeness of Material Description

The material conforms to ASME SA-36/SA-36M and ASTM A 36/A 36M requirements.

These material specifications are identical.

Requirement 2 - Stability of the Material

The material is stable at temperatures up to $649^{\circ} \mathrm{C}\left(1,200^{\circ} \mathrm{F}\right)$.

Requirement 3 - Type of Input from the References and Sources

Temperature-dependent tensile yield strength values are reported.

Requirement 4 - Completeness of Data and Values Search

Values for $12.7-\mathrm{mm}(0.5-i n)$ thick steel plates are reported in Reference 18.

Requirement 5 - Completeness of Resources

Values at temperatures ranging from 22 to $649^{\circ} \mathrm{C}\left(75\right.$ to $\left.1,200^{\circ} \mathrm{F}\right)$ are reported.

Requirement 6 - Quality of the References or Sources

The values reported in Reference 103 were developed specifically for steel conforming to ASME SA-36/SA-36M requirements. However, tensile strength values are not listed and reasons for the omission were not presented.

Requirement 7 - Availability of Data and Values

Values at 12 temperatures are provided in Reference 18.

Requirement 8 - Consistency of the Data and Values with Respect to Related Properties

Reported yield strength values are consistent with other sets of yield strength values reported for other steels with similar compositions.

Requirement 9 - Precision or Scatter of the Data or Values

Reported values are typical for this type of low-carbon steel with a minimum specified tensile strength of $400 \mathrm{MPa}$ (58 ksi).

Requirement 10 - Uncertainty of the Data and Values

The uncertainty of the values reported in Reference 18 could not be assessed because testing details were not provided.

Requirement 11 - Methods used to Determine the Reported Values

A performance curve was not developed because temperature-dependent tensile strength values were not provided in Reference 103. 
STRUCTURAL MATERIALS HANDBOOK Volume 2 - Supporting Documentation

Material Code 06AAO01

Property Code 3712

Page 2.3

Contalnment steel

Carbon Steel

Ultimate Tensile

Strength

Hot-Rolled Steel

ASME SA-36

vs Temperature

Update Rackage Number 5 Revision Control Code 0.0 Quality Level B

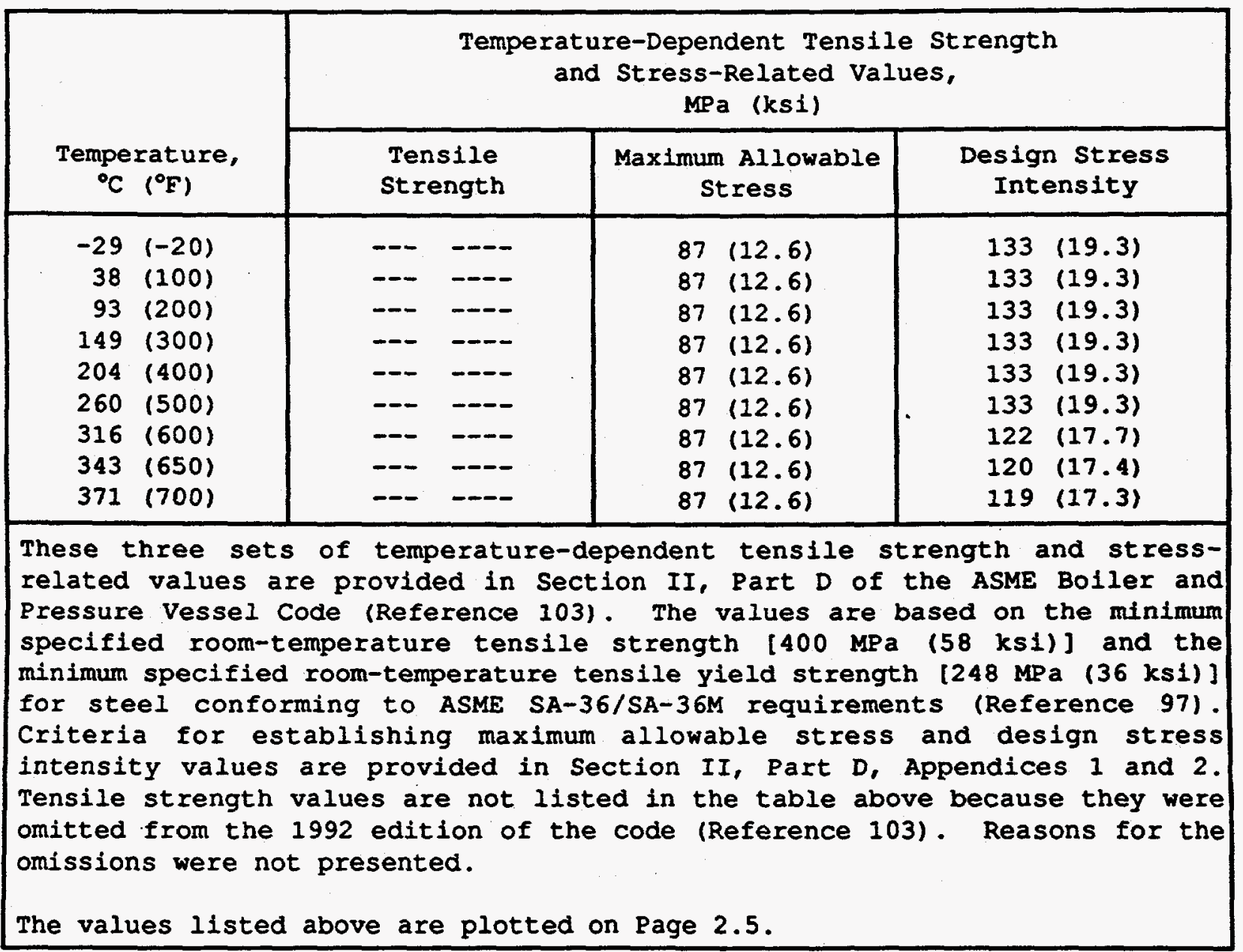


STRUCTURAL MATERIALS HANDBOOK Volume 2 - Supporting Documentation

Material Code 06AAOOI

Property Code 3712

Page 2.4

Containment Steel

Carbon steel

Hot-Rolled steel

ASME SA-36

Ultimate Tensile Strength

vs Temperature
Opdate Package Number 5 Revision Control code 0.0 Quality Level B

\begin{tabular}{|c|c|}
\hline \multirow[b]{2}{*}{$\begin{array}{c}\text { Temperature, } \\
{ }^{\circ} \mathrm{C}\left({ }^{\circ} \mathrm{F}\right)\end{array}$} & $\begin{array}{c}\text { Temperature-Dependent Tensile Strength } \\
\text { Values Reported in Reference 18, } \\
\text { MPa (ksi) }\end{array}$ \\
\hline & $\begin{array}{l}\text { Tensile } \\
\text { Strength }\end{array}$ \\
\hline $\begin{aligned} 22 & (75) \\
93 & (200) \\
149 & (300) \\
204 & (400) \\
260 & (500) \\
316 & (600) \\
371 & (700) \\
427 & (800) \\
482 & (900) \\
538 & (1000) \\
593 & (1100) \\
649 & (1200)\end{aligned}$ & $\begin{array}{ll}445 & (64.5) \\
407 & (59.0) \\
438 & (63.5) \\
479 & (69.5) \\
496 & (72.0) \\
467 & (67.8) \\
441 & (64.0) \\
365 & (53.0) \\
305 & (44.3) \\
241 & (35.0) \\
172 & (25.0) \\
117 & (17.0)\end{array}$ \\
\hline \multicolumn{2}{|c|}{$\begin{array}{l}\text { These temperature-dependent tensile strength values represent test results } \\
\text { obtained from round specimens that were machined from } 12.7-\mathrm{mm}(0.5-1 \mathrm{n} .) \\
\text { thick, silicon-semikilled, hot-rolled steel plate produced in accordance } \\
\text { with ASTM A } 36-66 \text { requirements by the open-hearth process. Chemlcal } \\
\text { analysis results indicated that the plate contained } 0.19 \text { percent carbon, } \\
0.007 \text { percent phosphorus, } 0.03 \text { percent sulfur, } 0.71 \text { percent manganese, and } \\
0.09 \text { percent silicon (Reference } 18 \text { ). The room-temperature tensile strength } \\
\text { of the plate was about } 11 \text { percent higher than the } 400 \mathrm{MPa}(58 \mathrm{ksi} \text { minimum } \\
\text { specified tensile strength. } \\
\text { The values listed above are plotted on Page } 2.6 \text {. }\end{array}$} \\
\hline
\end{tabular}


STRUCTURAL MATERIALS HANDBOOK Volume 2 - Supporting Documentation

Material Code 06AA001

Property Code 3712

Page 2.5

Containment steel

Carbon steel

Hot-Rolled Steel

ASME SA-36
Ultimate Tensile

Strength

vs Temperature
Update Package Number 5

Revision Control code 0.0 Quality Level B

The tensile strength performance curve that should appear on Page 2.6 was not developed because tensile strength values are not provided in Section II, Part D of the ASME Boiler and pressure vessel Code (Reference 103) for containment steel conforming to ASME SA-36/SA-36M requirements (Reference 97 ). See Page 2.3 for additional information. 


\section{STRUCTURAL MATERIALS HANDBOOK Volume 2 - Supporting Documentation}

Material Code 06AA001

Property Code 3712

Page 2.6

Containment steel

Carbon steel

Hot-Rolled Steel

ASME SA-36

Ultimate Tensile

Strength

vs Temperature
Opdate Package Number 5 Revision Control code 0.0 Quality Level B

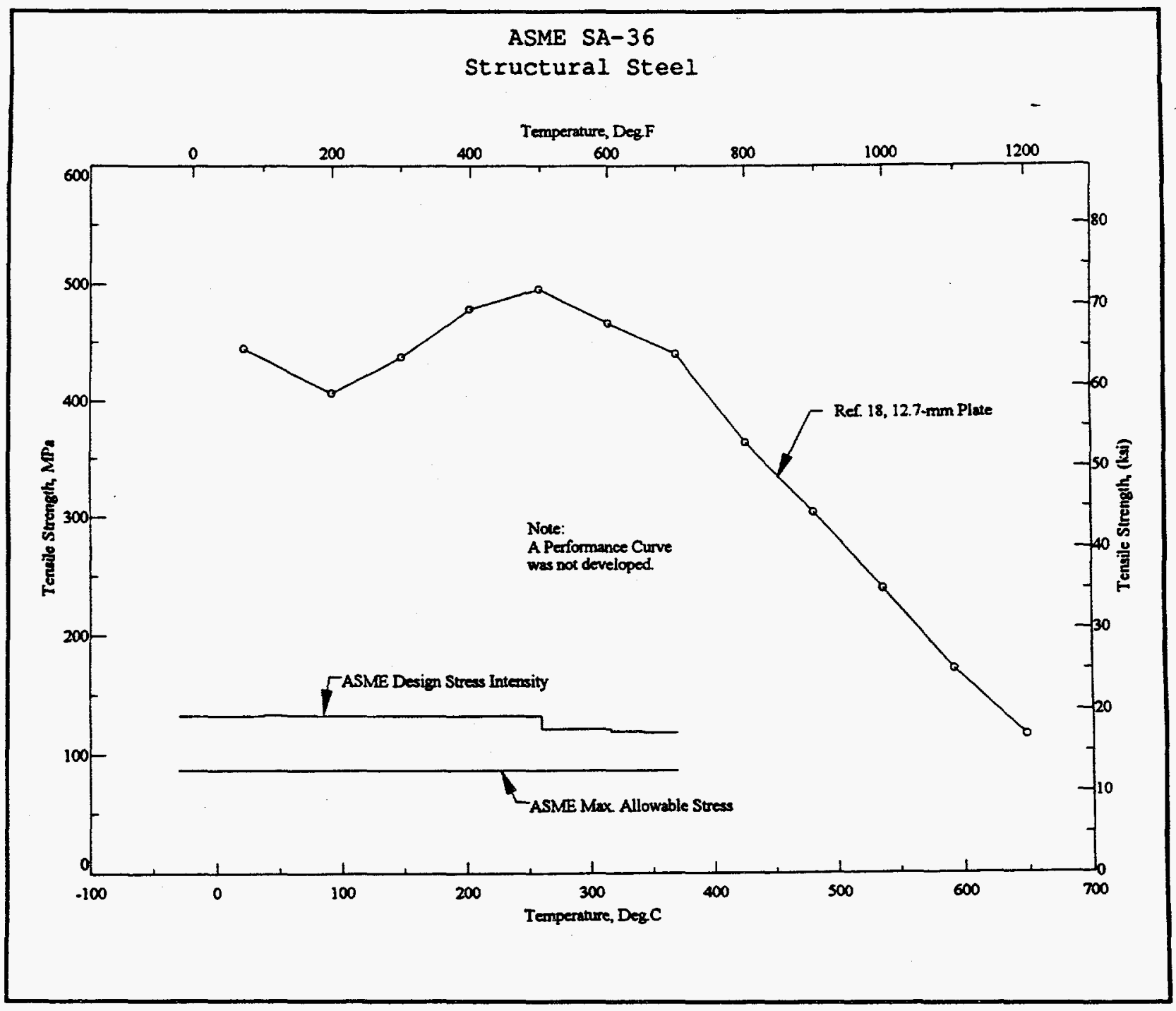

The values plotted on the graph above are listed on Pages 2.3 and 2.4. The reason the temperature-dependent tensile strength performance curve was not developed is explained on Page 2.5.

Sources: References $18,97,100$, and 103. 


\section{STRUCTURAL MATERIALS HANDBOOK Volume 2 - Supporting Documentation}

Material Code 06AA001

Property Code 3713

Page 3.1

Containment steel

Carbon steel

Hot-Rolled steel

ASME SA-36
Tensile Yield Strength Rat io vs Temperature
Update Package Number 5 Revision control code 0.0 Quality Level B

Preparer: C. B. Oland

Organization: Oak Ridge National Laboratory

Sources: References 17, 18, 22, 97, 100, and 103

\section{Information Sources}

Reference 17: Steel Design Manual. This information source contains material properties for a variety of structural steels including ASTM A 36 structural steel.

Reference 18: ASTM STP 464. This information source contains mechanical properties at elevated temperatures for three metallic materials including ASTM A 36 structural steel.

Reference 22: AISC Manual of Steel Construction Allowable Stress Design. This information source contains elevated-temperature material properties for carbon and high-strength low-alloy steels.

Reference 97: ASME Material Specification SA-36/SA-36M. This material specification contains chemical and strength requirements for a carbonmanganese-silicon steel intended for use in construction of bulldings and bridges and in containment pressure vessel applications. This specification is identical to ASTM A 36/A 36M (Reference 100).

Reference 100: ASTM Material Specification A 36/A 36M. This material specification contains chemical and strength requirements for a carbonmanganese-silicon steel intended for use in construction of buildings and bridges and in containment pressure vessel applications. This specification is identical to ASME SA-36/SA-36M (Reference 97).

Reference 103: ASME Boiler and Pressure Vessel Code - Section II, Part D. This information source contains temperature-dependent material properties for steels permitted for use in construction of containment pressure boundary components. 


\begin{tabular}{|c|c|c|}
\hline $\begin{array}{l}\text { Contalnment steel } \\
\text { Carbon steel } \\
\text { Hot-Rolled Steel } \\
\text { ASME SA-36 }\end{array}$ & $\begin{array}{c}\text { Tensile Yield Strength } \\
\text { Ratio vs Temperature }\end{array}$ & $\begin{array}{r}\text { Update Package Number } 5 \\
\text { Revision Control Code } 0.0 \\
\text { Quality Level B }\end{array}$ \\
\hline
\end{tabular}

"Selected Property" - Evaluation for Quality Level B

Requirement 1 - Completeness of Material Description

The material conforms to ASME SA-36/SA-36M and ASTM A 36/A 36M requirements.

These material specifications are identical.

Requirement 2 - Stability of the Material

The material is stable at temperatures up to $649^{\circ} \mathrm{C}\left(1,200^{\circ} \mathrm{F}\right)$.

Requirement 3 - Type of Input from the References and Sources

Temperature-dependent tensile yield strength values are reported.

Requirement 4 - Completeness of Data and Values Search

values for other carbon steels are available, but values reported in References 17, 18, and 103 were developed specifically for this steel.

Requirement 5 - Completeness of Resources

Values at temperatures ranging from -29 to $649^{\circ} \mathrm{C}\left(-20\right.$ to $\left.1,200^{\circ} \mathrm{F}\right)$ are reported.

Requirement 6 - Quality of the References or Sources

The values reported in Reference 103 were developed specifically for steel conforming to ASME SA-36/SA-36M requirements. However, references containing the data and test results used to establish these values were not identified.

Requirement 7 - Availability of Data and Values

Values at 12 temperatures are provided in Reference 18.

Requirement 8 - Consistency of the Data and Values with Respect to Related Properties

Reported yield strength values are consistent with other sets of yield strength values reported for other steels with similar compositions.

Requirement 9 - Precision or Scatter of the Data or Values

Reported values are typical for this type of low-carbon steel with a minimum specified yield strength of $448 \mathrm{MPa}$ (36 ksi).

Requirement 10 - Uncertainty of the Data and Values

The performance curve represents a lower bound to the values provided in Reference 103.

Requirement 11 - Methods used to Determine the Reported Values The performance curve shown on Page 3.5 was developed using the tensile yield strength values provided in Reference 103. 
STRUCTURAL MATERIALS HANDBOOK

Property Code

Volume 2 - Supporting

3713

Tensile Yield Strength Ratio vs Temperature
Update Package Number 5

Revision Control code 0.0 Quality Level B

ASME SA-36

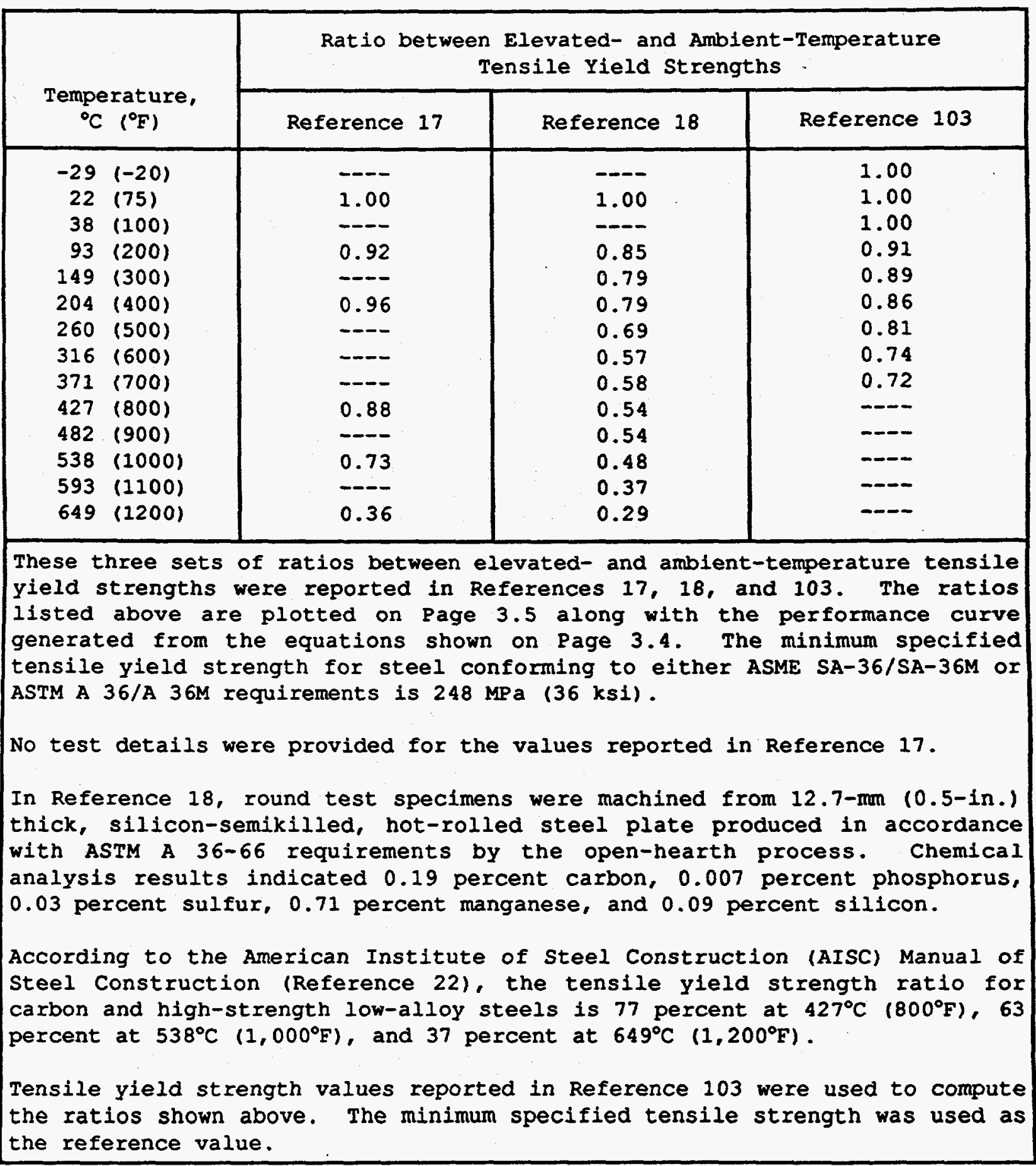


STRUCTURAL MATERIALS HANDBOOK Volume 2-Supporting Documentation

Material Code 06AA001

Property Code 3713

Page 3.4

Contalnment steel

Carbon steel

Hot-Rolled Steel

Tensile Yield strength

ASME SA-36

Ratio vs Temperature

Opdate Package Number 5

Revision Control code 0.0

Quality Level B

The performance curve shown on Page 3.5 reflects the tensile yield strength values provided in Section II, Part D of the ASME Boiler and Pressure Vessel Code (Reference 103) for containment steel conforming to ASME SA-36/SA-36M requirements (Reference 97). The equations used to generate the performance curve were developed using the values listed on page 3.3 and are only valid over the specified temperature ranges.

$R=0.939-7.660 \times 10^{-4}(T)$

for $-29^{\circ} \mathrm{C} \leq \mathrm{T} \leq 371^{\circ} \mathrm{C}$

Where $R$ is the ratio between elevated- and ambient-temperature tensile yield strengths, and $T$ is the temperature in degrees Celsius.

or

$r=0.953-4.260 \times 10^{-4}(t)$

for $-20^{\circ} \mathrm{F} \leq t \leq 700^{\circ} \mathrm{F}$

Where $r$ is the ratio between elevated- and ambient-temperature tensile yield strengths, and $t$ is the temperature in degrees Fahrenheit. 
STRUCTURAL MATERIALS HANDBOOK Volume 2 - Supporting Documentation Material Code 06AA001

Property Code 3713

Page 3.5

Containment steel

Carbon steel

Hot-Rolled Steel

ASME SA-36

Tensile Yield Strength

Ratio vs Temperature
Update Package Number 5 Revision Control Code 0.0 Quality Level $\mathrm{B}$

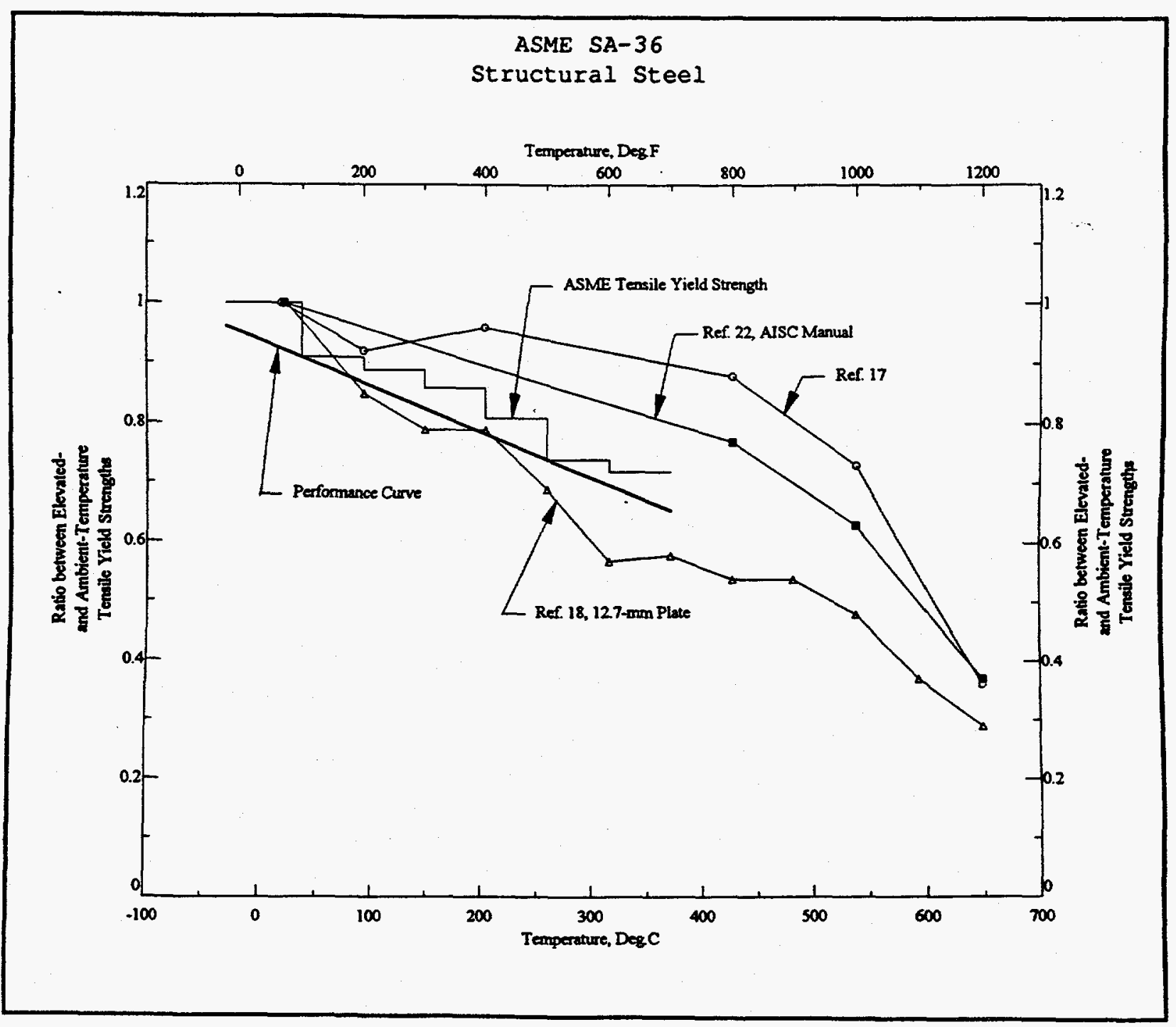

The values plotted on the graph above are listed on Page 3.3. The performance curve was calculated from the equations shown on Page 3.4. Sources: References 17, 18, 22, 97, 100, and 103 . 


\section{STRUCTURAL MATERIALS HANDBOOK}

Volume 3 - Material Data Sheets

Chapter 6 - Containment Steels 
STRUCTURAL MATERIALS HANDBOOK

Volume 3 - Material Data Sheet

Material Code 06 AAO01

Property Code 1000

Page 1

Containment Steel

Carbon steel

Hot-Rolled steel

ASME SA-36

General

Information
Update Package Number 5 Revision Control Code 0.0 Quality Level B

Property Code 1010

Descriptive Information

This steel conforms to ASME SA-36/SA-36M (Reference 97) material specification requirements and is permitted for use in construction of metal and concrete containment pressure boundary components by the ASME Boiler and Pressure Vessel Code (References 98 and 99). This steel also conforms to ASTM A 36/A 36M-90 material specification requirements and is used to manufacture structural shapes, plates, and bars for general structural purposes (Reference 100). Material specifications ASME SA-36/SA-36M and ASTM A 36/A 36M-90 are identical. The UNS designation (Reference 104) for this steel is K02600.

ASTM A 36 was originally published in 1960 as a tentative specification and formally adopted in 1966. In 1984, material standards corresponding to the SI (metric) system were incorporated into the specification. Because of this change, values appearing in the specification are stated either in inch-pound or SI units. However, the values are not exact equivalents, and each system must be used independent of the other.

The values that appear in parenthesis in this handbook are presented in inch-pound units and are to be considered standard. Corresponding values presented in SI units are equivalent to the standard values.

Property Code 1110

Material Characteristics

Material conforming to ASME SA-36/SA-36M or ASTM A $36 / \mathrm{A} 36 \mathrm{M}$ requirements is categorized as low-carbon steel (carbon $\leq 0.30$ percent) with a nominal carbon-manganese-silicon composition. It is weldable and ductile and has a minimum yield point of $248 \mathrm{MPa}(36 \mathrm{ksi})$. However, its toughness is relatively low, and its chemical requirements are both form and thickness dependent.

This steel is used primarily to fabricate structural components that support relatively low stresses. These components are typically riveted, bolted, or welded together and used to construct bridges and buildings. This steel is also permitted for use in construction of concrete containment liners and metal containment supports by the ASME Boiler and Pressure vessel Code (References 98 and 99 ). 


General
nformation

Update Package Number 5 Revision Control code 0.0 Quality Level B

\begin{tabular}{|l|c|}
\hline Property Code 1210 & Material composition \\
\hline The manufacturer is required to perform an analysis of each heat of steel to \\
determine the percentages of carbon, manganese, phosphorous, sulfur, \\
silicon, and, when specifically instructed, copper, columbium, chromium, \\
nickel, molybdenum, and vanadium. Heat analysis requirements are shown on \\
Page 3 or 4 except for plates over $40-$ mm $(1.5-1 n$.$) thick used as bearing$ \\
plates in structures other than bridges. For these applications, the carbon \\
requirement ranges from 0.20 to 0.33 percent, and the phosphorus and sulfur \\
content requirements are the same as those shown on Page 4 . \\
The tolerances for the product analysis are defined in section 7 of \\
Reference 101 or 102 as appropriate.
\end{tabular}


General

Information
Update Package Number 5 Revision Control Code 0.0 Quality Level B

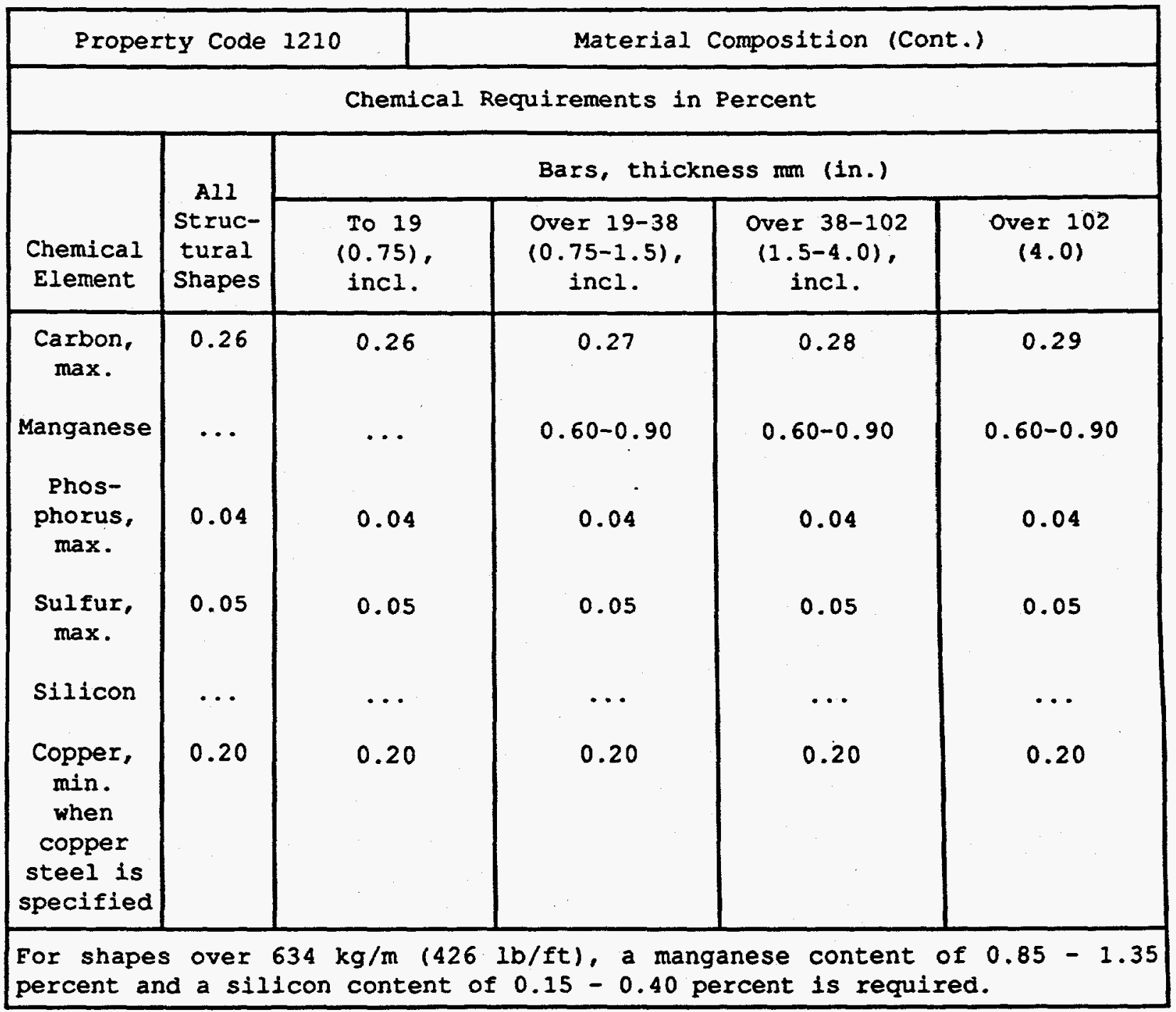


STRUCTURAL MATERIALS HANDBOOK

Volume 3 - Material Data Sheet

Material Code 06AA001

Property Code 1000

Page 4

Containment steel

Carbon Steel

Hot-Rolled steel

ASME SA-36

General

Information
Dpdate Package Number 5 Revision Control code 0.0 Quality Level B

\begin{tabular}{|c|c|c|c|c|c|}
\hline \multicolumn{2}{|c|}{ Property Code 1210} & \multicolumn{4}{|c|}{ Material Composition (Cont.) } \\
\hline \multicolumn{6}{|c|}{ Chemical Requirements in Percent } \\
\hline \multirow[b]{2}{*}{$\begin{array}{l}\text { Chemical } \\
\text { Element }\end{array}$} & \multicolumn{5}{|c|}{ Plates, thickness $\mathrm{mm}$ (in.) } \\
\hline & $\begin{array}{l}\text { To } 19 \\
(0.75) \\
\text { incl. }\end{array}$ & $\begin{array}{c}\text { Over } 19-38 \\
(0.75-1.5) \\
\text { incl. }\end{array}$ & $\begin{array}{c}\text { Over } 38-64 \\
(1.5-2.5) \\
\text { incl. }\end{array}$ & $\begin{array}{c}\text { Over } 64-102 \\
(2.5-4.0) \\
\text { incl. }\end{array}$ & $\begin{array}{c}\text { Over } 102 \\
(4.0)\end{array}$ \\
\hline $\begin{array}{c}\text { Carbon, } \\
\max .\end{array}$ & 0.25 & 0.25 & 0.26 & 0.27 & 0.29 \\
\hline Manganese & $\cdots$ & $0.80-1.20$ & $0.80-1.20$ & $0.85-1.20$ & $0.85-1.20$ \\
\hline $\begin{array}{c}\text { Phos- } \\
\text { phorus, } \\
\text { max. }\end{array}$ & 0.04 & 0.04 & 0.04 & 0.04 & 0.04 \\
\hline $\begin{array}{l}\text { Sulfur, } \\
\max .\end{array}$ & 0.05 & 0.05 & 0.05 & 0.05 & 0.05 \\
\hline Silicon & $\cdots$ & $\cdots$ & $0.15-0.40$ & $0.15-0.40$ & $0.15-0.40$ \\
\hline $\begin{array}{l}\text { Copper, } \\
\text { min. } \\
\text { when } \\
\text { copper } \\
\text { steel is } \\
\text { specified }\end{array}$ & 0.20 & 0.20 & 0.20 & 0.20 & 0.20 \\
\hline
\end{tabular}


Contalnment steel

Carbon Steel

Hot-Rolled steel

ASME SA-36

General

Information
Opdate Package Number 5 Revision Control Code 0.0 Quality Level B

\footnotetext{
Property Code 1220

Processing Information (Cont.)

Supolementary Requirements

Standardized supplementary requirements including Charpy V-notch impact and bend testing may be specified in the order. These requirements are stated in Reference 101 or 102 as appropriate.

\section{Weight Requirements}

The unit weight of rolled steel is assumed to be $7,850 \mathrm{~kg}$ per cubic meter (490 16 per cubic foot).

The permitted weight variation for plates is specified in Reference 101 or 102 as appropriate. The weight variation for structural shapes and bars depends on the appropriate dimensional tolerances permitted in Reference 101 or 102 as appropriate.
}

This steel may be successfully welded provided an appropriate welding procedure is selected and used. As a minimum, this procedure must be suitable for use with this steel and should reflect the type and geometry of the components being welded. Thickness-dependent minimum preheat or interpass temperatures for welding with low-hydrogen electrodes are provided in Reference 113. 
STRUCTURAL MATERIALS HANDBOOK

Volume 3 - Material Data Sheet

Material Code 06AA001

Property Code 1000

Page 7

Containment steel.

Carbon steel

Hot-Rolled steel

ASME SA-36

General

Information
Update Package Number 5 Revision Control Code 0.0 Quality Level B

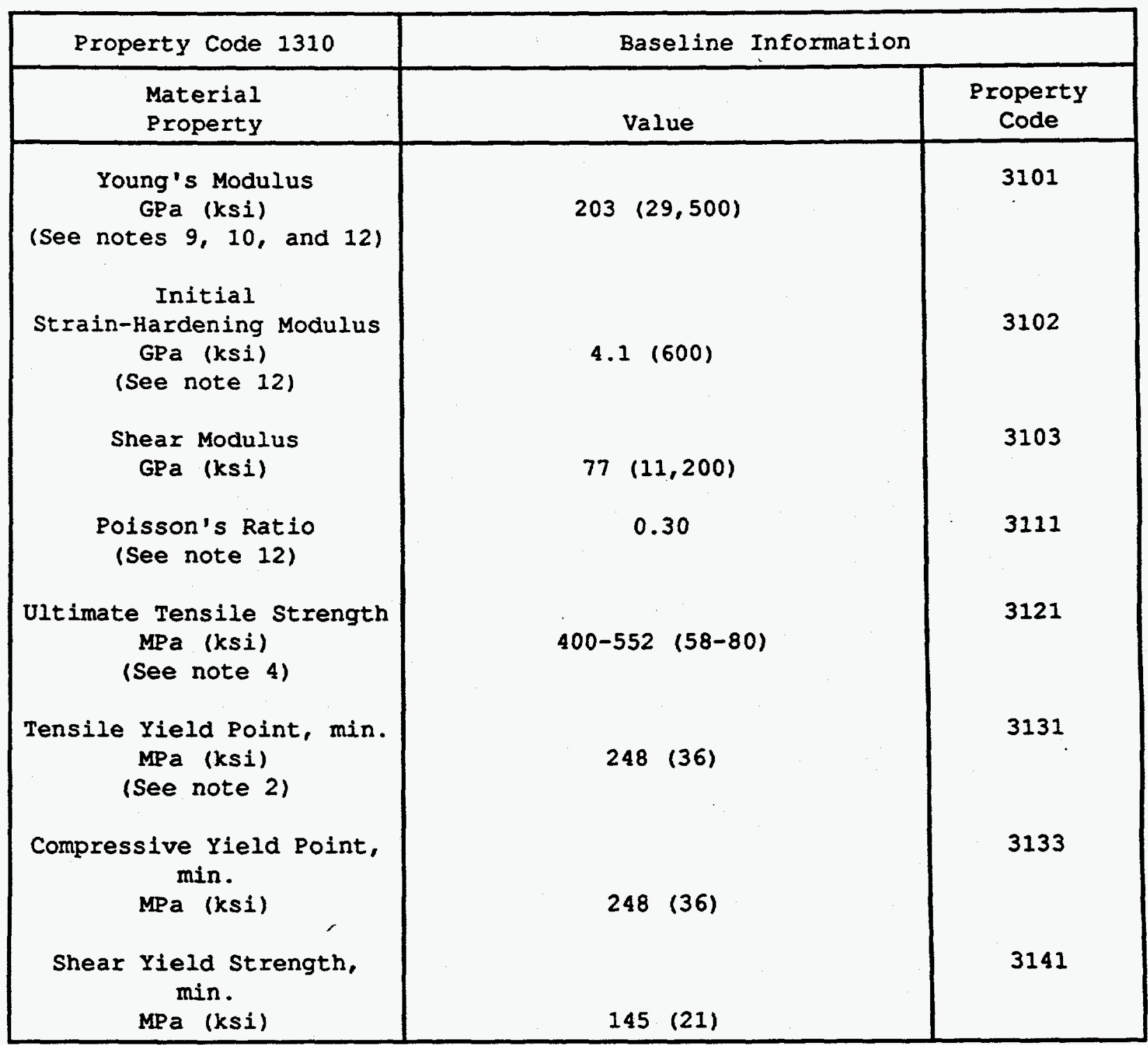




\begin{tabular}{|l|c|r|}
\hline \begin{tabular}{l|l} 
Containment Steel \\
Carbon Steel \\
Hot-Rolled Steel
\end{tabular} & General \\
ASME SA-36 & Information & $\begin{array}{r}\text { Update Package Number } 5 \\
\text { Revision Control Code } 0.0 \\
\text { Quality Level B }\end{array}$ \\
\hline
\end{tabular}

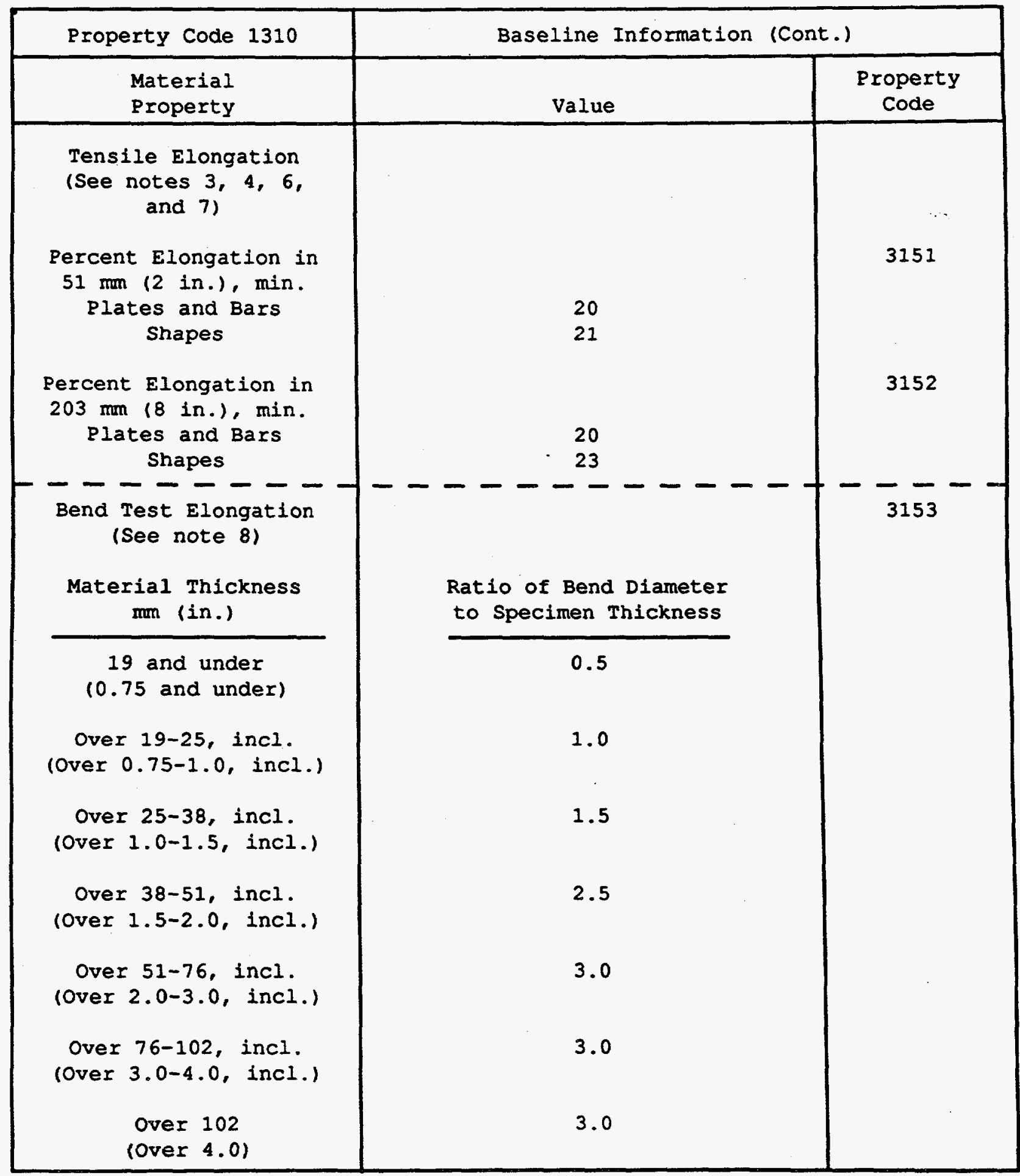


STRUCTURAL MATERIALS HANDBOOK

Volume 3 - Material Data Sheet

Material Code 06AAO01

Property Code 1000

Page 9

Containment steel

Carbon steel

Hot-Rolled steel

General

ASME SA-36

Information

Update Package Number 5

Revision Control Code 0.0

quality Level B

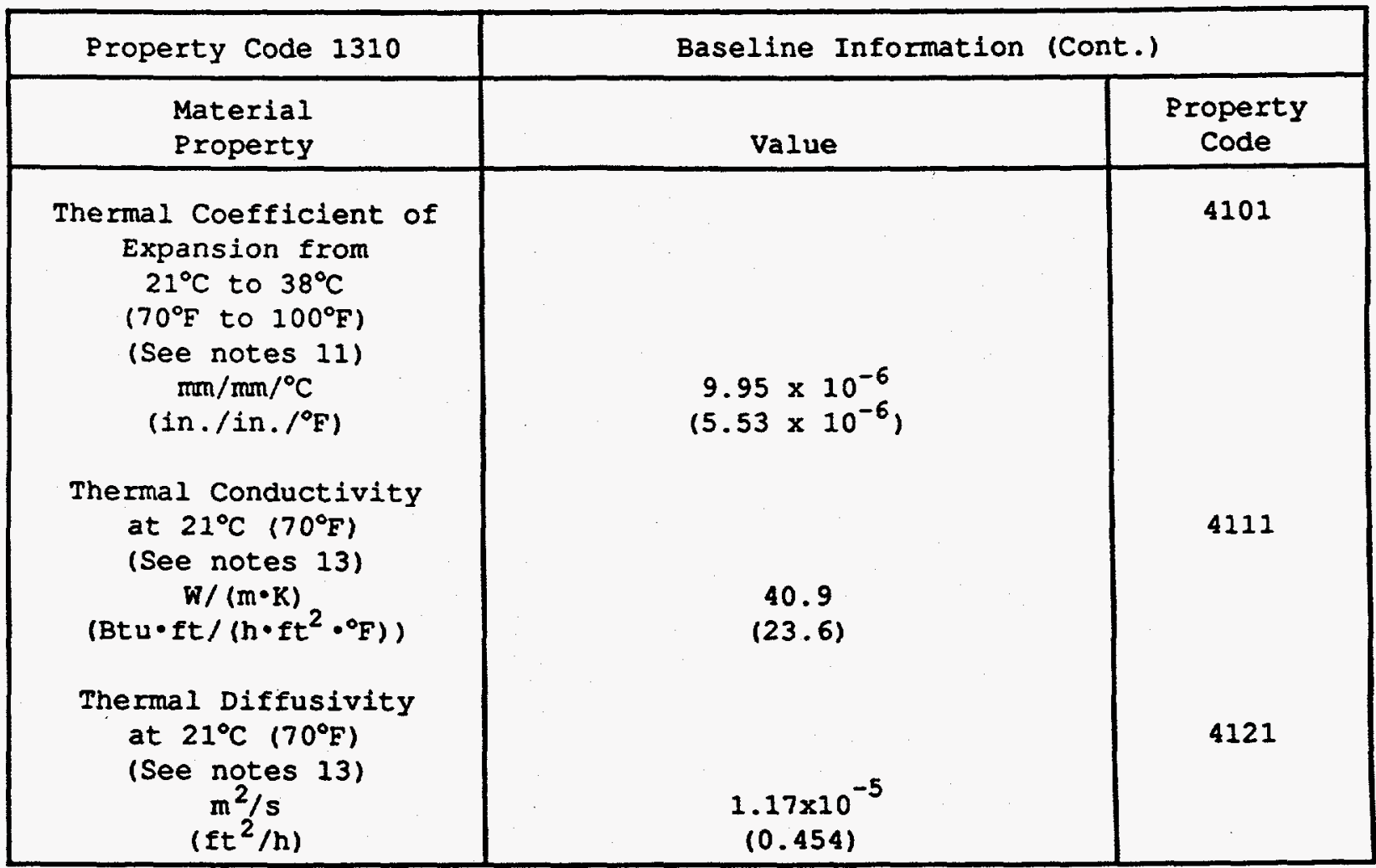


General

ASME SA-36
Information
Update Package Number 5 Revision Control code 0.0 Qual1ty Level B

Note 1: For plates wider than $610 \mathrm{~mm}(24 \mathrm{in.})$, the test specimen is taken in the transverse direction as specified in Section 11.2 of Reference 101 or 102 as appropriate.

Note 2: For plates thicker than $203 \mathrm{~mm}(8 \mathrm{in.})$, the minimum yield point is $221 \mathrm{MPa}(32 \mathrm{ksi})$.

Note 3: For plates wider than $610 \mathrm{~mm}$ (24 in.), the elongation requirement is reduced two percentage points.

Note 4: For wide flange shapes over $634 \mathrm{~kg} / \mathrm{m}(426 \mathrm{lb} / \mathrm{ft})$, the $552 \mathrm{MPa}$ ( $80 \mathrm{ksi})$ maximum tensile strength does not apply but a minimum elongation in $51 \mathrm{~mm}$ ( 2 in.) of 19 percent applies.

Note 5: Shapes less than $645 \mathrm{sq}$. $\mathrm{mm}$ (1 sq. in.) in cross section and bars, other than flats, less than $12.7 \mathrm{~mm}(0.5 \mathrm{in.})$ in thickness need not be subjected to tension tests.

Note 6: For material thickness or diameter under $8 \mathrm{~mm}(5 / 16 \mathrm{in.})$, a deduction from the specified percentage of elongation in $203 \mathrm{~mm}(8$ in.) shall be made for decreases of the nominal thickness or diameter below $8 \mathrm{~mm}(5 / 16 \mathrm{in.})$. Adjustment values are provided in section 11.6 of Reference 101 or 102 as appropriate.

Note 7: For material thickness or diameter over $89 \mathrm{~mm}(3.5$ in.), a deduction from the specified percentage of elongation in $51 \mathrm{~mm}(2 \mathrm{in.})$ shall be made for increases of the nominal thickness or diameter above $89 \mathrm{~mm}$ ( $3.5 \mathrm{in.)}$. Adjustment values are provided in section 11.6 of Reference 101 or 102 as appropriate.

Note 8: The bend test elongation ratios shown on Page 8 and prescribed in Table S1.1 of Reference 101 or 102 as appropriate are supplementary requirements that may be requested by the purchaser. These ratios apply to the bending performance of a test specimen only. This specimen is always taken in the longitudinal direction and usually has some edge preparation.

Note 9: The modulus of elasticity for structural steel is approximately $200 \mathrm{GPa}(29,000 \mathrm{ksi})$ at $21^{\circ} \mathrm{C}\left(70^{\circ} \mathrm{F}\right)$ and decreases linearly to about $172 \mathrm{GPa}(25,000 \mathrm{ksi})$ at $482^{\circ} \mathrm{C}\left(900^{\circ} \mathrm{F}\right)$. At higher temperatures, the modulus of elasticity decreases at a faster rate (Reference 22 ).

Note 10: Based on tabulated values provided in Reference 103, the modulus of elasticity for carbon steels with less than 0.30 percent carbon is $203 \mathrm{GPa}(29,500 \mathrm{ksi})$ at $21^{\circ} \mathrm{C}\left(70^{\circ} \mathrm{F}\right)$ and decreases from a value of $217 \mathrm{GPa}(31,400 \mathrm{ksi})$ at $-198^{\circ} \mathrm{C}\left(-325^{\circ} \mathrm{F}\right)$ to $154 \mathrm{GPa}(22,400 \mathrm{ksi})$ at $482^{\circ} \mathrm{C}\left(900^{\circ} \mathrm{F}\right)$. 
STRUCTURAL MATERIALS HANDBOOK

Volume 3 - Material Data Sheet

Material Code 06AA001

Property Code 1000

Page 11

Containment steel

Carbon steel

Hot-Rolled steel

ASME SA-36

General

Information
Opdate Package Number 5 Revision Control code 0.0 Quality Level $B$

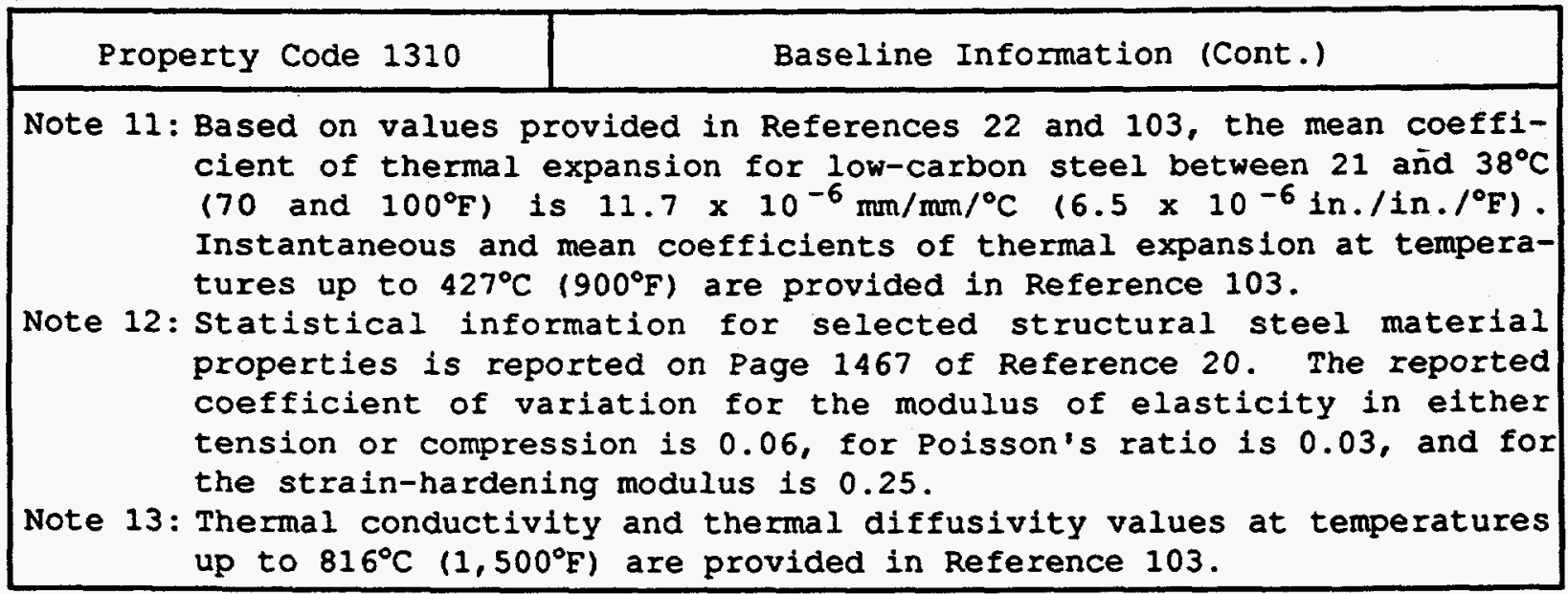


The permissible variation in dimensions or weight [mass] for structural shapes, plates, and bars produced from this steel are identified in section 13 of Reference 101 or 102 as appropriate. Due to the extent of these requirements, dimensional product standards are not included in the handbook. 
STRUCTURAL MATERIALS HANDBOOK

Volume 3 - Material Data Sheet

Material Code 06AA001

Property Code 1000

Page 13

Contalnment steel

Carbon steel

Hot-Rolled steel

General

ASME SA-36

Information

Update Package Number 5

Revision Control Code 0.0

Quality Level B

\section{Reference Documentation}

17. R. L. Brockenbrough and B. G. Johnson, Steel Design Manual, United States Steel Corp., Pittsburgh, Pennsylvania, January 1981, pp. 1-34.

18. H. Z. Harmathy and W. W. Stanzak, "Elevated-Temperature Tensile and Creep Properties of Some Structural and Prestressing Steels," Fire Test Performance, ASTM STP 464, American Society for Testing and Materials, Philadelphia, Pennsylvania, 1970, pp. 186-208.

19. "A 36 Steel," Structural Alloys Handbook, 1989 Edition, Volume 3, Battelle, Columbus, Ohio, pp. 1-17.

20. T. V. Galambos and M. K. Ravindra, "Properties of Steel for Use in LRFD," Journal of the Structural Division, ASCE, Vol. 104, No. ST9, September 1978, pp. 1459-1468.

22. Manual of Steel Construction Allowable Stress Design, 9th ed., American Institute of Steel Construction, Inc., Chicago, Illinois, 1989.

97. "Specification for Structural Steel," SA-36/SA-36M, ASME Boiler and Pressure Vessel Code, Section II, Part A - Ferrous Material Specifications, July 1, 1992, pp. 111-114.

98. "Rules for Construction of Nuclear Power Plant Components," ASME Boiler and Pressure Vessel Code, Section III, Division 1 - Subsection NE, Class MC Components, American Society of Mechanical Engineers, New York, New York, July 1, 1992.

99. "Rules for Construction of Nuclear Power Plant Components," ASME Boiler and Pressure Vessel Code, Section III, Division 2, Code for Concrete Reactor Vessels and Containments, Subsection CC, Concrete Containments (Prestressed or Reinforced), American Society of Mechanical Engineers, New York, New York, July 1, 1992.

100. "Standard Specification for Structural Steel," ASTM Designation: A 36/A 36M-90, 1991 Annual Book of ASTM Standards, Volume 01.04, American Society for Testing and Materials, Philadelphia, Pennsylvania, pp. 108-110.

101. "Specification for General Requirements for Rolled Steel Plates, Shapes, Sheet Piling, and Bars for Structural Use," SA-6/SA-6M, ASME Boiler and Pressure Vessel Code, Section II, Part A - Ferrous Material Specifications, July 1, 1992, pp. 1-55. 
Update Package Number 5 Revision Control code 0.0 quality Level B

\section{Reference Documentation}

102. "Specification for General Requirements for Rolled Steel Plates, Shapes, Sheet Piling, and Bars for Structural Use," ASTM Designation: A 6/A 6M-90a, 1991 Annual Book of ASTM Standards, Volume 01.04, American Society for Testing and Materials, Philadelphia, Pennsylvania, pp. 13-63.

103. "Materials," ASME Boiler and Pressure Vessel Code, Section II, Part D - Properties, American Society of Mechanical Engineers, New York, New York, July 1, 1992.

104. "Standard Practice for Numbering Metals and Alloys (UNS)," ASTM Designation: E 527-83, 1990 Annual Book of ASTM Standards, Volume 01.04, American Society for Testing and Materials, Philadelphia, Pennsylvania, pp. 620-625.

113. "A-537 Steel," Structural Alloys Handbook, 1989 Edition, Volume 3, Battelle, Columbus, Ohio, pp. 1-12. 


\section{INTERNAL DISTRIBUTION}
1. W. G. Craddick
2. R. G. Gilliland
3. H. Jones
4-11. D. J. Naus
12. D. G. O'Connor
13-19. C. B. Oland

20. C. E. Pugh

21. J. O. Stiegler

22. ORNL Patent Section

23. Central Research Library

24. Document Reference Section

25-26. Laboratory Records

27. Laboratory Records, ORNL-RC

\section{EXTERNAL DISTRIBUTION}

28. L. C. Shao, Division of Engineering Technology, Office of Nuclear Regulatory Research, Nuclear Regulatory Commission, Washington, DC 20555-0001

29. J. W. Craig, Division of Engineering Technology, Office of Nuclear Regulatory Research, Nuclear Regulatory Commission, Washington, DC 20555-0001

30. J. F. Costello, Division of Engineering Technology, Office of Nuclear Regulatory Research, Nuclear Regulatory Commission, Washington, DC 20555-0001

31. A. Murphy, Division of Engineering Technology, Office of Nuclear Regulatory Research, Nuclear Regulatory Commission, Washington, DC 20555-0001

32. H. Graves, Division of Engineering Technology, Office of Nuclear Regulatory Research, Nuclear Regulatory Commission, Washington, DC 20555-0001

33-45. W. Norris, Division of Engineering Technology, Office of Nuclear Regulatory Research, Nuclear Regulatory Commission, Washington, DC 20555-0001

46. J. Philip, Division of Regulatory Applications, Office of Nuclear Regulatory Research, Nuclear Regulatory Commission, Washington, DC 20555-0001

47. M.E. Mayfield, Division of Engineering Technology, Office of Nuclear Regulatory Research, Nuclear Regulatory Commission, Washington, DC 20555-0001

48. J. P. Vora, Division of Engineering Technology, Office of Nuclear Regulatory Research, Nuclear Regulatory Commission, Washington, DC 20555-0001

49. H. G. Ashar, Division of Engineering, Office of Nuclear Reactor Regulation, Nuclear Regulatory Commission, Washington, DC 20555-0001

50. G. Bagchi, Division of Engineering, Office of Nuclear Reactor Regulation, Nuclear Regulatory Commission, Washington, DC 20555-0001

51. D. C. Jeng, Division of Engineering, Office of Nuclear Reactor Regulation, Nuclear Regulatory Commission, Washington, DC 20555-0001

52. R. E. Shewmaker, Office of Nuclear Materials Safety \& Safeguards, Low-Level Waste Management Branch, Nuclear Regulatory Commission, Washington, DC 20555-0001

53. C. J. Hookham, 2902 Eisenhower, Ann Arbor, MI 48108

54. B. Ellingwood, Professor of Civil Engineering, The Johns Hopkins University, 109 Latrobe Hall, 3400 North Charles St., Baltimore, MD 21218-2699

55. J. R. Clifton, National Institute of Standards of Technology, Building 226, Room B-348, Gaithersburg, MD 20899

56. D. R. Eggett, Commonwealth Edison, 1400 Opus Place, Suite 500, Downers Grove, Il 60515 
57. K. R. Lauer, Professor of Civil Engineering, University of Notre Dame, Notre Dame, IN 46556-0767

58. M. K. Ravindra, EQE International, 44 Montgomery Street, Suite 3200, San Francisco, CA 94104-4805

59. J. W. Reed, Jack R. Benjamin and Assoc., 444 Castro St., Suite 501, Mountain View, CA 94041

60. W. L. Gamble, Professor of Civil Engineering, University of Illinois, 3122 Newmark Civil Engineering Laboratory, 205 N. Mathews, Urbana, IL 61801

61. R. W. Seidensticker, Argonne National Laboratory, 9700 S. Cass Avenue, Argonne, IL 60439

62. T. C. Liu, Chief, Materials Engineering Section, Headquarters, U.S. Army Corps of Engineers, 20 Massachusetts Ave., NW, HQUSACE (CECW-EG), Washington, DC 20314

63. J. Carey, Electric Power Research Institute, 3412 Hillview Avenue, Palo Alto, CA 94304

64. H. W. Massie, Jr., Defense Nuclear Facilities Safety Board, 625 Indiana Ave., NW, Suite 700, Washington, DC 20004

65. G. Frohnsdorff, National Institute of Standards of Technology, Building 226, Room B-368, Gaithersburg, MD 20899

66. K. N. Chao, Consumers Power Co., 1945 West Parnell Road, Jackson, MI 49201

67. Office of Assistant Manager for Energy Research and Development, DOE-OR, Oak Ridge, TN 37831

68-69. Office of Scientific and Technical Information, P.O. Box 62, Oak Ridge, TN 37831 


\section{RELEASE TO PUBLISH UNCLASSIFIED NRC CONTRACTOR, CONSULTANT, OR CONFERENCE PROCEEDINGS REPORTS}

(Prowe Tyos or Prim)

2. TITLE ANO SUBTITLE (Stest on tWII on thow on document)

Nuclear Power Plant Containment Metallic Pressure Boundary Materials and Plans for Collecting and Presenting Their

Properties
Obtain trom the Technied Publication Section on 492.7953

3. FIN OR GRANT NUMBER 100 not ikt DOE canance numow!

$\mathrm{J} 6043$

4. AUTHORS III mon then thre, neme tirs numer followes or "and amans")

C. B. Oland (16)

Oak Ridge National Laboratory P.0. Box 2009, Bldg. 9204-1

X A. TECHNICAL REPORT
$\square$ FORMAL
X LeTtER REPORT

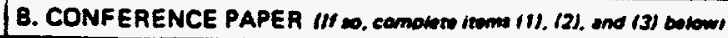

(1) TITLE OF CONFERENCE PAPER:

(2) DATE(S) OF CONFERENCE:

(3) LOCATION OF CONFERENCE:

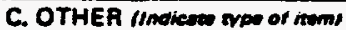

\section{NRC PROJECT MANAGEA ITYow or Print Neme" \\ W. E. Norris} TOFFICE/DIVISION TTELEPHONE TMAIL STOP TDATE

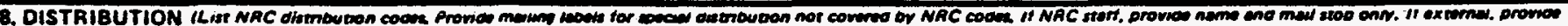

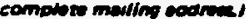

\begin{tabular}{|c|c|c|}
\hline \multirow{2}{*}{\multicolumn{2}{|c|}{$\mathbf{X}$}} & 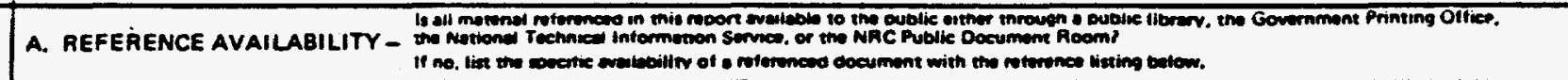 \\
\hline & & SPECIFIC AVAILABILITY \\
\hline & $\mathbf{X}$ & 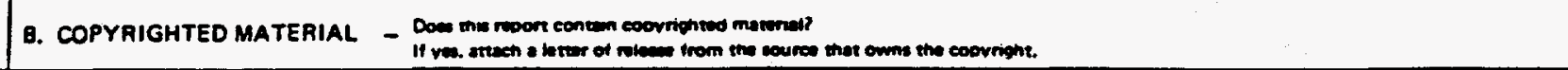 \\
\hline & $X$ & 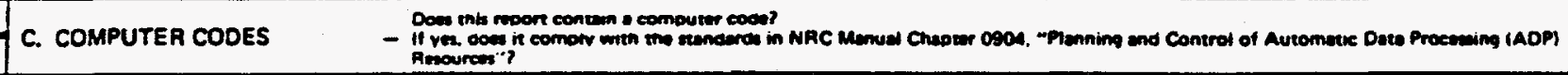 \\
\hline \multirow{2}{*}{\multicolumn{2}{|c|}{$\mathbf{X}$}} & 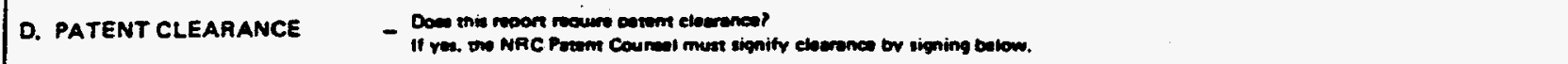 \\
\hline & & NAC PATENT COUNSEL IT YPO or Prime Mame' SIGNATUAE \\
\hline & $\mathbf{X}$ & 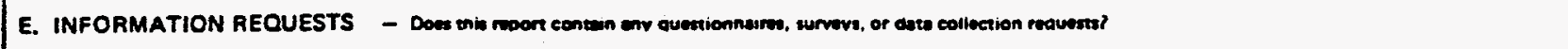 \\
\hline & $\mathbf{X}$ & 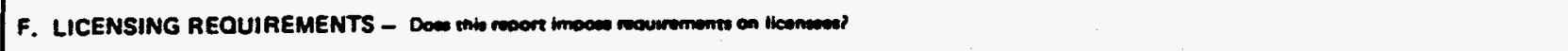 \\
\hline \multicolumn{3}{|r|}{ 10. AUTHORIZATION } \\
\hline \multicolumn{3}{|r|}{ 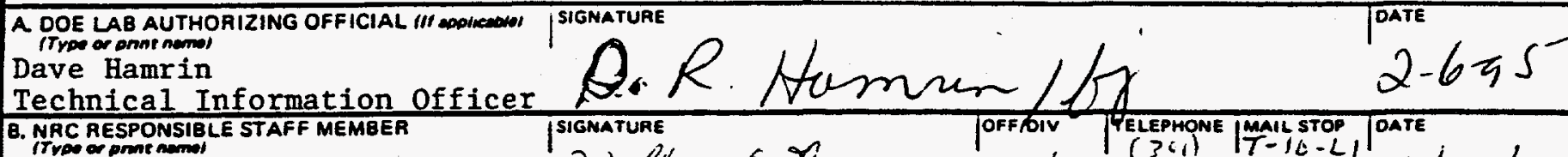 } \\
\hline 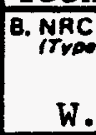 & E. & 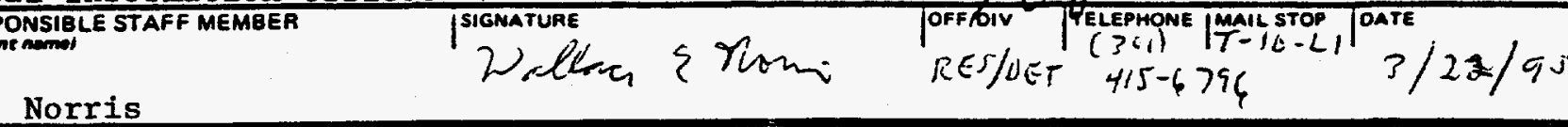 \\
\hline
\end{tabular}

